DOE/NV/11432-163

UC-702

\title{
THE 1993 BASELINE BIOLOGICAL STUDIES AND PROPOSED MONITORING PLAN FOR THE DEVICE ASSEMBLY FACILITY AT THE NEVADA TEST SITE
}

By

Bruce D. Woodward

Richard B. Hunter

Paul D. Greger

Mary B. Saethre

February 1995

Work Performed Under Contract No. DE-ACO8-94NV11432

Prepared for the

United States Department of Energy

Nevada Operations Office

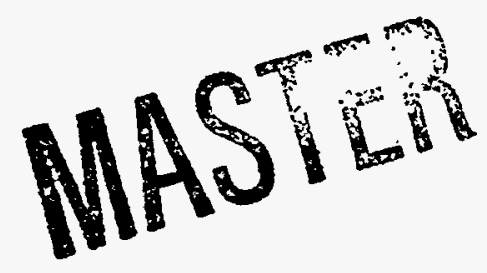

Prepared by

Reynolds Electrical \& Engineering Co., Inc

Post Office Box 98521

Las Vegas, Nevada 89193-8521 


\section{DISCLAIMER}

This report was prepared as an account of work sponsored by an agency of the United States Government. Neither the United States Government nor any agency thereof, nor any of their employees, make any warranty, express or implied, or assumes any legal liability or responsibility for the accuracy, completeness, or usefulness of any information, apparatus, product, or process disclosed, or represents that its use would not infringe privately owned rights. Reference herein to any specific commercial product, process, or service by trade name, trademark, manufacturer, or otherwise does not necessarily constitute or imply its endorsement, recommendation, or favoring by the United States Government or any agency thereof. The views and opinions of authors expressed herein do not necessarily state or reflect those of the United States Government or any agency thereof. 


\section{DISCLAIMER}

Portions of this document may be illegible in electronic image products. Images are produced from the best available original document. 
EXECUTIVE SUMMARY ...................

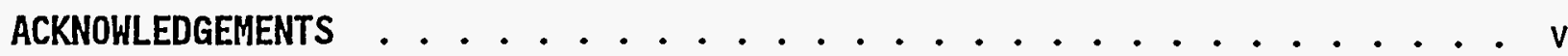

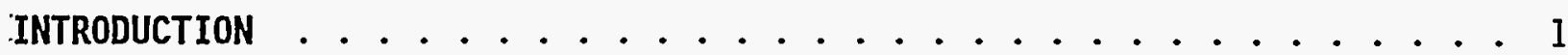

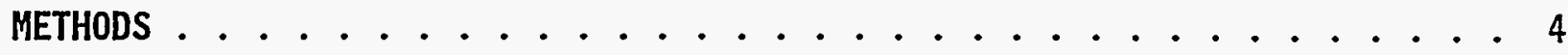

EPHEMERAL PLANTS .................. 4

Standard Ephemeral Technique .............. 6

$\log _{10}$ Ephemeral Technique . . . . . . . . . . . . 7

$\log _{2}$ Ephemeral Technique ............. . . 7

PERENNIAL PLANTS .................. 8

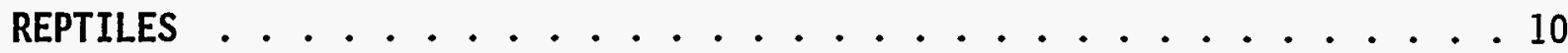

Roadside Studies .................. 11

DAF Diversion Ditch Studies ............... 13

Lizard Transects .................. . . . 13

DAF Timed Surveys .................. . . 14

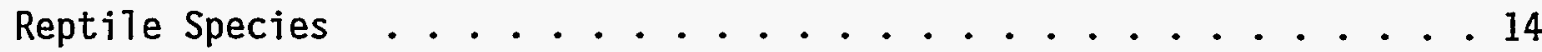

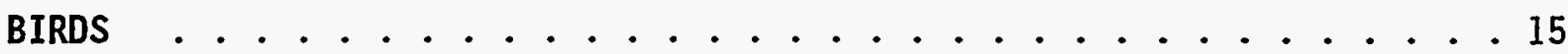

Sewage Pond Effects ................... . . 15

Natural Habitat Sampling ................ . 16

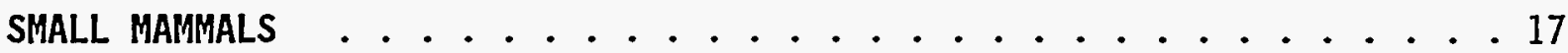

Rodent Presence and Abundance .............. 18

Presence of 0ther Species ............... . . 20

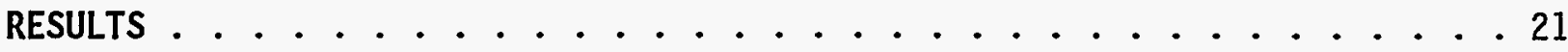

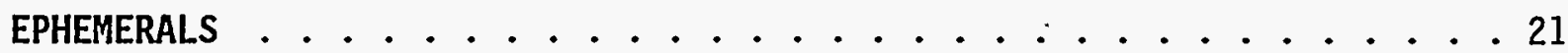

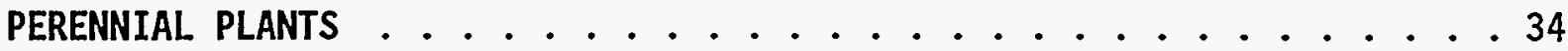

Effects of the DAF on Perennial PIants ............ . 37

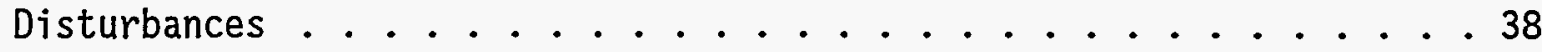

Sensitive Perennial PTants ................ . . 40

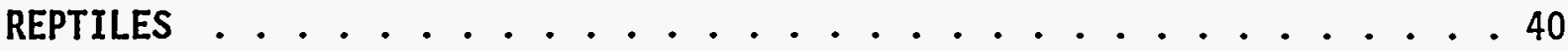

Roadside Studies .................. . . 40

Spring Samples ................... 40

Summer Samples ..................... 41

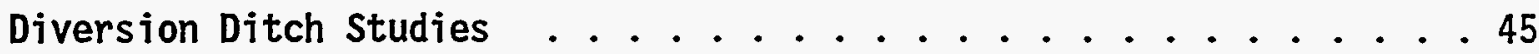

Spring Samples................... 45

Summer Samples ................. . . . 47

DAF Lizard Transects . . . . . . . . . . . . . . 49

DAF Timed Surveys ................. . . 49

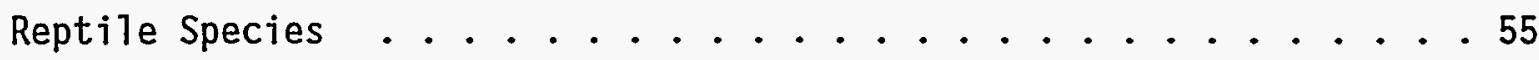


BIRDS ..............................55

Sewage Pond vs. Naturat Area ................. 55

Other Migrant Use ...................... 63

Ravens ........................... 63

Bird Species on Undisturbed Habitats . . . . . . . . . . . 64

Sensitive Bird Species .................... . 65

MAMMALS

Rodents Present ..................... 66

Other Mammat Species .................... . 67

Abundance and Roadside Effects ................ 68

Trap Type ........................ 72

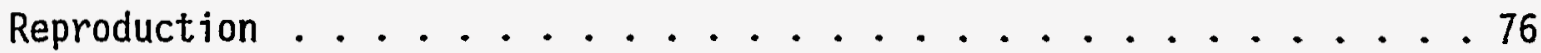

Bat Species ...................... . . 81

DISCUSSION . . . . . . . . . . . . . . . . . . 82

EPHEMERALS ....................... 82

Ephemeral Techniques ................. 82

Ephemeral Poputations in 1993 . . . . . . . . . . . 83

Effects of Disturbances on Ephemeral Populations . . . . . . . 86

PERENNIAL PLANTS ..................... 87

SENSTIVE PLANTS ..................... 89

REPTILES . . . . . . . . . . . . . . . . . . 89

Potential Effects of the DAF on Reptiles........... 92

BIRD ............................ 93

MAMMAL .......................... 95

Trap Type ......................... . . 96

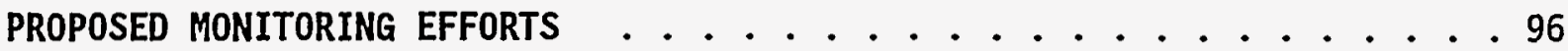

EXPECTED DAF EFFECTS AND FUTURE MONITORING OF EPHEMERALS . . . . . 96

PERENNIAL PLANTS ....................... 98

SENSITIVE PLANTS . . . . . . . . . . . . . . . . 100

REPTILES . . . . . . . . . . . . . . . . . 100

BIRDS ...................... 103

MAMMALS ....................... 104

REFERENCES .......................... 106

APPENDIX A . . . . . . . . . . . . . . . . 116

APPENDIX B ........................ 119

APPENDIX C . . . . . . . . . . . . . . . . 122

APPENDIX D . . . . . . . . . . . . . . . . 126 


\section{EXECUTIVE SUMMARY}

This report contains baseline data and recommendations for future monitoring of plants and animals near the new Device Assembly Facility (DAF) on the Nevada Test Site (NTS). The facility is a large structure designed for safely assembling nuclear weapons.

Baseline data was collected in 1993, prior to the scheduled beginning of DAF operations in early 1995. Studies were not performed prior to construction and part of the task of monitoring operational effects will be to distinguish those effects from the extensive disturbance effects resulting from construction. Baseline information on species abundances and distributions was collected on ephemeral and perennial plants, mammals, reptiles, and birds in the desert ecosystems within three kilometers $(\mathrm{km})$ of the DAF. Particular attention was paid to effects of selected disturbances, such as the paved road, sewage pond, and the flood-control dike, associated with the facility. Radiological monitoring of areas surrounding the DAF is not included in this report.

The ephemeral plant community was surprisingly diverse, containing more species than most NTS study sites. Even some scraped areas had 50 species, an unusual number not expected to persist. Several introduced annual weeds were associated with the roads and scraped areas. Disturbance had less effect on the perennial plants, although areas near the DAF had fewer shrubs and a higher ratio of live to dead shrubs, both attributable to extensive removal of shrubs during construction. Dominant plants were the Joshua tree (Yucca brevifolia) and creosote bush (Larrea tridentata). A relatively high proportion of dead shrubs was attributable to recent drought.

The sma11 mammal community included 9 species. Merriam's kangaroo rat was the most numerous species south of the DAF, while the long-tailed pocket mouse was most common north of the DAF.

Reptile species included occasional desert tortoises, but lizards were by far the most abundant reptiles. The common side-blotched lizard was excluded from cleared areas, but was present in summer at increased densities at the margin of the paved access road. One species (Callisaurus draconoides) was dominant in the flood-dike ditch and uncommon elsewhere. 
The DAF sewage ponds were used extensively by migratory birds and species nesting near the DAF. The ponds were also an area of heavy bird predation. Ravens made only occasional use of the sewage ponds.

One federally listed threatened species (Mojave desert tortoise, Gopherus agassizii) and two candidate species (loggerhead shrike, Lanius ludovicianus, and chuckwal1a, Sauromalus obesus) were observed in the vicinity of the DAF. The candidate species are both category 2 at this time.

These pre-operational baseline measurements will allow assessment of future operational effects on the ecosystem surrounding the DAF and wi11 help distinguish construction effects from operational effects. 


\section{ACKNOWLEDGEMENTS}

Credit to the following: J. A. Alexander, B. P. Edwards, J. V. Hopkin, D. A. Kline, D. W. O'Sullivan, K. A. Seward, and M. 0. Weaver. Al so

F. D. Ferate, B. Kinnison and L. S. Sygitowicz (aT1 ASD) and E. Rucker and the personnel at the DAF. Work performed under contract \#DE-AC08-94NV11432. Scientific collection permits were provided by the State of Nevada Department of Wildlife (S 6404 and S 9022) and the U.S. Fish and Wildlife Service (RPT-744522). 


\section{INTRODUCTION}

This report describes the first year's work performed near the DAF in northwestern Frenchman Flat on the Nevada Test Site (NTS). BECAMP began DAF work in 1993 by developing study techniques, setting up permanent plots, and initiating biological studies. BECAMP sampling efforts focused on ephemeral and perennial plants, birds, mammals, and reptiles. The first year's work was designed to determine patterns of species' distributions and abundances prior to operation of the DAF. These baseline studies ask what current patterns exist in this area. This information is important to understand and document changes that may emerge after DAF operations begin. Two types of patterns were looked for, those emanating from natural causes (e.g., changes associated with shifts in position along the slope), and those associated with nonnuclear DAF operations (such as construction, or use of roads or the physical plant). Separation of these factors was somewhat problematic as baseline studies were not begun until after a considerable amount of construction had occurred. This prevented study of preconstruction conditions, and made selection of appropriate control sites somewhat subjective. Given these results we developed methods to detect effects of future DAF operations on plants and animals.

The NTS is a $3479 \mathrm{~km}^{2}$ U.S. Department of Energy (DOE) site located $110 \mathrm{~km}$ north of Las Vegas. It consists of playa valleys separated by mesas and mountains with valley bottoms at 900 to $1500 \mathrm{~m}$ and mesa and mountain tops at 1700 to $2200 \mathrm{~m}$. The NTS is located across the transition zone between the Mojave (Larrea-Ambrosia) and Great Basin (Artemisia) desert communities. These deserts differ in vegetation, soil type, and elevation. While typical habitats of both deserts occur on the NTS, aspects of each are present in the transition zone. Plant communities on the NTS (A17red et al. 1963; Beatley 1976; 0'Farre11 and Emery 1976) support biotic communities that typify each desert, with mixing occurring in transitional areas (Jorgensen and Hayward 1965).

The DAF is located in habitat most like the Mojave but also near the transition zone on an alluvial fan in northwestern Frenchman $\mathrm{Flat}, 27 \mathrm{~km}$ north of Mercury, the main entrance to the NTS. The area is characterized by gentle slopes cut by shallow arroyos 1 to $3 \mathrm{~m}$ deep with shallow soils and high rock content at the surface. The DAF buildings are located two to three $\mathrm{km}$ south and east of steep rocky hillsides and several $\mathrm{km}$ west of Frenchman Lake. 


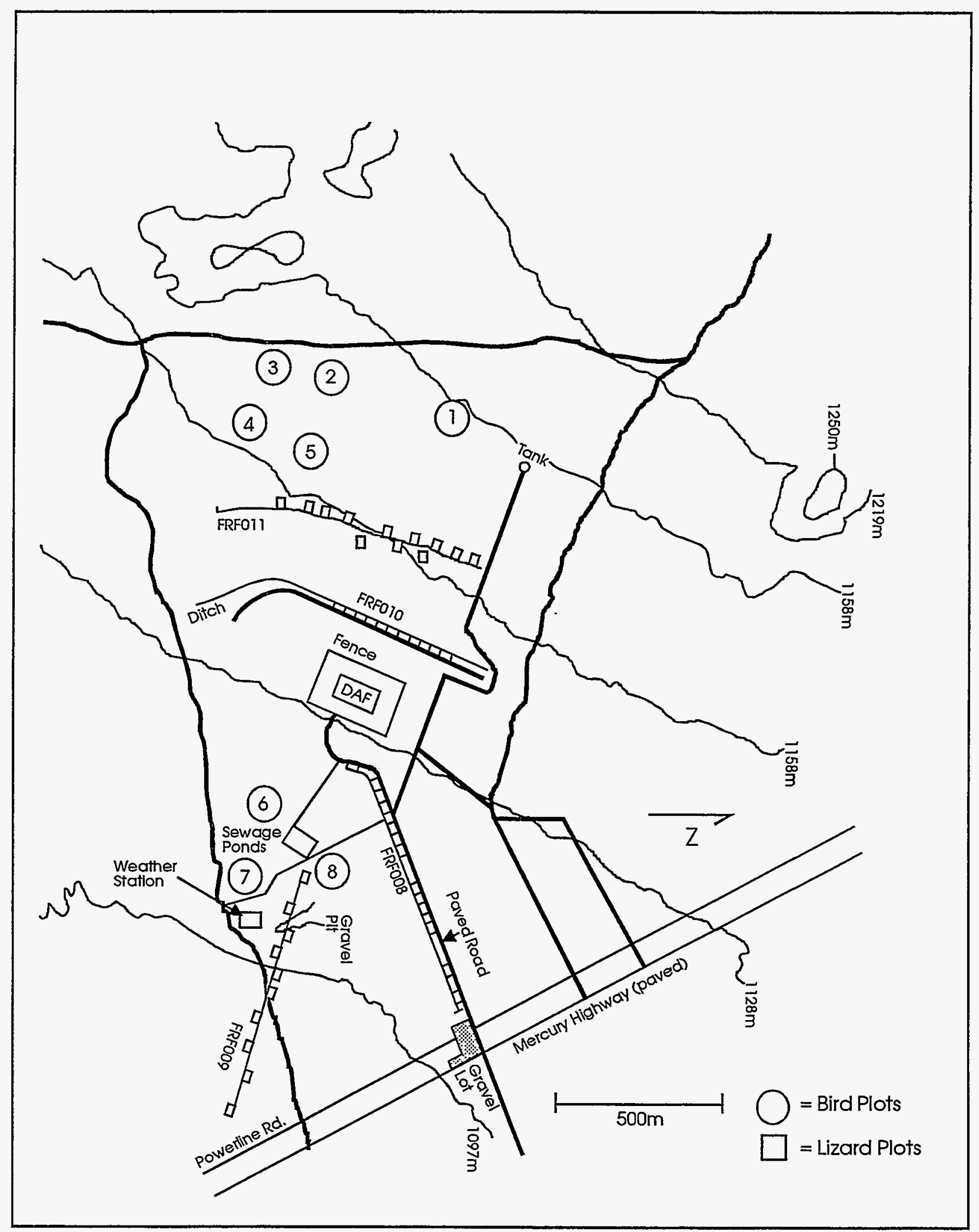

Figure 1 - Physical Tayout in the vicinity of the DAF buildings showing structures with important potential ecological consequences, and the distribution of BECAMP study areas. 


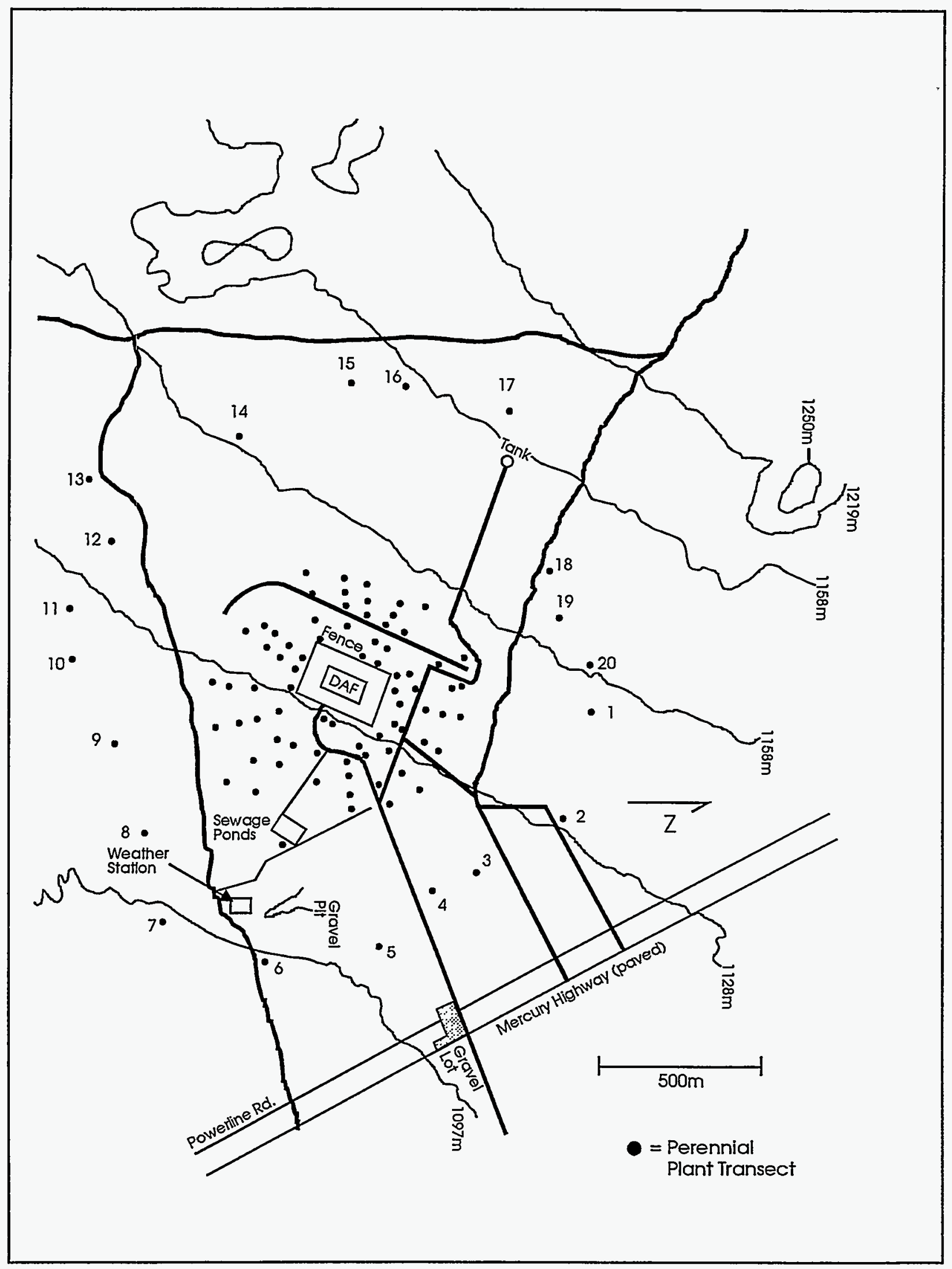

Figure 2 - Distribution of plant sampling area near the DAF. 
Sampling was concentrated on gentle slopes within $3 \mathrm{~km}$ of the buildings, although some sampling was done in the rocky foothills. The buildings were still under construction and in pre-operational phase during spring and summer surveys in 1993. As such, disturbances were those associated with construction of any large building project: trampling, grading, road construction and road use, and human use of the site.

The DAF complex is a cluster of buildings where final phases of nuclear weapon assembly is to occur. During DAF construction, a sizeable area surrounding the buildings was cleared, graveled, and used as a parking lot. The main building is also surrounded by two chain link fences and ringed by powerfut lights on tall poles. Several DAF support facilities have potential ecological impacts including a paved access road, power poles, a water storage tank, a diversion ditch uphill of the buildings, and sewage evaporation ponds (Figures 1, 2). Although there will be no release of radioactive material during normal operations, the DAF can potentially influence the environment through accidental release of radioactive material, or through nonnuclear effects of DAF operation (Table 1).

\section{METHODS}

Annual and perennial plants, birds, large mammals, small mammals, and reptiles were studied at the DAF. Both common species and species of special concern to federal or state agencies were studied. In the following sections each of these groups is discussed in turn.

\section{EPHEMERAL PLANTS}

Ephemeral plants (annuals) play an important role in desert systems (Inouye 1991). Their stems, leaves, and seeds serve as forage for mammals, nesting material for birds and mammals, and as a major fuel load for fires. Their seeds are an important nutrient source for birds, mammals and ants, even long after vegetative parts of the plant have died (Reichman 1991). In disturbed areas, they are commonly the major component of the vegetation - and thus the local energy source for the system. BECAMP's studies were designed to document ephemeral populations in undisturbed areas of Frenchman Flat, establish baseline values for future comparisons, examine effects of roads or construction activity on ephemeral populations, and increase the efficiency of the sampling approach. Efficient sampling is important at the DAF because DAF 
effects might emanate in any direction from it, requiring numerous baseline samples to be collected.

Table 1. Nonnuclear effects of DAF operations and their potential ecological consequences.

\begin{tabular}{|c|c|}
\hline 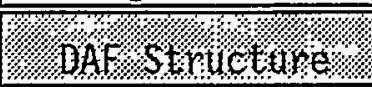 & 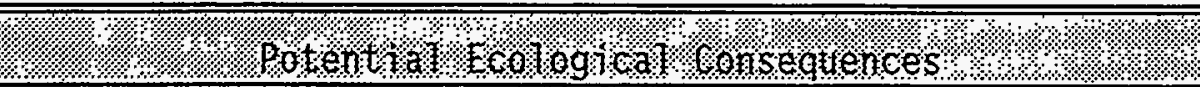 \\
\hline $\begin{array}{l}\text { 1. Cleared areas } \\
\text { (gravel roads, } \\
\text { parking lots, } \\
\text { ditch) }\end{array}$ & $\begin{array}{l}\text { Removes plants, eliminates habitat for animals, creates } \\
\text { habitat for weedy species. Dispersal of seeds or young } \\
\text { animals from this area may affect species composition or } \\
\text { relative abundance in surrounding areas. Clearings may } \\
\text { restrict movement or limit dispersal and contribute to } \\
\text { population fragmentation of some species. }\end{array}$ \\
\hline 2. Roads & $\begin{array}{l}\text { All functions listed under number } 1 \text {; potentially } \\
\text { increases mortality of some animals via road kills; may } \\
\text { increase predator/scavenger densities which may be } \\
\text { important for tortoise mortality; influences water } \\
\text { runoff and use, which may influence species composition } \\
\text { along the road. }\end{array}$ \\
\hline $\begin{array}{l}\text { 3. Flood control } \\
\text { ditch }\end{array}$ & $\begin{array}{l}\text { A11 functions } 1 \text { isted under number } 1 \text {; may influence soil } \\
\text { water potential and thus influence species } \\
\text { distributions. }\end{array}$ \\
\hline 4. Fence & $\begin{array}{l}\text { May restrict dispersal leading to concentration of some } \\
\text { species along fence, some animals may get caught in } \\
\text { fence and die. }\end{array}$ \\
\hline 5. Trash & $\begin{array}{l}\text { May create habitat, increasing local densities of some } \\
\text { species. }\end{array}$ \\
\hline $\begin{array}{l}\text { 6. Building, } \\
\text { especially guard } \\
\text { towers }\end{array}$ & $\begin{array}{l}\text { May create new habitat for some species, most notably } \\
\text { roost, perch or nest sites for birds and mammals. Birds } \\
\text { may collide with towers and be killed or injured. }\end{array}$ \\
\hline 7. Power poles & A71 functions 7 isted under number 6 . \\
\hline $\begin{array}{l}\text { 8. Lights and } \\
\text { 7ight poles }\end{array}$ & $\begin{array}{l}\text { A17 functions listed under number } 6 \text {; may attract } \\
\text { insects, and birds, bats, and lizards that feed on } \\
\text { insects. }\end{array}$ \\
\hline $\begin{array}{l}\text { 9. Sewage } \\
\text { settling ponds }\end{array}$ & $\begin{array}{l}\text { A11 functions } 1 \text { isted under number } 1 \text {; increases water } \\
\text { availability which allows species with higher water } \\
\text { requirements to use this area. }\end{array}$ \\
\hline
\end{tabular}


Several ephemeral sampling techniques were used near the DAF to evaluate the speed of data collection and quality of results. Parameters varied across techniques included dispersion of sampled areas and method of density estimation (total count, estimates to base 10 , or estimates to base 2). In addition to technique evaluation, plots were also arranged to evaluate the effect of a graveled area (DAF 1, 2, Table 2), a paved road (DAF 3, 4, Table 2) or a dirt road (DAF 5, 6, Table 2) on ephemera7s.

Species presence, their densities and total production (biomass), relative dominance and evidence for changing dominance were parameters desired from al 1 locations. Along the scraped verges of the paved road leading to the DAF there were dense concentrations of one ephemeral species (Eriogonum deflexum), and lower densities of some introduced species (particularly the small grass Schismus arabicus and the toxic weed Halogeton glomeratus). In this area a study was initiated to characterize the distance to which these species' populations had already increased by construction and operation of the paved road. This study gives an idea of how far into undisturbed vegetation effects of the extensive disturbances around the DAF might eventually affect ephemeral populations.

An important goal was to find a way to reduce the time needed to sample ephemeral populations. Because DAF operational effects are expected to be stronger near the facilities, but the direction of effects is not predictable, it is desirable to look for changes in many directions. However, current techniques for characterizing ephemeral populations are time consuming, and early May of most years. Characterizing many areas surrounding the DAF was considered time available for sampling is limited to several weeks in late April and early May of most years. Characterizing many areas surrounding the DAF was considered desirable, but not practical, in the absence of more rapid techniques.

\section{Standard Ephemeral Technique}

BECAMP's standard ephemeral sampling procedure (AAHBCD.02.02 revised 5/11/92) was used on sites DAF1 and DAF2 (Table 2) to characterize ephemeral populations in disturbed and undisturbed areas near the DAF. Briefly, it involved laying out a $50-m$ tape in a random location, then harvesting all ephemeral plants from twenty random $0.025 \mathrm{~m}^{2}$ quadrats placed along the tape. Harvested plants were separated by species, dried, weighed, and identified to determine population parameters. Other species not seen in the 20 quadrats but 
present within one meter of the tape (100 $\mathrm{m}^{2}$ area) or within ten meters of the tape $\left(1000 \mathrm{~m}^{2}\right)$ were recorded. This allowed calculation of densities and biomass for common species, and determination of presence/absence and a rough limit of density for the rarer species. A t-test was used to compare density, biomass, or surface characteristics between disturbed and undisturbed areas.

A sample was taken of each species when first encountered, to allow identification or confirmation of identity by comparison to herbarium specimens. Taxonomy of plant species followed Munz (1974), with synonymy following Kartesz and Kartesz (1980).

At a randomly chosen spot (DAF3, Table 2) on the paved road a modification of the standard technique was used. Only 10 quadrats were harvested, and as the area was not wide enough to sample the $1000 \mathrm{~m}^{2}$ area, only the $100 \mathrm{~m}^{2}$ area was censused. Samples were collected in the center of the scraped area on the south-facing road shoulder, one $m$ into the undisturbed vegetation next to the shoulder, and again $50 \mathrm{~m}$ south of the pavement edge, in undisturbed vegetation. One way analysis of variance was used to compare parameters among the three areas.

\section{$\log _{10}$ Ephemeral Technique}

To determine if road effects dissipated with distance, a 50-meter tape was 7aid perpendicular to the paved road (starting at the edge of the pavement) at ten randomly selected locations (DAF4, Table 2). Ephemeral density was estimated for each species in a one $\mathrm{m}^{2}$ area at each meter from 0 to 12 , and at $15,20,25,30,35,40,45$, and 50 meters from the road. In each square meter a count of zero to four members of a species was given a log-density of 0,5 to 49 (estimated) was given a 1,50 to 499 a 2, 500 to 4999 a 3 , and $>5000$ a 4. Oneway ANOVA was used to compare mean $\log _{10}$ densities of species on the ten roadside scraped areas with those for the ten undisturbed sections.

\section{$\log _{2}$ Ephemera] Technique}

A set of nested quadrats was placed at a randomly chosen point along a 50 meter tape in the middle of the dirt road to the water tank (DAF5, Table 2) and a control area 50 meter east of that road (DAF6, Table 2). Each quadrat was roughly twice the size of the next-innermost. Embroidery hoops of areas $0.0327,0.0726$, and $0.299 \mathrm{~m}^{2}$ were surrounded by rectangular areas of $0.5,1.0$, $2,4,8,16,32,64,128,256$ and $400 \mathrm{~m}^{2}$ laid along a 50-meter surveyors' 
tape. Within each area species numbers were counted or estimated in powers of two with a technique similar to that of McAuliffe (1990). In addition, ten individuals of the most common species were harvested, dried and weighed to determine approximate biomass for their populations. The technique was intended to improve speed of population characterization.

Means, standard errors, and ANOVA were calculated with the program RSI (BBN Software). t-tests were done by hand following $\operatorname{Zar}$ (1984) or with MINITAB (Minitab, Inc.).

\begin{tabular}{|c|c|c|}
\hline 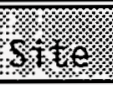 & 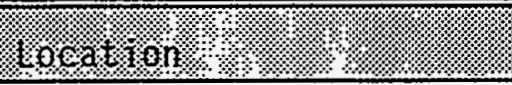 & 0esctivtron: \\
\hline DAF1 & $36^{\circ} 54.02^{\prime} \mathrm{N} ; 116^{\circ} 3.03^{\prime} \mathrm{W}$ & Undisturbed, $-50 \mathrm{~m} \mathrm{~N}$ of dike/ditch \\
\hline DAF2 & $36^{\circ} 53.70^{\circ} \mathrm{N} ; 116^{\circ} 2.89^{\prime} \mathrm{W}$ & Scraped, graveled area W of DAF \\
\hline DAF3 & $36^{\circ} 54.05^{\prime} \mathrm{N} ; 116^{\circ} 2.18^{\prime} \mathrm{W}$ & South side of paved access road \\
\hline DAF4 & $36^{\circ} 53.96^{\circ} \mathrm{N} ; 116^{\circ} 2.47^{\prime} \mathrm{W}$ & South edge of paved access road \\
\hline DAF5 & $36^{\circ} 54.39^{\circ} \mathrm{N} ; 116^{\circ} 3.55^{\prime} \mathrm{W}$ & Center of dirt road to water tank \\
\hline DAF6 & $36^{\circ} 54.31^{\prime} \mathrm{N}: 116^{\circ} 3.33^{\circ} \mathrm{W}$ & $50 \mathrm{~m}$ East of dirt road to water tank \\
\hline
\end{tabular}

\section{PERENNIAL PLANTS}

The primary goal of perennial plant measurements was to document perennial plant germination, death, and growth. A secondary goal was to determine preoperational effects of construction disturbance on perennial plant communities surrounding the DAF.

Perennial plants were measured on five sets of 20 plots arranged in concentric bands around the DAF (Fig. 2). The closest set was located between the outer security fence surrounding the DAF buildings and $300 \mathrm{~m}$ from the front door of the DAF. Other sets were located between 300 and $400 \mathrm{~m}, 400$ and $500 \mathrm{~m}, 500$ and $600 \mathrm{~m}$, and 1000 and $1500 \mathrm{~m}$ from the front door. The outer group was considered a control, representing a subjective balance between the distance where the DAF might exert an influence, and a distance where vegetation would no longer resemble the plant community surrounding the DAF buildings. Five distances were randomly chosen at each of 20 random angles in $18^{\circ}$ arcs, 
resulting in 100 plots surrounding the DAF. Distances and directions within $600 \mathrm{~m}$ of the DAF were measured with a Rolatape $1000 \mathrm{~m}$ Measure Master ${ }^{\circledR}$ and a hand-held compass. Plot locations beyond $1000 \mathrm{~m}$ were determined with a Magellan ${ }^{\circledR}$ GPS (global positioning system) unit. Each plot was marked with two metal stakes five meters apart oriented North-South, with a white polyvinylchloride (PVC) pipe placed on the southern post and marked with a brass tag labelled 1-1 to 20-5. Plots located on dirt roadways were marked with $15 \mathrm{~cm}$ by $2 \mathrm{~cm}$ aluminum stakes pounded in and bent over flush with the ground.

To measure plants, a fiberglass tape was strung between the two plot markers, and each perennial $\mathrm{pl}$ ant whose base was within $1 \mathrm{~m}$ of the tape was examined. Its size (height, greatest width, and width perpendicular to the greatest) was measured to the nearest $\mathrm{cm}$; species, reproductive state (production of flower buds only, flowers, or fruit this year), and percent dead (approximate \% of canopy) were recorded. We recorded each plant's location (the center of the base) to the nearest centimeter perpendicular to the tape, and to the nearest decimeter mark along the tape. All living and dead plants within the ten $\mathrm{m}^{2}$ area were included. Plant species with numerous individuals were counted within $1 \mathrm{~m}^{2}$ areas and an individual of median size was measured to characterize the group.

Because some dominant plant species were too dispersed to fall regularly within small plots, individual $\mathrm{plants}$ of the dominant species were also marked and measured at most of the 100 plot locations surrounding the DAF. The individual Yucca brevifolia (Joshua tree), Larrea tridentata (creosotebush), and Ephedra nevadensis (Nevada Mormon tea) nearest to the southern post of each perennial plot was measured, along with its distance and angle (degrees $E$ of $\mathrm{N}$ from the post), using a hand-held compass and a fiberglass surveyor's tape. Only live plants within 25 meters of the post were selected, with some exceptions where individual Joshua trees were easily seen just outside that limit.

Biomass (oven dry weight) was estimated from plant size using linear regressions on volume determined in the 1970's for the NTS (Hunter and Medica 1989). Biomass of Yucca brevifolia was estimated from size-class/weight data for trees from Area 11 on the NTS (Tueller and Bostick, unpublished manuscript). Biomass of dead plants was not determined. 
Analysis of variance, Chi-square, and means and standard errors were calculated in RS1 (BBN Software, Inc.). Kruskal-Wallis tests were done with MINITAB (Minitab, Inc.). Comparisons of plant characteristics were made across the 5 concentric rings around the DAF to determine if perennial vegetation changed with distance from it.

Finally, because disturbance has such a major effect on the vegetation, the frequency of disturbance was examined near the DAF. To do this a Rolatape Measure Master ${ }^{\circledR}$ was used to measure distance to the nearest disturbance from the south post of each $\mathrm{p} 1$ ant transect. The nature of the disturbance and whether it appeared related to DAF construction were recorded for each of the 100 plots. Disturbances related to DAF utility lines, roads, or recent staging areas were considered DAF related. 07der disturbances, on which shrubs had generally regrown, could usually be related to structures or activities not related to the DAF. Relation of two disturbances to the DAF was ambiguous. Mean distance to disturbance was compared among the different plot-rings (Figure 2) using a Kruskal-Wall is test (Minitab; Minitab Inc.).

Taxonomy of plants follows Munz (1974) with names updated following Kartesz and Kartesz (1980). Common names of plants follow Scott and Wasser 1980.

\section{REPTILES}

Reptiles near the DAF include lizards, snakes, and desert tortoises. Lizards are widespread and common in deserts, including around the DAF (Tanner and Jorgensen 1963; Medica et a7. 1994). They also are primari7y diurna1, easily seen, and relatively easy to study. These attributes, combined with results (Turner and Medica 1977) suggesting lizards may be especially sensitive to radiation, make this a useful group for studying the potential effects of the DAF. BECAMP set up two sets of plots to examine DAF effects on lizards. One was designed to assess effects of the paved road into the DAF. The other set was designed to assess effects of a diversion ditch upslope of the DAF building complex. In addition, lizard transects were walked to assess the relative abundances of more mobile species that are poorly sampled by plot techniques. Timed searches were also performed to contrast lizard abundances in areas near and far from the DAF. Finally, from all these studies a reptile species 1 ist was generated for the DAF. Several techniques were used to determine the most suitable for detecting DAF effects in the future. 


\section{Roadside Studies}

Ten $20 \times 40 \mathrm{~m}$ lizard plots were placed along the southeastern edge of a paved road that runs from Mercury Highway to the main DAF building (Figure 1). Plots were placed in a uniform pattern 50 - $70 \mathrm{~m}$ apart. Several abandoned roads and parking areas adjoin this road. Plot locations were adjusted to avoid major cleared areas not characteristic of typical roadsides. Each plot was separated into eight, $10 \times 10 \mathrm{~m}$ sections delimited by numbered stakes or by paint spots in the road. Each grid started at road center, ran $20 \mathrm{~m}$ perpendicular to it, and $40 \mathrm{~m}$ along the road. The first $10 \mathrm{~m}$ away from the road midline consisted of about $4 \mathrm{~m}$ of pavement, and $6 \mathrm{~m}$ of graded surface. The surface is infrequently graded and last year's dead annual plants were present. The next ten $\mathrm{m}$ away from the road contained $0-2 \mathrm{~m}$ of graded surface, then 8 to $10 \mathrm{~m}$ of visibly taller and wider shrubs associated with the berm at the margin of roadside disturbance. In some places the area 10 to 20 $\mathrm{m}$ from the road contained up to $2 \mathrm{~m}$ of vegetation of a height more typical of shrubs away from the road. Thus the first $10 \mathrm{~m}$ away from the road encompassed highly disturbed areas, potentially containing negative road effects, while the second $10 \mathrm{~m}$ away largely contained potential positive road effects. Ten $20 \times 40 \mathrm{~m}$ control plots were placed in a similar vegetative community 300 to $1000 \mathrm{~m}$ from the main DAF entry road. Both roadside and control plots were arranged along 1 ines that went outward away from the DAF.

Plots were searched for lizards which were noosed, measured from snout to vent (SVL) to the nearest $0.5 \mathrm{~mm}$, weighed to the nearest $0.05 \mathrm{~g}$ on a top loading balance, marked, and released as described in Medica and Hunter (1989). Plots were sampled one to three hours after sunrise over a temperature range favorable for 1izard activity. For most of the sampling period, temperatures favored lizards basking on the edge of shrub clumps. Lizard plots were not surveyed on overcast or exceptionally windy days. Sampling started from opposite ends of the lines of plots on successive days so that each plot was sampled early and late during the sampling period. These plots were sampled on five days from 29 March 1993 to 6 April 1993, and resampled for five days from 2 to 6 August. Results are reported separately for spring and summer studies. Four people collected lizards, and each spent some time on each plot.

Data were analyzed in several ways to facilitate comparisons across three areas: the first $10 \mathrm{~m}$ away from the road center (= potential area of negative effect, treatment 1), area from 11 to $20 \mathrm{~m}$ from the road (= potential area of 
positive effect, trt 2), and the control area well removed from the road (= trt 3). In each plot, two estimates of numbers were used: total number of separate individuals caught per plot over 5 days, and mean number of lizards caught per plot per day. The former represents total number of Tizards using the plot, while the latter represents average daily plot use. The mean \pm two standard errors of the mean ( $2 \mathrm{se}$ ) was used to describe variation across plots within each treatment. Average daily plot use was expressed on a per hectare basis. Mean weight, mean snout-vent length, and the proportion of the population that was female, were also computed per plot and compared across treatments. Proportion of the population that was female (a measure of the sex ratio) was arc sine transformed to facilitate parametric comparisons. Lizards were assigned to cohorts (this year's young, last year's young, young born prior to last year) based on relationships between SVL and age estab7ished on individuals of known ages on the NTS (unpub7ished data). A chi square test was used to compare frequency of individuals in each cohort, to determine if age structure differed across treatments. Number of recaptures from spring to summer surveys was compared between roadside and control areas with a chi square test. This test asks whether survival or dispersal off plots differs between these two areas.

To assess overal1 road effects on lizard traits, estimates from treatments 1 and 2 were combined, and compared to those from treatment 3 with an analysis of variance (ANOVA). Next, to tease apart the potentially negative and positive effects of the road, treatments 1,2 , and 3 were contrasted with an ANOVA, and post hoc comparisons made with Tukey tests. Finally, Spearman rank correlations were performed to test for an association between lizard traits and proximity to the DAF buildings.

In an attempt to determine causal factors that could explain differences in lizard distributions, 100 vegetative transects were arranged along the road side, and 100 more in the control area. One transect was randomly assigned a position within each $10 \mathrm{~m}$ along the road edge or the control. Transects ran perpendicular to the road, or the long axis of the control line, and were designed to assess shrub density. Shrub density was examined by recording number of each shrub species present in $101 \mathrm{~m}$ sq plots located at $1,3,5,7$, $9,11,13,15,17,19 \mathrm{~m}$ from road center, or at $1,5,9,13$, and $17 \mathrm{~m}$ north of the small mammal line located along the south edge of the control plots. Number of shrubs per species per transect (= per $5 \mathrm{~m} \mathrm{sq}$ ) were compared across treatments with an ANOVA. 


\section{DAF Diversion Ditch Studies}

To assess effects of the ditch located upslope of the DAF buildings and associated disturbances, 12 plots were placed in undisturbed vegetation approximately $200 \mathrm{~m} \mathrm{NW}$ (up slope) of the main DAF building, and six plots were arranged in the ditch-bottom created to divert water around the DAF building (Figure 1). Each plot was $20 \times 50 \mathrm{~m}$ and 7aid out with wooden stakes on a $10 \mathrm{~m}$ rectangular grid. Half of the 12 control plots were placed in arroyo bottoms, and half on flat areas located between arroyo bottoms. Plot locations were determined by walking in a predetermined direction roughly parallel to the edge of the disturbed area associated with the DAF. A plot was placed on each aspect-type as it was encountered, as long as it was large enough to contain a plot.

Lizards were noosed, measured, marked, and released as discussed by Medica and Hunter (1989). A small fraction of attempted captures were successful with Cnemidophorus tigris (whiptails) and Callisaurus draconoides (zebra-tailed lizards). Missed lizards were added to daily plot totals for this analysis. other survey aspects were similar to those given under roadside studies. Plots were sampled five times from 30 April 1993 to 10 May 1993, and resampled five times from 9 to 13 August, with all plots sampled each day. Statistical analyses were similar to those discussed for roadside studies, with arroyo and flat data pooled and compared with the disturbed ditch site, and then all three treatments compared. In addition, total number of species and total number of individual lizards seen on each plot (pooled across species) were also compared across treatments.

\section{Lizard Transects}

Lizard transects were walked on three consecutive days from 30 May 1993 to 2 June 1993. On each day three investigators walked abreast along the long axis $(1000 \mathrm{~m})$ of a transect and recorded numbers of each species seen per $50 \mathrm{~m}$ interva1. Three transects were walked each day: one $15 \mathrm{~m}$ wide located in undisturbed vegetation along lizard control plots south of the DAF; one $15 \mathrm{~m}$ wide centered on the berm approximately $20 \mathrm{~m} \mathrm{~S}$ of the paved DAF road; and one $10 \mathrm{~m}$ wide line located from the center of the paved DAF access road out into the bladed area along the road edge. These transects were designed to assess habitat wel1 removed from road effects, habitat containing vegetation of natural height and taller vegetation associated with the berm (but close to the road), and highly disturbed habitat in or at the margin of the road. The 
three transects examine habitats similar to those examined with the Tizard plots, but are designed to examine more mobile species that are $i 11$ suited to examination with our plot-sampling techniques. Raw counts (number $/ 50 \mathrm{~m}$ ) were extrapolated to 1 hectare-sized areas to facilitate comparisons across transects of unequal widths, and compared with a two way analysis of variance with days and transect location as factors.

\section{DAF Timed Surveys}

To assess reptile species distributions near the DAF, a series of walking censuses (Campbel1 and Christman 1982) were performed from 29 June to 1 July. The DAF area was divided into five areas: disturbed area immediately surrounding the DAF buildings (including the diversion ditch), area south of the DAF out to $1 \mathrm{~km}$, area north of the DAF to the water tank, area from the water tank to the foothills, and $0.2 \mathrm{~km}$ into the foothills (Figure 1). Within each area an investigator walked slowly, rolled rocks, fallen Yucca or other debris, and searched for 30 minutes, recording number of each repti7e species encountered per search. Next, investigators moved to one of the other four areas and did another 30 minute search. Over three days, each investigator searched two 30 minute periods in each of the five areas. Number of lizards per species seen per 30 minute period, total number of 1izard species seen per 30 minutes, and total number of Tizard individuals seen per 30 minute period were recorded and compared with an ANOVA with location and investigator as main effects. Effect of time of search on lizard counts was examined with a one way ANOVA. These analyses test for differences in relative abundances across locations, and ask how large temporal and investigator effects were on estimates of Tizard numbers.

\section{Reptile Species}

A reptile species list was generated from our sampling efforts at the DAF. Most of our time was spent in some sort of quantitative sampling, however, some effort was spent simply searching for resident reptiles. A11 observations of living or dead reptiles were noted. 


\section{BIRDS}

\section{Sewage Pond Effects}

Bird use at DAF sewage ponds was recorded from March through November and compared to an undisturbed habitat nearby to gain understanding of how addition of a settling pond may influence a desert bird community. The pond provided unlimited water to birds, which otherwise would be limited. Bird populations near water sources in arid regions are known to benefit from increased water availability (Szaro and JakTe 1985).

Pond use was estimated by recording bird visits per hour. Most birds were flushed from the pond area before a count began. A visit occurred when an individual entered, spent some time and left the area of the pond or its sloping banks. Birds were difficult to count when numerous (some were missed), in many cases leading to underestimates of total birds. Birds were counted in 12 consecutive 5 minute intervals at the sewage pond and then repeated at a natural location (Plot 1, Figure 1 ).

Different counting techniques were used because of marked differences in visibility of birds in the two areas. At Plot 1 , counts were made from the center (first 3 visits) and thereafter the plot was searched by flushing birds from cover out to the $150 \mathrm{~m}$ radius. The natural area searched $(8 \mathrm{ha})$ was much larger (>50 times) than the sewage pond area $(0.15 \mathrm{ha})$. This was done because many birds staged in areas near the sewage pond before arriving, making the actual area occupied much larger. Counts were recorded between 0800 and 1300 h. The sewage pond was censused before the undisturbed habitat on most dates. Order was reversed on one date and done at the same time on several occasions.

Because this was a pilot study, several methods-modifications were evaluated. Initially, counts at the sewage pond $(N=6)$ were made from outside the vehicle from a fixed location. On 5 May 1993, dove visits were estimated from outside and then inside a parked vehicle to determine observer effects. Thereafter, counts were made from inside the vehicle. Air temperature (in shade at waist height) was recorded for seven dates after sampling was complete and compared ( $t$-test) between pond and natural areas.

Total visits per hour were compared across species and date using analysis of variance (ANOVA) and post hoc Tukey comparisons. Five minute counts were used to test for differences in species use between sewage pond and natural plots 
for most dates using $t$ tests, or Kruskal-Wa11 is tests when parametric assumptions could not be met.

Ravens were counted during each pond visit and expressed as number/hour of observation. An ANOVA was used to test for seasonal differences in raven counts at the sewage pond.

\section{Natural Habitat Sampling}

Breeding bird density was estimated for selected species at the DAF using a variable circular plot technique (Reynolds et al. 1980). Birds were identified by sight and vocalization (song and calls) from a central location. Eight replicate plots were chosen in undisturbed habitat, five located away and three near the sewage ponds (Figure 1). The black-throated sparrow (Amphispiza bilineata) was chosen for initial monitoring efforts because it was locally abundant. Plots in natural habitat were compared with ANOVA, to examine possible effects of the pond.

Observer counts were made between the hours of 0700 and 1000 during peak activity patterns (singing) of passerine species. Two minutes after arrival at the plot center (allowing birds to adjust to the observer), all species seen during a nine minute period were recorded. Birds were located and identified with binoculars $(7 x)$, and radial distance to the spot where they were first observed was visually estimated. Numbered stakes were located at radii of $25,30,40,50,60,75,100$ and $150 \mathrm{~m}$ from the center to aid the observer in distance estimation. The procedure was repeated for each plot on 6 dates.

Before density could be estimated, counts were used to compute the radius of detectability (RD) for each species. This was the distance where numbers of birds observed per concentric band reached a peak, defined by dec 7 ines of 50 percent or more in more distant bands, because birds were not detected as we11. All bird locations were mapped in concentric band areas of the plot as defined above, and RD was estimated.

Species density was calculated from number of birds seen out to RD, divided by the plot area also defined by RD. Mean density was estimated by averaging counts by plot and date over the breeding season of a species (Apri1-May). Bird densities in desert ecosystems are generally low. Therefore, the null 
- hypothesis that bird density was not significantly greater than 0 was tested (t-test).

Numbers of nests, eggs, hatchlings, and fledglings were recorded during field efforts when time permitted. Finally, a bird species list was summarized for 1993. All descriptive statistics shown include \pm 2 se.

\section{SMALL MAMMALS}

Animal ecology studies on the NTS were initiated in 1959 when Brigham Young University cataloged fauna of the NTS (A7Tred and Beck 1963; Jorgensen and Hayward 1965). The University of California Los Angeles sponsored several projects in Rock Valley on the southern edge of the NTS to determine animal abundance, home range, effects of chronic radiation, and Tife spans in a population of desert rodents (French 1964; French et a1. 1966, 1967; French et a1. 1974; French et a1. 1968; Maza et a1. 1973). Additional smal1 mammal studies were done in Rock Valley as part of the International Biological Program during the 1970s (Chew 1975; Dingman 1975; Turner 1973, 1975; Turner and McBrayer 1974). During the late 1970s and early 1980s, the Nevada Applied Ecology Group studied rodents at several contaminated sites (Moor and Bradley 1974, 1987; Bradley and Moor 1975, 1976, 1978; Moor et a7. 1976; Bradley et a1. 1977a, b; Moor et a1. 1977; 0'Farre17 and Sau7s 1987). Currently, BECAMP monitors the flora and fauna of the NTS (Hunter and Medica 1989; Hunter 1992).

Fifty-seven mammal species occur on or near the NTS (Appendix A), most7y rodents (Jorgensen and Hayward 1965; 0'Farre11 and Emery 1976; Medica 1990). Three bat species, Lasionycteris noctivagans (silver-haired bat), Eptesicus fuscus (big brown bat), and Tadarida brasiliensis (Mexican free-tail bat) were overlooked in the earlier species accounts, although three specimens collected in 1963, 1964, and 1978 exist (Saethre 1994). Five other species, Euderma maculatum (spotted bat), Lasiurus cinereus (hoary bat), Myotis evotis (1ongeared myotis), Myotis thysanoides (fringed myotis), and Myotis volans (7onglegged myotis), were first recorded on the NTS in 1992 and 1993 (EG\&G/Energy Measurements 1992, 1993). Overlooking so many bat species is not surprising as intensive studies had not been undertaken until recentiy. Another eight bats are possible residents of the NTS based on geographic distributions (Hall 1981). Two ungulates, elk (wapiti) and bighorn sheep, reside outside NTS boundaries and are rarely observed on site. Burros are found only on the southwestern edge of the NTS. 
of 23 rodents inhabiting the NTS, the most ubiquitous are heteromyids (kangaroo rats and pocket mice). Abundance and species diversity vary among the habitats present on the NTS. In general, Dipodomys merriami (Merriam's kangaroo rat) and Perognathus longimembris (1ittle pocket mouse) are most common in the southern half of the NTS (Mojave desert) while $D$. microps and $P$. parvus (Great Basin kangaroo rat and pocket mouse) are more prevalent in the northern extremes (Great Basin Desert). However, in the last two years, $P$. longimembris has persisted at low densities while Chaetodipus formosus (longtailed pocket mouse) has increased. A murid rodent, the deer mouse (Peromyscus maniculatus) also increased in abundance in the last few years. The increase of this rodent has been linked to an outbreak of Adult Respiratory Distress Syndrome off the NTS. This i17ness is caused by a hantavirus carried by the deer mouse and passed on to humans via contact with rodent excreta.

The objective of the small mammals portion of the pre-operational monitoring at the DAF was to obtain baseline data on species diversity and relative abundance. Simple site characterization of small mammal populations was deemed a priority to facilitate future monitoring needs. Effect of the roadside was also considered tantamount to operational effects of the DAF itself, and was also given consideration in pre-operational surveys.

\section{Rodent Presence and Abundance}

Three traplines were constructed around the DAF (Figure 1). One line (FRF008) ran parallel to the entire length $(1180 \mathrm{~m})$ of the paved road from the DAF to Mercury Highway. 119 trap stations were located at 10-m intervals. FRF008 was $20 \mathrm{~m}$ from the road centerline and approximately $7 \mathrm{~m}$ from the graded area of the road. A 7 ine of equal length ran from the east side of the sewage ponds to the southeast (FRF009). This line went through generally undisturbed habitat, but small localized disturbances such as gravel pits and old roads were present. A third line of $1180 \mathrm{~m}$ (FRF011) was approximately 300 meters north of the flood dike. This line was parallel to the dike with the entire length in undisturbed habitat of arroyos and flats. Line designations continue from other study areas in Frenchman Flat (FRF) and will sometimes be abbreviated as 8,9 or 11 .

Areas close to the DAF were not trapped as they were severely disturbed: most of the disturbance around the DAF involved removal of a11 vegetation and 
compaction of soil or the addition of several centimeters of gravel. None of these are conducive to sma11 mamma1 activities such as foraging and burrowing.

Traps were of two types: standard sheet metal (Sherman live trap, $8 \times 9 \times 30$ $\mathrm{cm}$ ) or galvanized-after-welding wire mesh (A Thru $Z$ Consulting and Distributing, North Hollywood, CA, Trip-itt live mesh trap, $7.5 \times 8 \times 26 \mathrm{~cm}$, $0.5 \times 1.0 \mathrm{~cm}$ mesh). Wire mesh traps were shown to be more effective in trapping Dipodomys stephensi and D. merriami (0'Farre11 et al. 1992). 0'Farrel1 et a1. also found that for all heteromyid rodents and one cricetid the trend was to enter mesh more readily than Sherman traps.

Traps were handled at all times with gloves to minimize human scent on traps and one of each trap was $\mathrm{placed}$ at each stake. Half-cylinder sheet metal trap covers were used to protect animals from heat stress. Bait (rolled oats and birdseed) was placed in traps just before sunset. Traps were checked at sunrise the following morning and a 11 traps were closed for the day.

Kangaroo rats (Dipodomys spp) were given individually numbered ear tags while all other rodents were marked with a unique toe clip. Each field worker was assigned a different toe to $c l i p$ when using ear tags to facilitate identifications of animals with Tost ear tags. Species, animal number, sex, age, reproductive status, location, trap type, weight, and any notes were recorded on data sheets and the animals were released where captured.

For the initial trapping session, all three lines were trapped simultaneously for three nights with both traps activated each night. This gave animals the opportunity to choose which trap was preferred and test the hypothesis that trap type had no effect on trap success. Traps were checked on 8-10 June 1993. Lines were divided into eleven 10-stake units for analyses with the odd number traps on the ends trapped but not included in the analysis. This was done to limit the edge effect in the sections tested. Since trap success generally increases from day one to day three (personal observation), the 3day average for each 10-stake section was used in statistical calculations.

Lines 8 and 9 were trapped again on the nights of 28-30 June. To test if trap success would increase or decrease after a change in trap type, only one trap was set per stake. On each 1 ine, five 10-stake sections were set with Sherman traps and the other five with mesh. Traps were set in blocks and not alternated so that animals would not have the opportunity to choose a different trap type $10 \mathrm{~m}$ away. The appointed trap was activated two nights 
with the other trap substituted on the third night. Although trapped, a 10stake section in the center of each line and traps on the ends were not included in the analyses. Effectiveness of mesh versus Sherman traps was assessed by trap success (percent of traps with captures/traps available).

Trap success by site and trap-type and site and date were analyzed using twofactor analysis of variance with an interaction term (ANOVA, RS/1, BBN Software). Mean weights of adult rodents were compared by two-way ANOVA across site and sex to determine overal1 effect of site on mean biomass, which may vary by sex. Mean weights of adult females (a priori assay of reproduction) of the most abundant species were compared across sites and dates with a twoway ANOVA. Single factor ANOVA was used with a multiple comparison test (Newman-Keuls multiple range test) to evaluate significant results. Contingency tables with the chi-square $\left(X^{2}\right)$ statistic were used to test for differences in weight distributions of the most common species. Gart's test for effect of treatment and order $\left(X_{c}^{2}\right.$, Zar 1984:159-160) was used to determine if trap type and order of presentation (1ate June only) had any effect on trap success. Species diversities $\left(H^{\prime}\right)$ on the three 1 ines were estimated using the Shannon Index and associated t-test (Zar 1984:146-148).

DAF maintenance personnel used kill traps to catch rodents inside the structure. Because permanent doors were not in place, numerous rodents were caught inside and passed on to BECAMP workers for identification.

\section{Presence of 0ther Species}

Mist nets (Avinet, Inc, Los Angeles, CA) were set for one night along the edge of one of two DAF sewage Tagoons. One pond was empty and therefore not included. Nets were black and $3^{\prime} \times 42^{\prime}, 2$ shelf or $3^{\prime} \times 21^{\prime}, 3$ shelf with no more than 1-1/2" mesh. All nets were low visibility, nylon strand either monofilament, 40 denier or two-ply, 30 denier. Nets were hung just above the water surface at the shallow end (north and west) on poles of various heights (Figure 3). Nets were in place before sunset (approximately $2000 \mathrm{hrs}$ ) on 19 July 1993 and struck at $0230 \mathrm{hrs}$ next morning due to high winds.

Mammal observations, including tracks and scats were recorded. Jackrabbit observations were recorded from natural areas, expressed as number/hr and examined with ANOVA for seasonal change. 


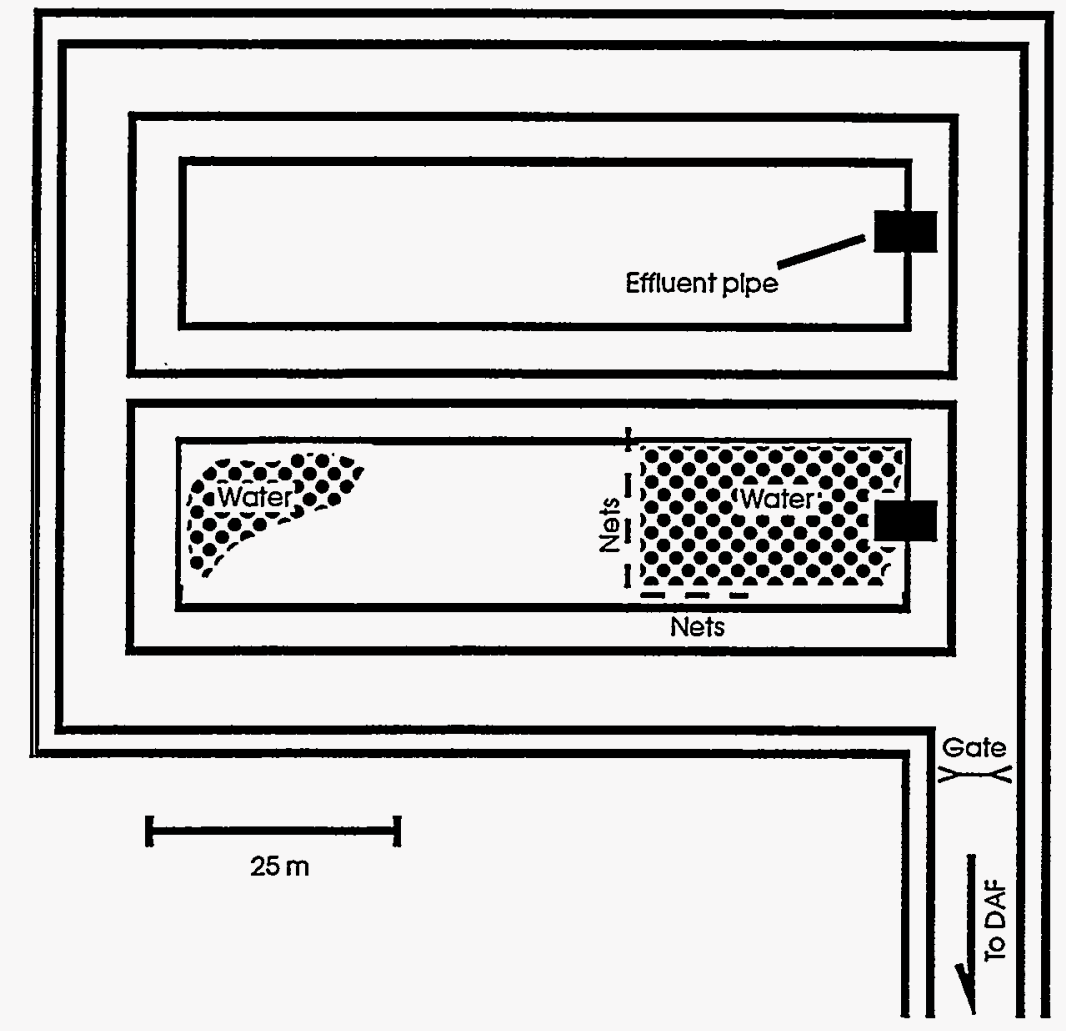

Figure 3 - Location of mist nets at the DAF sewage ponds on 19 JuTy 1993.

\section{RESULTS}

\section{EPHEMERALS}

Ephemerals were sampled in four locations. There were 89 species (Appendix B) identified in all study sites. Twenty-six were seen at all locations and can be considered common. Only one introduced species, Bromus rubens, was found at all locations. Fifteen species were present in three of the four locations (including 6 introduced), twenty were present in two (two introduced), and the remaining 28 were seen in only one (none introduced). A7though species seen in only one location could be considered rare on the NTS, none have been suggested for listing as a threatened or endangered species, and there were none on the list of sensitive plant species for Nevada (Moorefield and Knight, 1991). Four species were grasses, Bromus rubens and B. tectorum, Schismus arabicus, and Vulpia octoflora. Vulpia was the only native annual grass seen at the DAF. 
Tabie 3. Summary statistics on two $1000 \mathrm{~m}^{2}$ transects.

DAF1 was about $50 \mathrm{~m}$ north of the ditch above the flood protection dike, DAF2 was on a scraped, graveled area south of the DAF. * = the two plots differ in this parameter at $P<0.05 ; * * P<0.01$, d.f. $=38$.

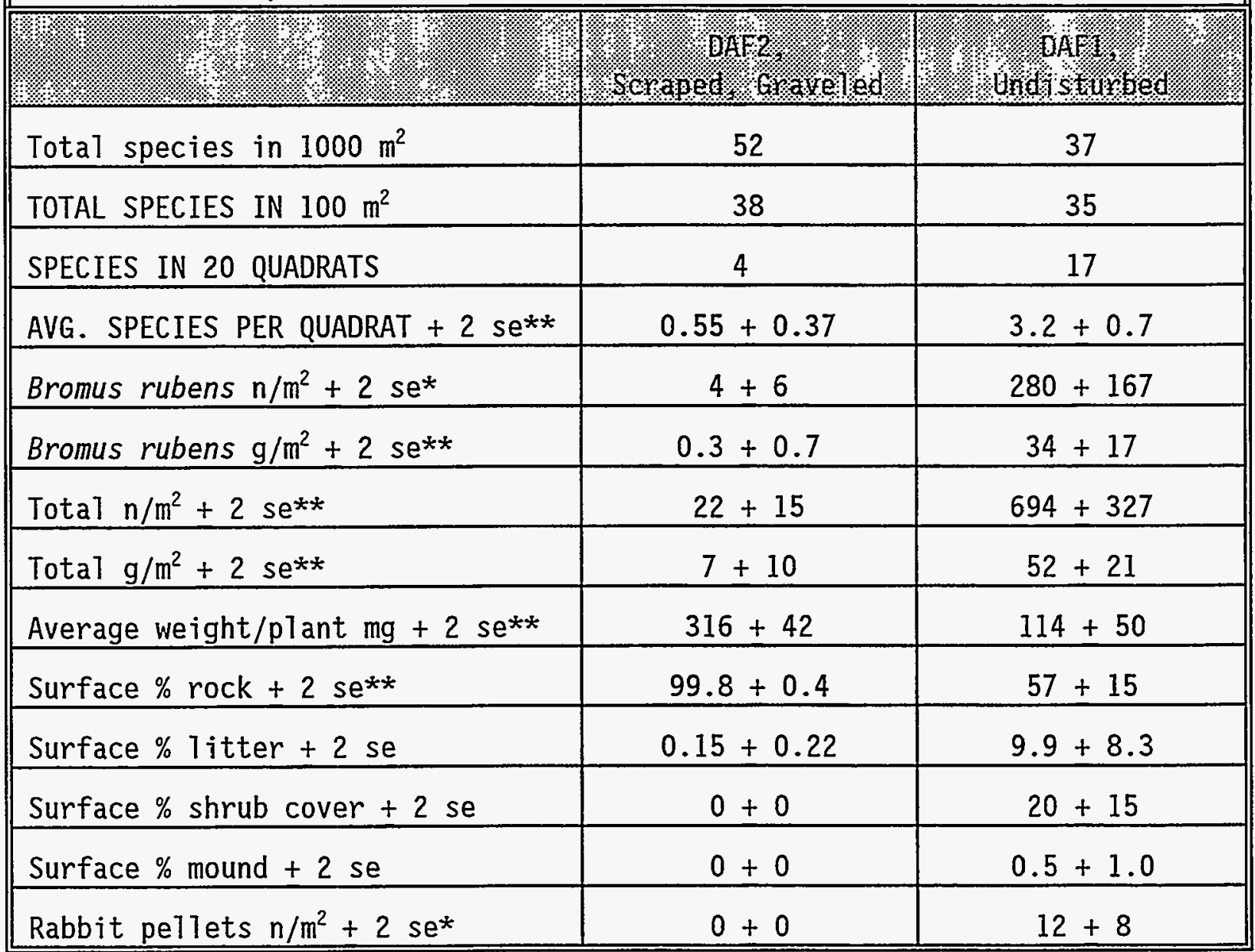

On p7ot DAF2, ephemeral densities were low by historical standards (Hunter $1991,1994 a, b$, Table 3), but the number of species present in 100 and $1000 \mathrm{~m}^{2}$ was unusually large. The species with highest densities were Salsola australis (Russian thistle - introduced) and Phacelia fremontii, both with $8 \pm 7$ plants per square meter ( \pm 2 se, Appendix C). Eriogonum deflexum, which was extremely common and dominant on most disturbed areas around the DAF in 1993, was present at $<2 \mathrm{plants}$ per square meter at this site. Salsola australis is common on disturbed areas on the NTS, but 8 plants per square meter is a low density. 
The environments of these two sites were very different due to the scraping and gravel spread on DAF2. There was better growth (1 arger average size) on DAF2 $(t=4.26,38$ d.f., $P<0.001)$, but far fewer plants $(t=2.83,38$ d.f., $P<0.01)$, and far less biomass produced ( $t=2.67,38$ d.f., $P=0.0115$, Table 3.). The large number of species present, and the sparse plant populations, suggest the DAF2 area was recently scraped and had not yet had several generations of plant growth. Most such areas would, after several years, be dominated by Salsola australis.

The standard BECAMP technique was also used to characterize ephemerals near the paved roadside (Table 4). Eriogonum deflexum dominated the scraped area and Bromus rubens the undisturbed areas. There were more species in the undisturbed areas, more litter on the surface, and greater shrub cover. Rabbit pellets were only seen on and adjacent to the scraped area, but variability was too great to show a statistical difference (Table 4, Appendix C).

Table 4. Summary statistics on three $100 \mathrm{~m}^{2}$ transects at DAF3. One was on the scraped road shoulder, one immediately adjacent to the scraped area, and the third fifty meters from the pavement edge. * = significant at $P=$

\begin{tabular}{||l|c|c|c||}
\hline TOTAL SPECIES IN $100 \mathrm{~m}^{2}$ & 9 & 21 & 26 \\
\hline SPECIES IN 10 QUADRATS & 2 & 9 & 12 \\
\hline AVG. SPECIES PER QUADRAT* & $1.4 \pm 0.3$ & $2.7 \pm 0.7$ & $2.6 \pm 1.0$ \\
\hline Bromus rubens $\mathrm{n} / \mathrm{m}^{2} \pm 2 \mathrm{se}$ & $16 \pm 13$ & $336 \pm 496$ & $468 \pm 373$ \\
\hline Bromus rubens $\mathrm{g} / \mathrm{m}^{2} \pm 2 \mathrm{se}$ & $0.3 \pm 0.3$ & $9.7 \pm 10.2$ & $32.1 \pm 24.8$ \\
\hline Eriogonum deflexum $\mathrm{n} / \mathrm{m}^{2} \pm 2 \mathrm{se}$ & $1952 \pm 728$ & $1260 \pm 372$ & $8 \pm 16$ \\
\hline Eriogonum deflexum $\mathrm{g} / \mathrm{m}^{2} \pm 2 \mathrm{se}$ & $8.9 \pm 3.0$ & $14.2 \pm 6.9$ & $0.15 \pm 0.3$ \\
\hline Total ephemerals $/ \mathrm{m}^{2} \pm 2 \mathrm{se}$ & $1968 \pm 732$ & $1652 \pm 768$ & $560 \pm 395$ \\
\hline Total biomass, $\mathrm{g} / \mathrm{m}^{2} \pm 2 \mathrm{se}$ & $9 \pm 3$ & $25 \pm 11$ & $40 \pm 26$ \\
\hline Average weight $/ \mathrm{plant} \mathrm{mg} \pm 2 \mathrm{se}$ & $10 \pm 6$ & $24 \pm 12$ & $89 \pm 67$ \\
\hline Surface $\%$ rock $+2 \mathrm{se}$ & $62+6$ & $46+13$ & $54+16$ \\
\hline \hline
\end{tabular}




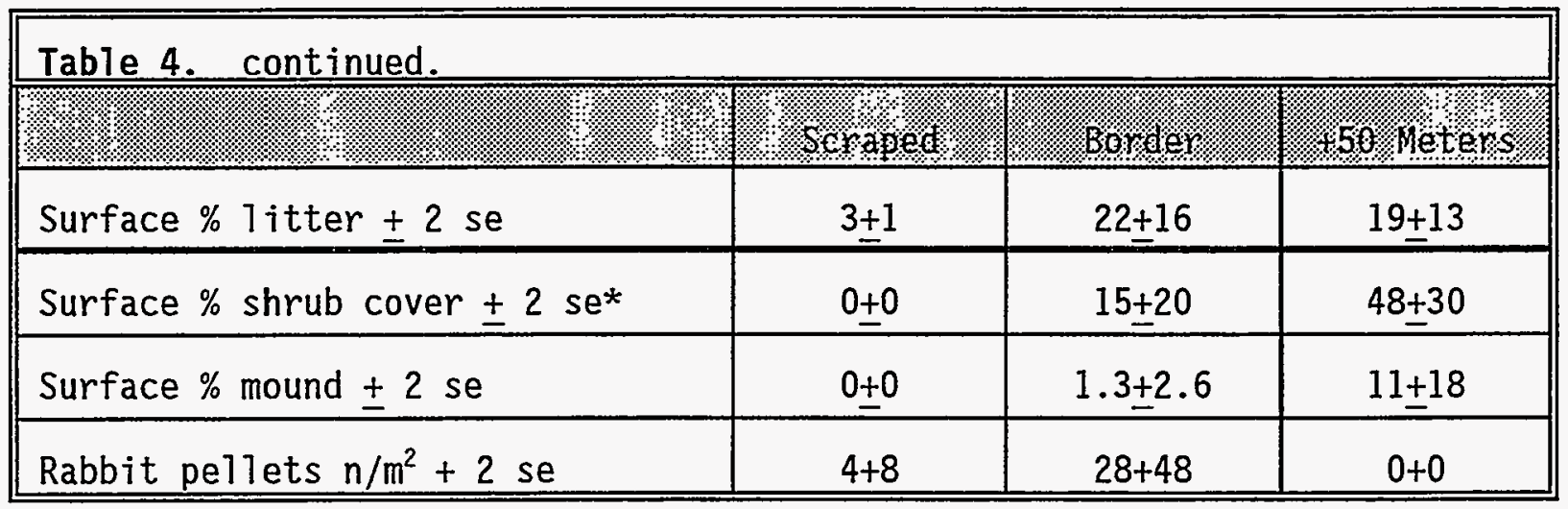

The most obvious difference at this location along the paved road was the dense concentration of Eriogonum deflexum on the scraped edge. Across the three locations the difference in Eriogonum deflexum densities was highly significant $\left(F_{2.27}=17.41, P=0.000014\right)$. Dense concentrations were present in the bordering vegetated area, but not 50 meters from the road (Table 4). The control area differed from both the road shoulder and bordering area (Tukey test). When sampled, these plants were small and not reproductive (the species blooms late spring to early fall, depending on conditions). They therefore represented seed concentrations existing in the soil, rather than 1993 seed production estimates. Besides the increased density of Eriogonum deflexum, fewer species were found in the scraped area, average plant size was reduced, and total biomass was reduced (Table 4 ).

Estimating the $\log _{10}$ densities of all species in $1 \mathrm{~m}^{2}$ quadrats within $50 \mathrm{~m}$ of the paved road edge produced a species list rankable by average log-density (Table 5). In the 200 one-square-meter quadrats examined, Eriogonum deflexum was one of the most frequently encountered (occurring on al1 ten 1 ines), and had the highest average $\log$ density $\left(\log _{10}=1.71\right.$, Table 5$)$. The introduced grass Bromus rubens was next most dense. Bromus rubens is the dominant ephemeral on most of the NTS Mojave Desert areas. 


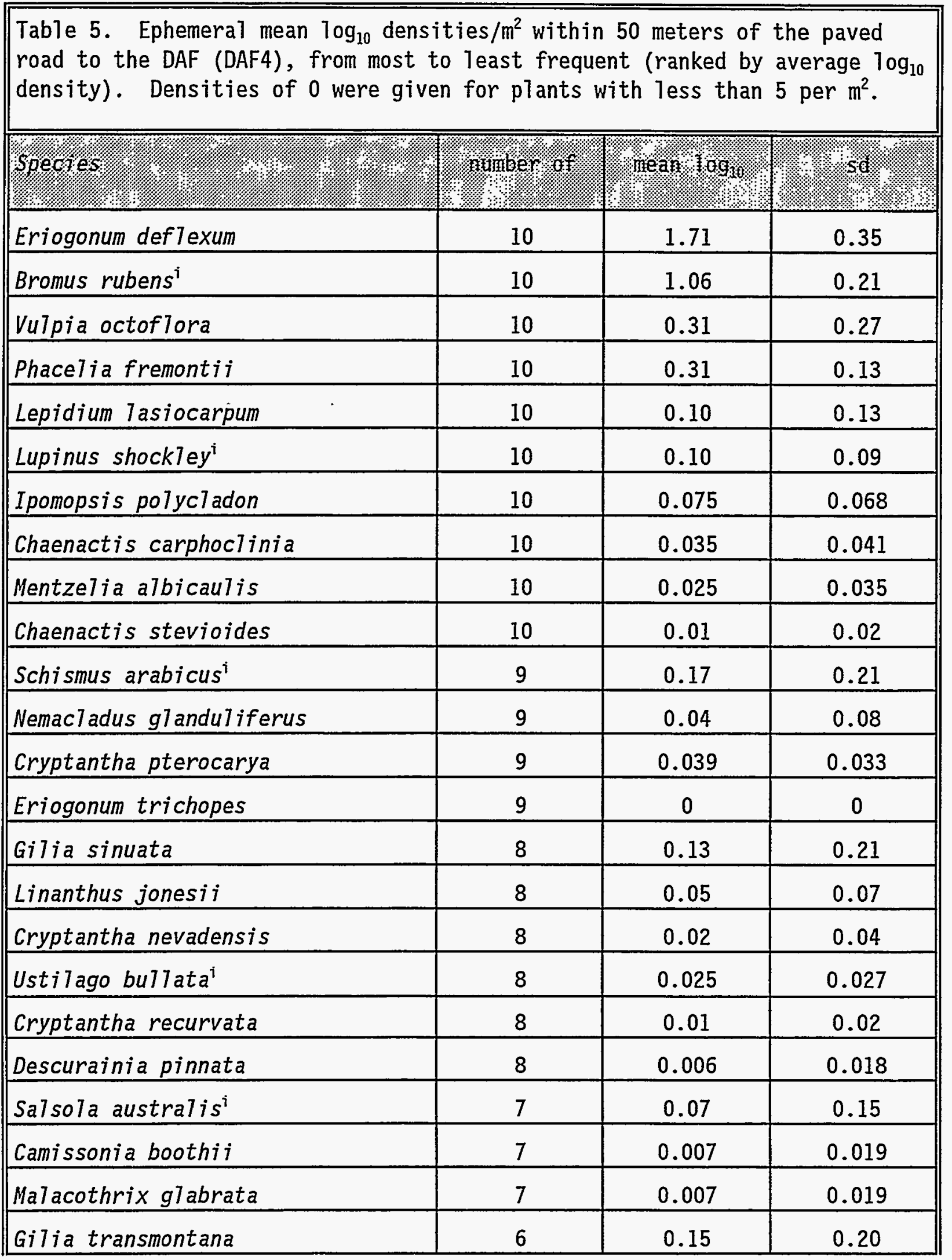




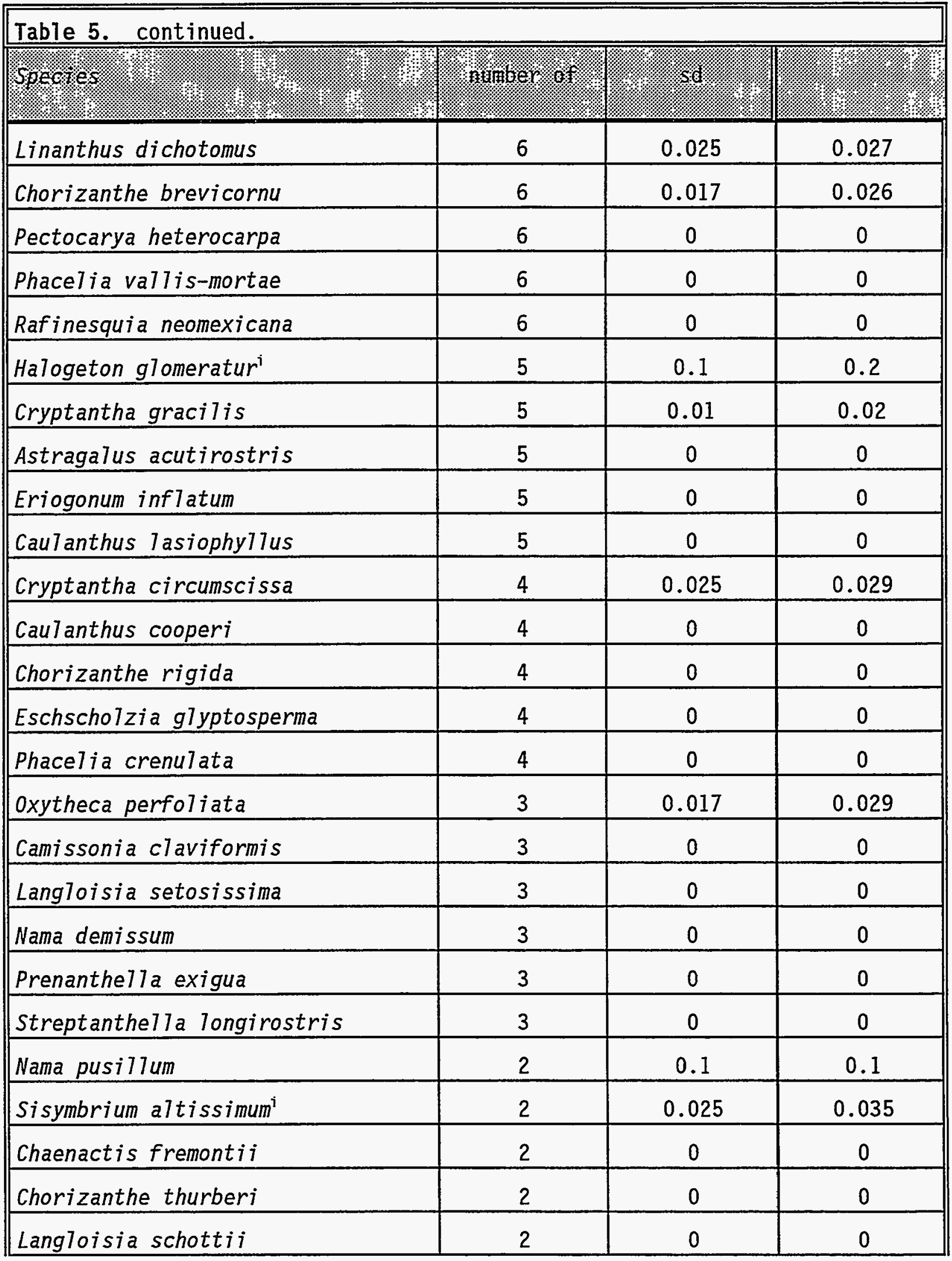




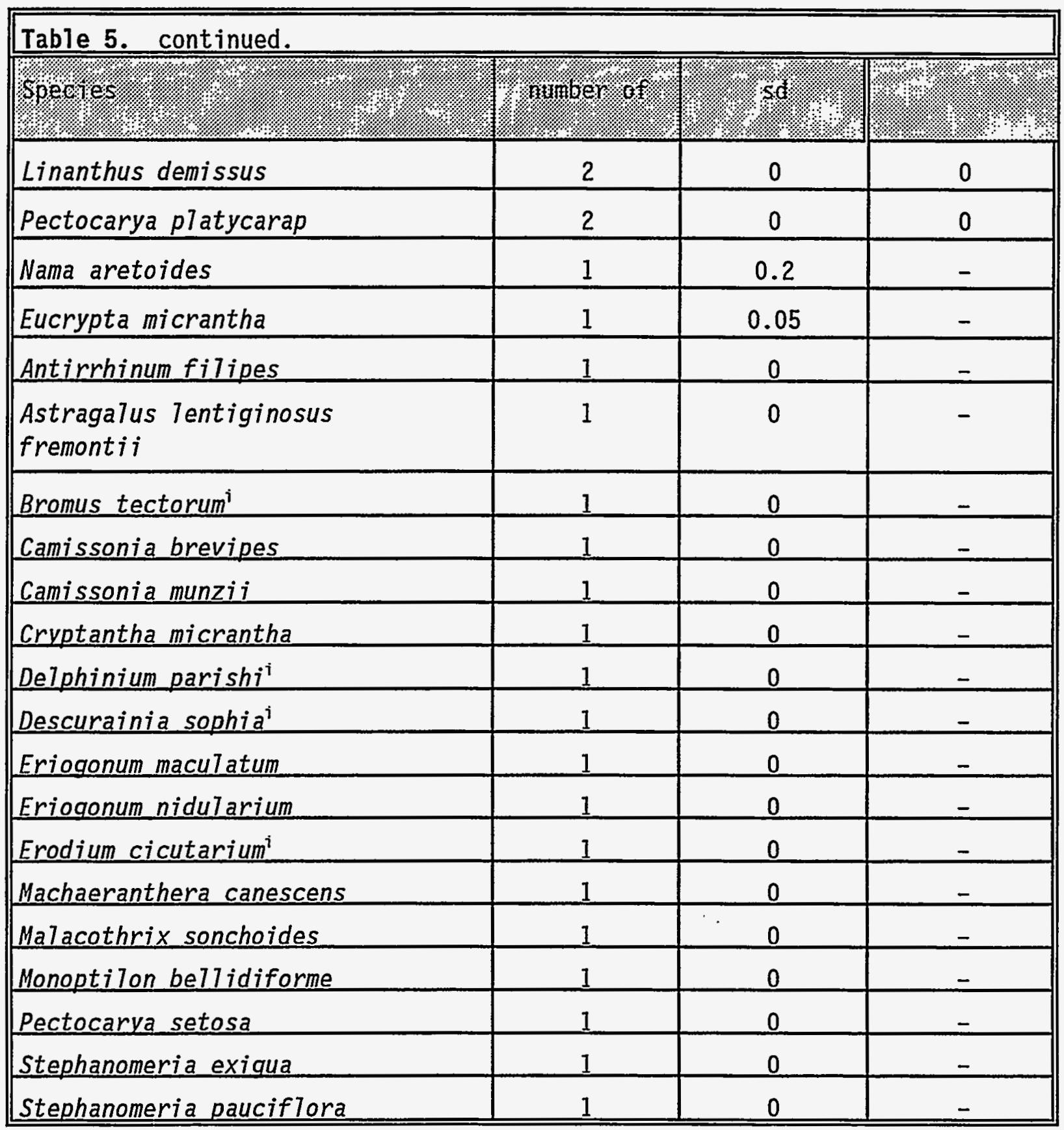

The $\log _{10}$ sampling technique was intended to show the relationship of the more common species to the road disturbance. Figures 4 to 8 show the changes in mean $\log _{10}$ densities of selected species with distance from the pavement edge. Eriogonum deflexum was present in high numbers (hundreds to thousands per square meter) along both edges of this road (Figure 4). Numbers appeared to drop off to a near-constant low level between 25 and 50 meters from the road, around 2 to $3 \mathrm{plants}$ per square meter. It was only present at about $0.25 / \mathrm{m}^{2}$ 
on the dirt road to the water tank, suggesting it behaves differently in the two areas. It is possible, too, that the 2-3 plants per square meter near 50 $m$ from the paved road may represent seed pressure from the roadside plants.

The most abundant ephemeral species on the NTS is Bromus rubens, an introduced species which invaded higher elevations of the Mojave Desert early this century. It was present in unusually low densities $\left(3-4 / \mathrm{m}^{2}\right)$ on the scraped roadside shoulder, but present at 10 times those densities outside the roadside scraped area (Figure 4). Two other grasses were of interest: one was a small native grass, Vulpia octoflora, which was very abundant before Bromus rubens became dominant (Turner and McBrayer 1974), and the other was a very similar introduced grass, Schismus arabicus (Figure 6). Vulpia was absent from the scraped shoulder, concentrated slightly at the boundary, and present

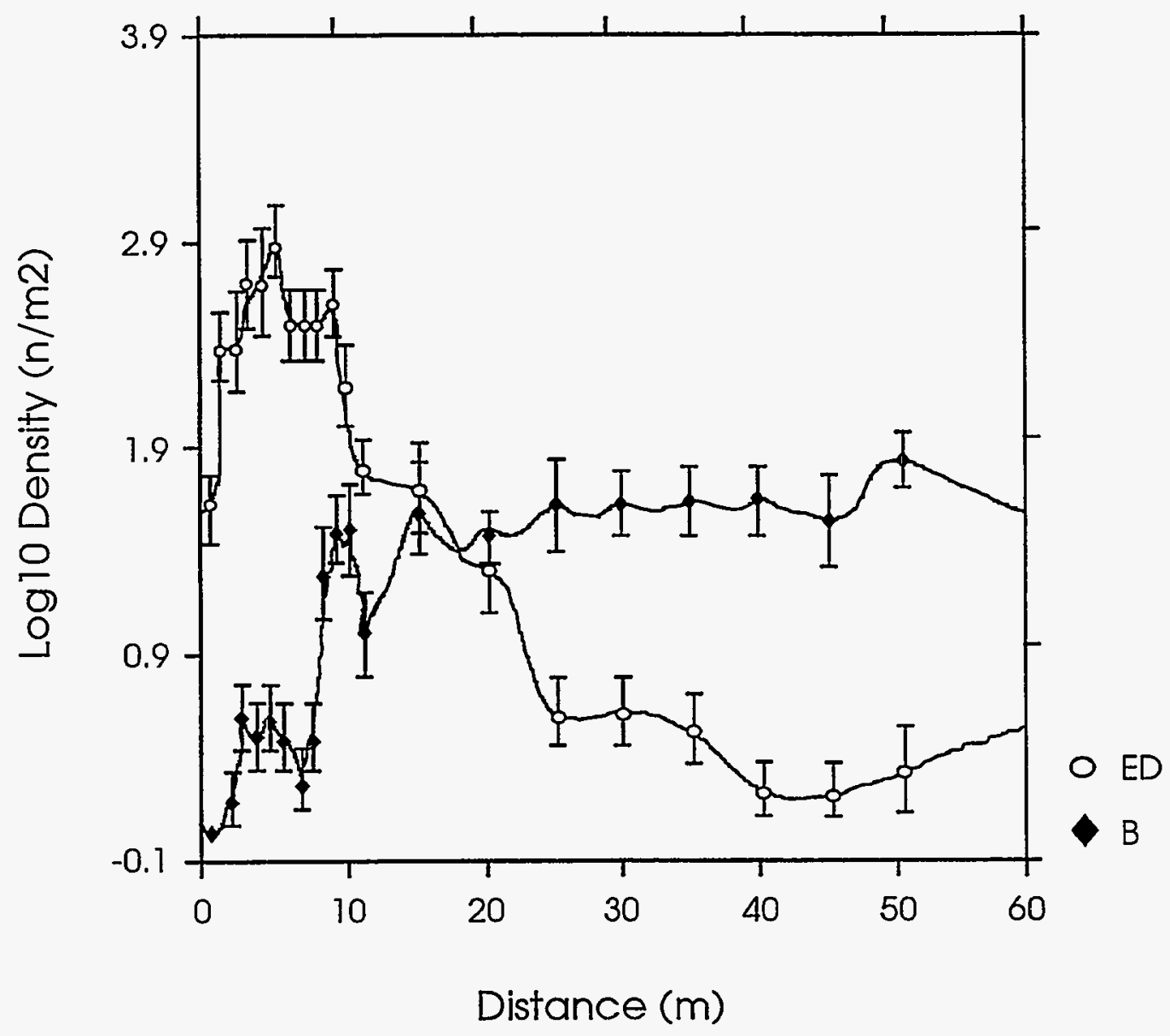

Figure $4-\log _{10}$ densities $\left(\mathrm{n} / \mathrm{m}^{2} \pm \mathrm{se}\right)$ of the two dominant ephemeral species (Eriogonum deflexum and Bromus rubens) within $50 \mathrm{~m}$ of the paved road to the DAF. 
at several plants per square meter in the undisturbed areas (Figure 5). Schismus was present on the shoulders of the paved road and in very low density out to 20 meters, then absent from undisturbed vegetation (Figure 6).

Lepidium 7asiocarpum, a common native ephemeral, appeared to be concentrated along the boundary between the scraped and undisturbed vegetation at the edge of the road (Figure 7). Another common native in the DAF area, Phacelia fremontii, declined precipitously in density at the boundary, and appeared to increase in density with increasing distance from the scraped area.

More species were found per square meter in undisturbed vegetation than on the scraped roadside (ANOVA, $F_{1.18}=33, P=0.00002$ ). The average number of species on the scraped road shoulder was $5.4 \pm 1.4$ per square meter while on adjacent undisturbed areas there were $10.4 \pm \overline{0} .8$ species $(\bar{x} \pm 2$ se, $n=11$ and 9 respectively, data based on mean values).

The sampling technique employing nested quadrats expanded in multiples of two was used at a site along the center of the dirt road leading to the DAF water tank, and at an undisturbed site approximately 50 meters east of that road. Species observed and densities estimated were similar to those seen elsewhere (Appendix B, C, Table 5). However, densities of the most common species (PTots DAF5, DAF6; Tab7e 6) depended strongly on the starting location, and densities of some patchy species were clearly either under- or over-estimated depending on the quadrat size in which they happened to fal1. No replicates were produced by this technique, so estimates of standard errors were not possible. This method was as time consuming as those that did give statistical estimates, and was therefore abandoned. It would have been useful if it had allowed sampling multiple sites quickly. Biomass estimates, derived from one weight and one density, were similarly suspect (Table 7), and could not be tested statistically. In this location it is obvious that ephemeral densities and biomass were much greater in the undisturbed area than on the road. However, the numbers of species in the two locations were nearly identical (49 and 50), and species compositions were generally similar. 


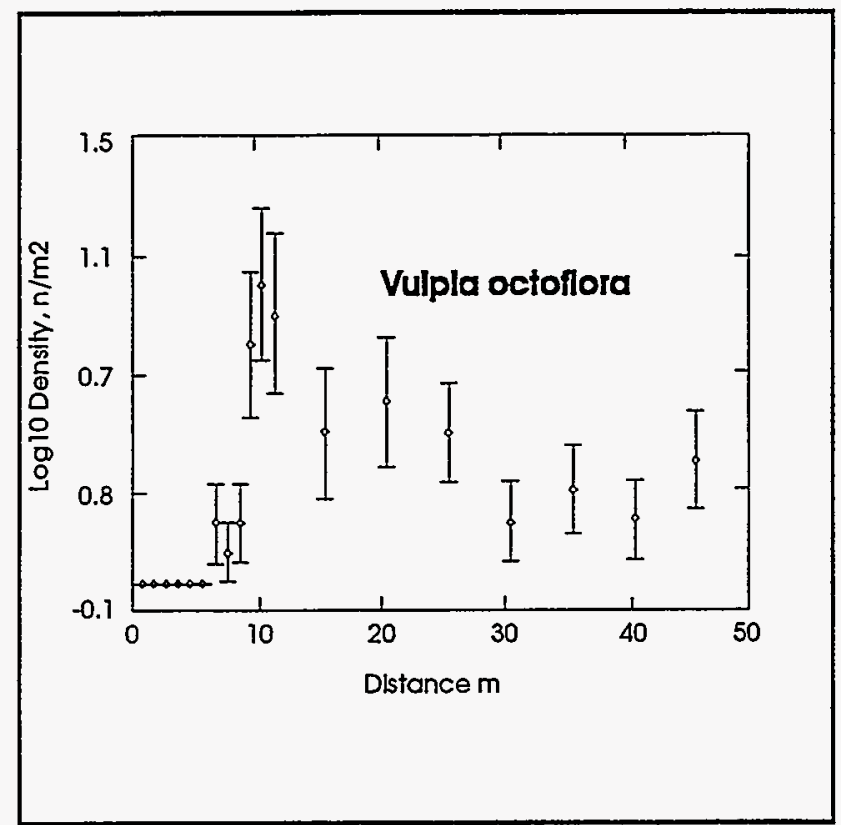

Figure 5 - VuTpia octoflora $\log _{10}$ densities as a function of distance from the paved road.

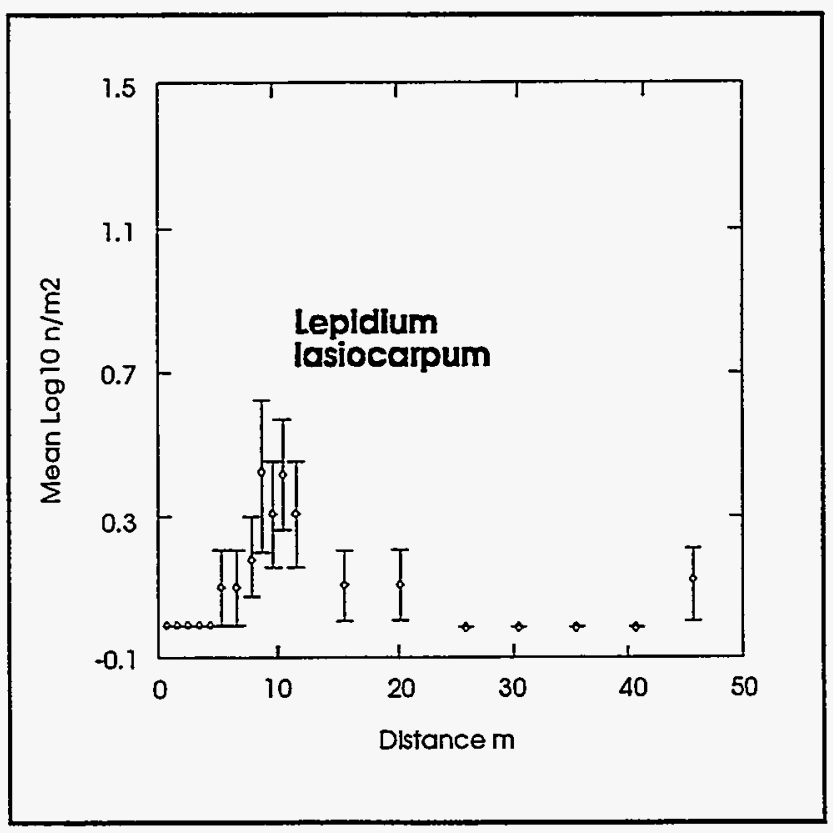

Figure 7 - Lepidium 7 asiocarpum $\log _{10}$ density vs distance from the paved road.

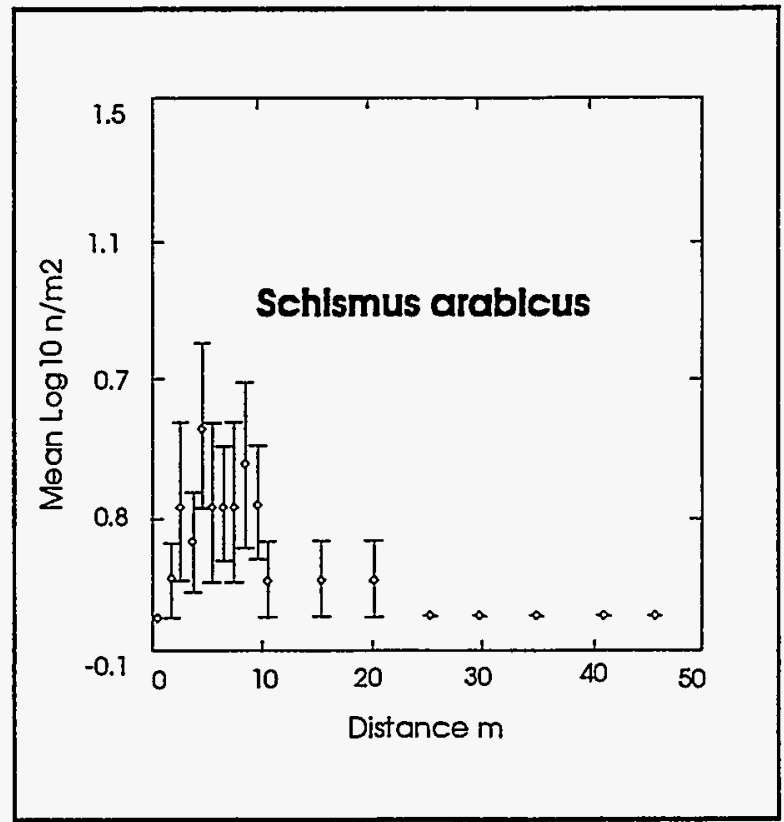

Figure 6 - Schismus arabicus $\log _{10}$ density in relation to the paved road.

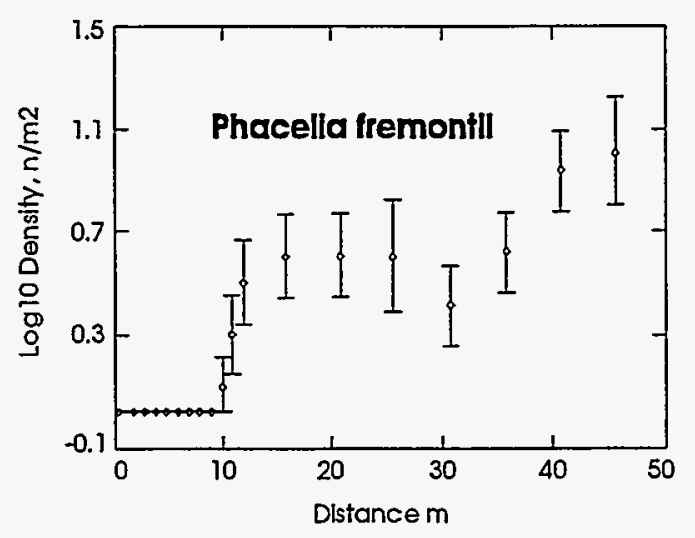

Figure 8 - Phacelia fremontii $\log _{10}$ densities vs distance from the paved road. 


\begin{tabular}{|c|c|c|}
\hline \multicolumn{3}{|c|}{$\begin{array}{l}\text { Table } 6 \text {. Densities }\left(\mathrm{n} / \mathrm{m}^{2}\right) \text { of ephemeral plant species on the dirt road to } \\
\text { the DAF water tank (DAF5) and an adjacent undisturbed area (DAF6). } \\
\text { Estimates are based on densities in twofold expanding quadrats. i indicates } \\
\text { introduced species. Ustilago is a smut fungus infecting Bromus rubens. }\end{array}$} \\
\hline Spectess & 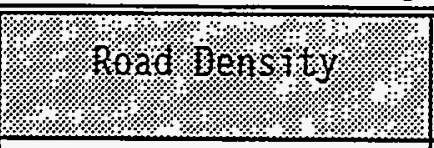 & 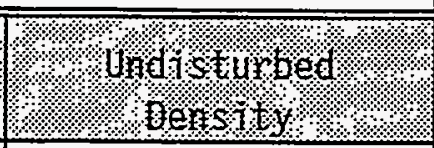 \\
\hline Bromus rubens $s^{i}$ & 8 & 1722 \\
\hline Nemacladus glanduliferus & 4 & 331 \\
\hline Phacelia fremontii & 4 & 179 \\
\hline Usti7ago bullata & 0.12 & 179 \\
\hline Linanthus dichotomus & 0 & 37 \\
\hline Gilia sinuata & 0 & 28 \\
\hline Cryptantha circumscissa & 0.03 & 20 \\
\hline Gilia transmontana & 1.25 & 12 \\
\hline Erodium cicutarium & 0.06 & 6.7 \\
\hline Gilia filiformis & 0 & 5.5 \\
\hline Monoptilon bellidiforme & 0.02 & 4.5 \\
\hline Chaenactis stevioides & 0.01 & 4.0 \\
\hline Descurainia pinnata & 0.38 & 3.8 \\
\hline Linanthus demissus & 0 & 3.5 \\
\hline Cryptantha nevadensis & 0.03 & 3.4 \\
\hline Eriogonum trichopes & 4 & 2.0 \\
\hline Camissonia claviformis & 0.38 & 2.0 \\
\hline Mentzelia albicaulis & 0.75 & 2.0 \\
\hline Cryptantha pterocarya & 0.03 & 2.0 \\
\hline Ipomopsis polycladon & 0.38 & 1.5 \\
\hline Vutpia octoflora & 0.12 & 1.2 \\
\hline Eschscho7zia g7yptosperma & 0.03 & 1.0 \\
\hline Chaenactis carphoclinia & 0.04 & 0.75 \\
\hline
\end{tabular}




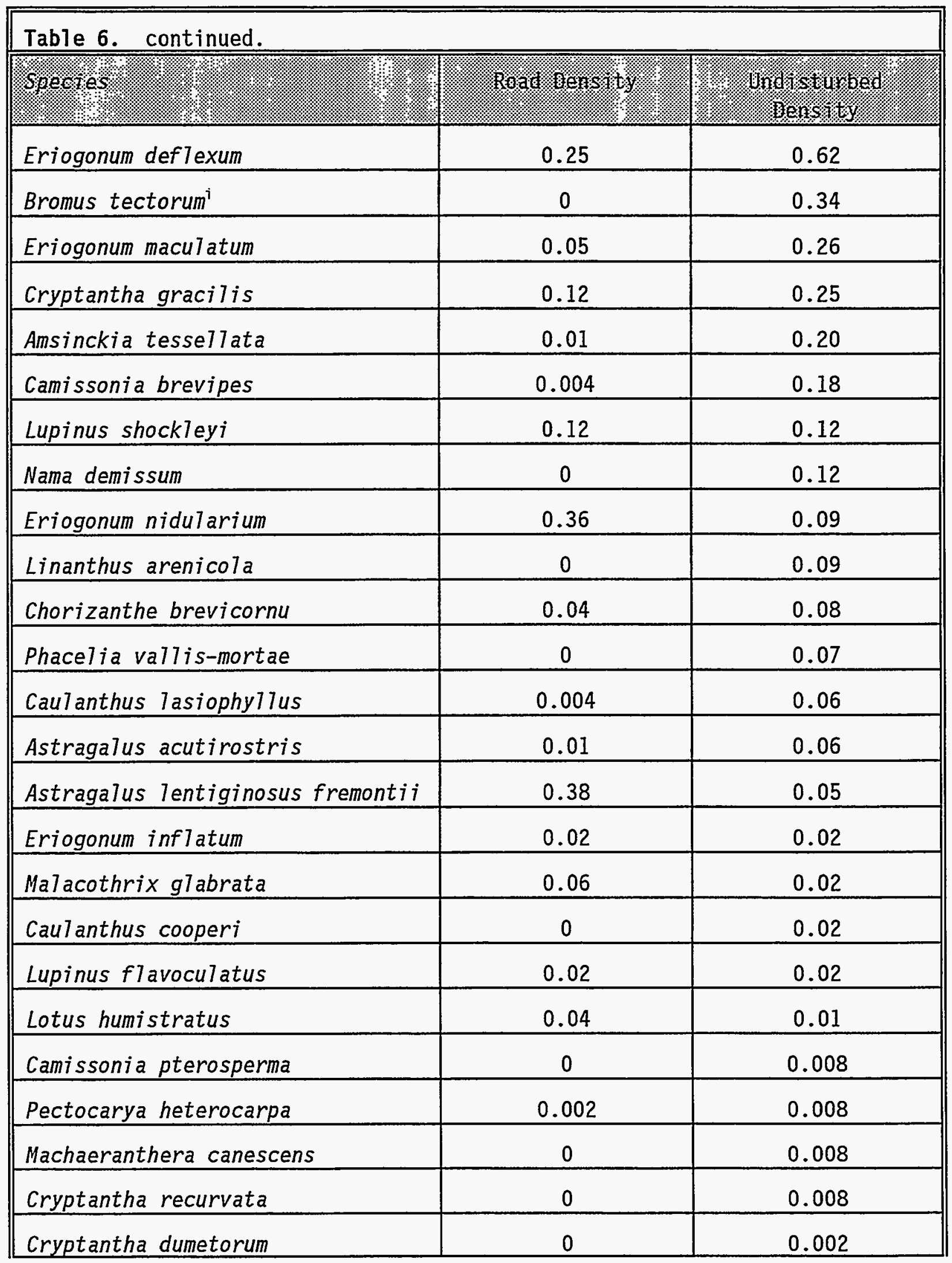




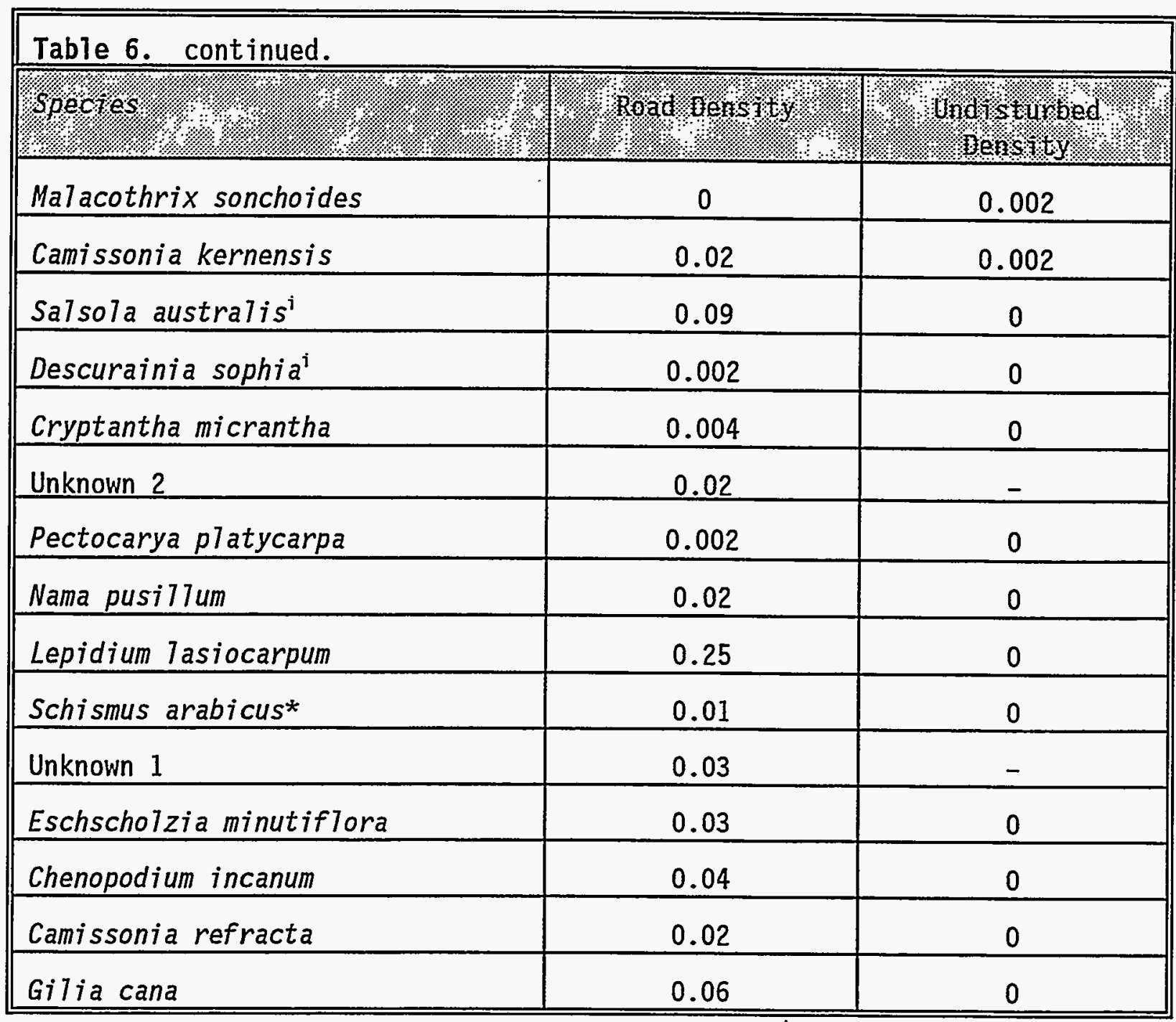

Table 7. Biomass $\left(\mathrm{g} / \mathrm{m}^{2}\right)$ and mean plant size $(\mathrm{mg})$ of common ephemeral $\mathrm{plant}$ species on the dirt road to the DAF water tank and adjacent undisturbed site. Biomass was not determined on low-density species $(-)$.

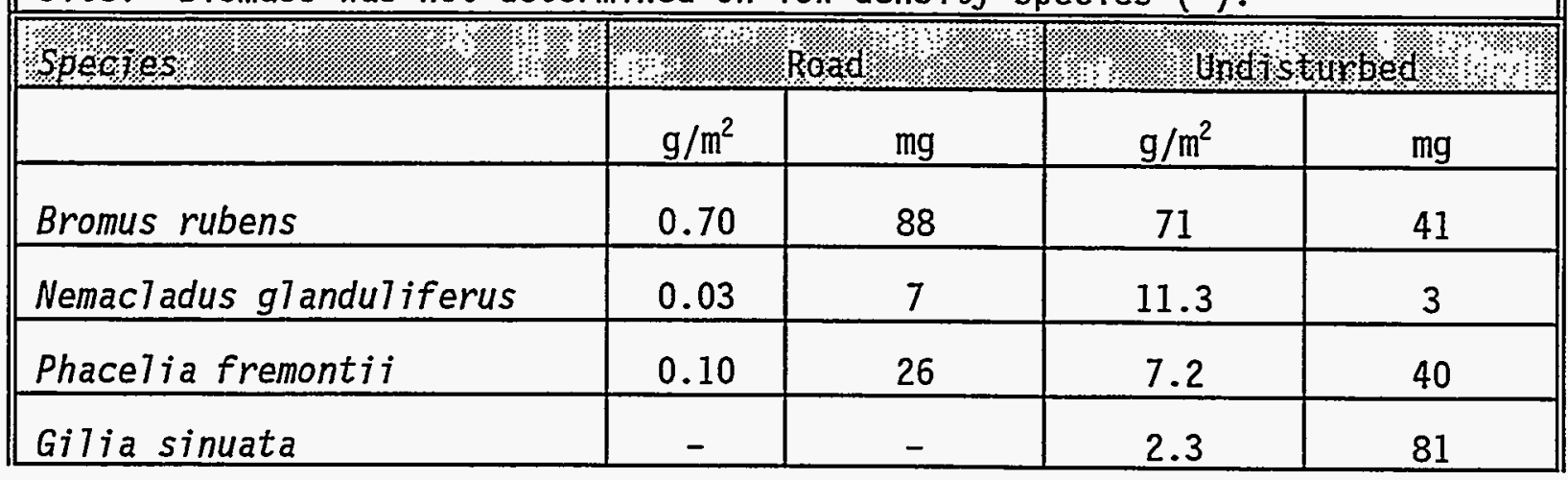




\begin{tabular}{||l|c|c|c|c||}
\hline Table 7. continued. & \\
\hline S.pectes. & \\
\hline Gilia transmontana & - & - & 1.08 & 90 \\
\hline Cryptantha circumscissa & - & - & 0.97 & 48 \\
\hline Erodium cicutarium & - & - & 0.85 & 127 \\
\hline Linanthus dichotomus & - & - & 0.75 & 20 \\
\hline Linanthus demissus & - & - & 0.53 & 15 \\
\hline Eschscholzia glyptosperma & - & - & 0.27 & 27 \\
\hline Camissonia claviformis & - & - & 0.12 & 59 \\
\hline Mentzelia albicauljs & - & - & 0.10 & 52 \\
\hline
\end{tabular}

\section{PERENNIAL PLANTS}

The perennial plant community around the DAF was characterized by census results from the $100-5 \times 2 \mathrm{~m}$ transects (Table 8 ). By volume and cover the dominant species was Larrea tridentata (creosotebush; LARTRI), a very droughthardy evergreen shrub found throughout the deserts of the American southwest. On the NTS it is dominant on the southern portions, but north of Frenchman Flat it occurs only in patches where it is somewhat protected from frost-ki11 (Beatley 1974a, 1975). It was accompanied by a co-dominant shrub, Ambrosia dumosa (white bursage, AMBDUM), which is drought-deciduous. The DAF is Tocated very close to the northern Timits of Larrea and Ambrosia, where they are replaced by mixed shrubs in a transition zone between the Mojave and Great Basin deserts (Beatley 1976). This was also near the northern 7 imit of Krameria parvifolia, (littleleaf krameria; KRAPAR), on the NTS.

In terms of biomass, the area around the DAF was dominated by Yucca brevifolia (Joshua tree; YUCBRE), a tree-like succulent which survives drought by storing water in its trunk and leaves. It is normally found in the Mojave and transition deserts at higher elevations, on rocky soils, and significant slopes. The DAF was constructed at the southern boundary of its distribution on the NTS (Beatley 1976). Perennial plant numbers were dominated by a small grass, Erioneuron pulche77um (fluffgrass false-tridens; ERIPUL), most of which germinated in 1992 and 1993. Another species contributing significant cover 
and numbers was Sphaeralcea ambigua (Desert globemallow; SPHAMB), an herbaceous perennial that also germinated and grew during the last two years. The remaining two species in Table 8 were Ephedra nevadensis (Nevada ephedra; EPHNEV), a drought hardy plant which is nearly ubiquitous on the NTS, and prefers c0ol weather, and Krameria parvifolia a low Mojave Desert shrub which grows during hot weather.

Table 8. Dominant perennial plant species near the DAF. The columns give data for the five most-dominant species in terms of live volume (1), cover $\left(\mathrm{m}^{2}\right)$, biomass $(\mathrm{Kg})$, or numbers per $1000 \mathrm{~m}^{2}$. Totals summarize results for a11 perennial species combined.

\begin{tabular}{|c|c|c|c|c|c|c|c|}
\hline$\% 81,110$ & olutine: & 18110 & ass & 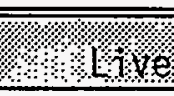 & $\theta$ & \%दिए & tor:s: \\
\hline Species & liters & Species & $\mathrm{Kg}$ & Species & $\mathrm{m}^{2}$ & Species & $n$ \\
\hline LARTRI & 41,299 & YUCBRE & 564 & LARTRI & 47 & ERIPUL & 5831 \\
\hline YUCBRE & 22,813 & LARTRI & 53.7 & KRAPAR & 28 & AMBDUM & 159 \\
\hline AMBDUM & 8,441 & AMBDUM & 21.1 & AMBDUM & 24 & SPHAMB & 106 \\
\hline KRAPAR & 8,168 & KRAPAR & 16.4 & SPHAMB & 8.4 & KRAPAR & 84 \\
\hline EPHNEV & 4,427 & EPHNEV & 6.2 & ERIPUL & 7.7 & LARTRI & 77 \\
\hline $\begin{array}{l}\text { Total } \\
\text { Tive }\end{array}$ & 94,919 & & 678 & & 141 & & 6407 \\
\hline $\begin{array}{l}\text { Total } \\
\text { dead }\end{array}$ & 37,255 & & - & & 95 & & 4100 \\
\hline
\end{tabular}

Other perennial plant species found in the $100 \mathrm{plots}\left(1000 \mathrm{~m}^{2}\right.$ of transect) around the DAF are listed in Table 9. The total of 23 species is low, as Beatley (1976) cited a range of 20 to 75 species found on $1000 \mathrm{~m}^{2}$. Species common on the NTS and which could be expected in the DAF area also include Atriplex canescens, Hymenoc7ea salsola, and Lepidium fremontii. Other species which were seen near the DAF included Mirabilis bigelovii and a seedling Pinus monophyl7a (pinyon pine). Excluding herbaceous perennials, whose populations vary greatly with rainfal1, there were 447 live and 640 dead shrubs on the $1000 \mathrm{~m}^{2}$ censused. 
Table 9. Perennial plant species found on $100,10 \mathrm{~m}^{2}$ transects, total live volumes by species (liters per $1000 \mathrm{~m}^{2}$ ), and the desert affinity (Mojave = M, Transition $=T$, Great Basin $=G$ ) for each species.

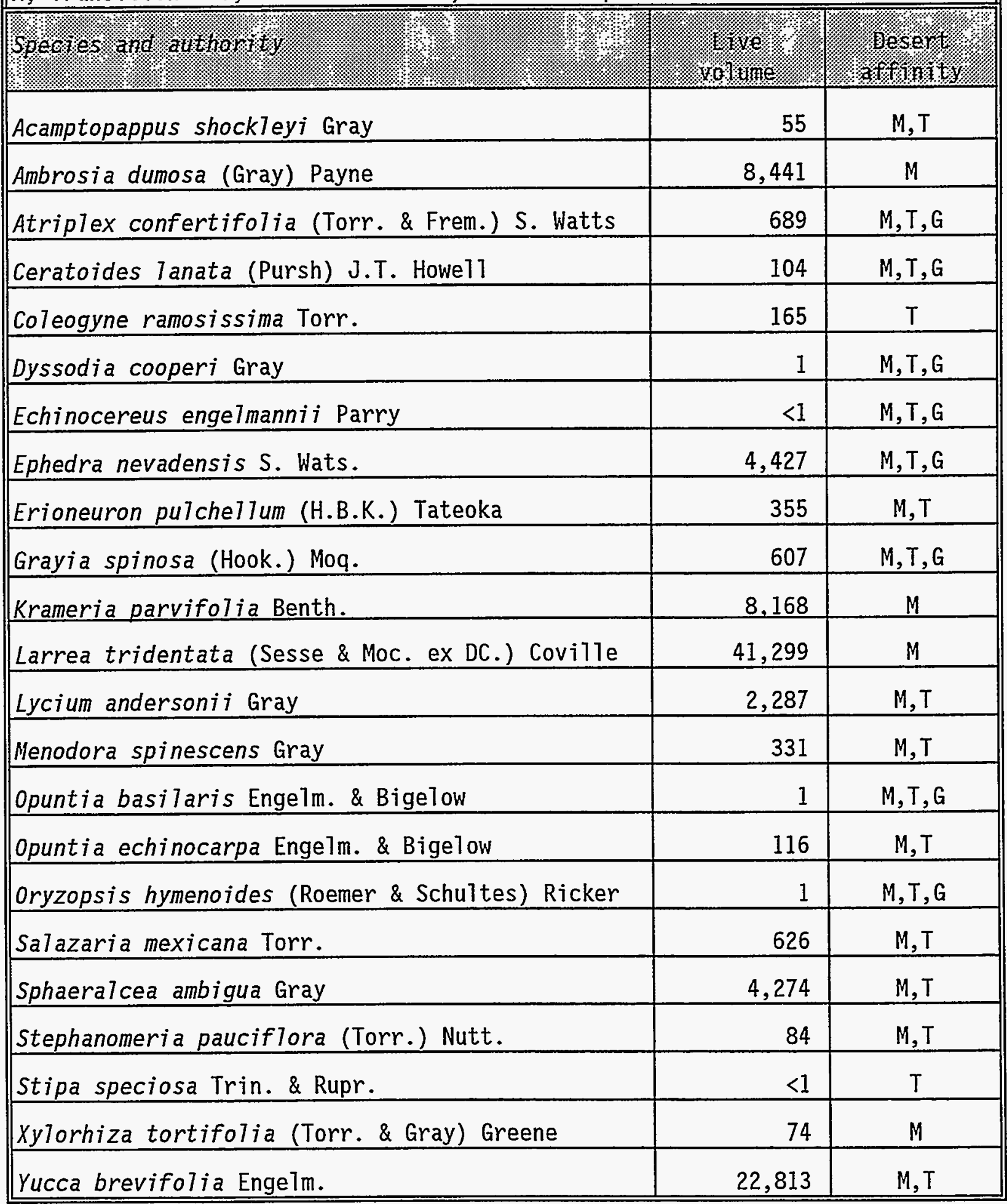




\section{Effects of the DAF on Perennial Plants}

Transects were placed at different distances from the DAF to monitor changes occurring near the DAF. There were some differences in the perennial plants associated with distance from the DAF, primarily in the density of live shrubs. With all shrubs from all plots lumped together, the proportion of live to dead shrubs censused in $200 \mathrm{~m}^{2}$ differed among the five sampled distances (Table 10; $X^{2}=13.1,4$ d.f., $P=0.011$ ), as did the proportion of live to dead herbs $\left(X^{2}=694,4\right.$ d.f., $\left.P<0.001\right)$.

Table 10. Gross perennial plant population patterns at increasing distances

\begin{tabular}{|c|c|c|c|c|c|}
\hline Tritanes. & $\%$ & ॠः. & 1. $10.90 \mathrm{ss}$ & $9 \operatorname{lross} 25$ & 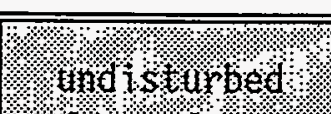 \\
\hline (metequs): & 1.11508 .9 & $9 \mathrm{dead}$ & .1 .1 .0 & 1.00 & dersitet. shrto se \\
\hline $0-300$ & 46 & 41 & 723 & 117 & $4.6+2.4$ \\
\hline $300-400$ & 88 & 129 & 1454 & 965 & $6.5+2.0$ \\
\hline $400-500$ & 74 & 130 & 1538 & 431 & $4.9+1.4$ \\
\hline $500-600$ & 124 & 141 & 1297 & 781 & $6.8+2.6$ \\
\hline $1000-1500$ & 115 & 199 & 948 & 1166 & $6.8+2.2$ \\
\hline
\end{tabular}

Numbers of Tive shrubs found per $10 \mathrm{~m}^{2}$ plot increased with distance from the DAF (ANOVA, $F_{4.95}=2.44, P=0.052$ ), as did the number of dead shrubs per plot (ANOVA, $F_{4.95}=2.96, P=0.024$ ). Considering only undisturbed plots, there were no significant differences with distance from the DAF in numbers of 7 ive or dead shrubs or herbs per plot (ANOVA, maximum $F_{4,261}=1.39, P=0.248$ ) suggesting differences were related to the greater disturbance near the DAF.

Four species were numerous enough to test for effects of distance from the DAF. Larrea tridentata and Krameria parvifolia volumes did not vary with distance (ANOVA, $F_{4.72}=1.51, P=0.208 ; F_{4.79}=1.34, P=0.263$ respectively). However, the volumes of Ambrosia dumosa increased with distance between the 0 - $300 \mathrm{~m}$ band of plots and the $500-600 \mathrm{~m}$ band (ANOVA, $F_{4.154}=4.52, P=$ 0.002 ), and the volumes of Sphaeralcea ambigua varied significantly among the different distances (ANOVA, $F_{4.101}=3.84, P=0.006$ ) (Table 11). 
Table 11. Mean volumes (7iters \pm 2 se) of the most common shrubs near the DAF and their variation with distance (m) from the DAF in summer 1993.

\begin{tabular}{|c|c|c|c|c|c|c|c|c|}
\hline \$ & 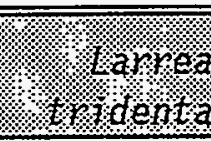 & & (1) 1 remer & & ingeros & & garaera & 4 \\
\hline (m) & vol & $\mathrm{n}$ & vol & $n$ & vol & $n$ & vol & $\mathrm{n}$ \\
\hline $0-300$ & $599+329$ & 10 & $73+66$ & 8 & $34+22$ & 24 & $82+82$ & 12 \\
\hline $301-400$ & $446+286$ & 19 & $70+30$ & 22 & $43+20$ & 28 & $4+4$ & 6 \\
\hline $401-500$ & $583+353$ & 12 & $85+33$ & 19 & $71+25$ & 29 & $72+42$ & 25 \\
\hline $501-600$ & $360+139$ & 24 & $140+69$ & 17 & $93+43$ & 25 & $37+17$ & 35 \\
\hline $1000-1500$ & $933+734$ & 12 & $114+63$ & 18 & $38+11$ & 53 & $6+4$ & 28 \\
\hline
\end{tabular}

Ambrosia dumosa in the band closest to the DAF were concentrated in two plots (5-1 and 12-1), which held 19 of the 24 plants censused. Eight of the smallest plants were in a clump containing one large live and two large dead Ambrosia, on a plot (12-1) $16 \mathrm{~m}$ west of a large scraped and graveled area south of the DAF. Those were probably seedlings that germinated in 1992 and survived in 1993 in a crowded and shaded microhabitat. The nearby scraped and graveled area may have enhanced survival or germination due to water used for dust control or water buitt up in the vicinity by the absence of vegetation and the presence of a thick gravel mulch.

Sphaeralcea ambigua is a species which occasionally invades disturbed areas on the NTS. It is normally present in undisturbed vegetation as small plants which grow 7 arge and reproduce only in wet years such as 1993. It was not seen in 1993 on scraped areas, but the greater sizes seen near the DAF could be partialiy related to the shorter distances to disturbance. $S$. ambigua distribution of sizes and numbers was complex and patchy, and may have been affected by soil variation and recent drought kill of other species.

\section{Disturbances}

Disturbances around the DAF were extensive. From the perimeter fence to $600 \mathrm{~m}$ from the front door, the flood-control dike and bladed roads leading to and around it were the DAF-related disturbances with the widest distribution (Table 12). Most of the disturbances within $600 \mathrm{~m}$ of the DAF were DAF-related 
(Table 13). As distance increased proportionately more non-DAF disturbances were encountered. Mean distance to nearest disturbance differed among the five bands (Kruskal Wallis, $H=26.3$, d.f. $=4, P=0.0001$ ), increasing from 8 $\mathrm{m}$ within $300 \mathrm{~m}$ of the DAF to $180 \mathrm{~m}$ between 1 and $1.5 \mathrm{~km}$ (Table 13).

\begin{tabular}{|c|c|}
\hline Gisturbance & 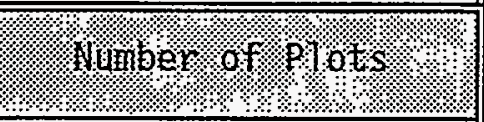 \\
\hline Flood dike and associated roads & 21 \\
\hline Miscellaneous DAF-related scraped areas & 17 \\
\hline Dirt roads associated with 1950 's testing & 13 \\
\hline DAF water tank and associated roads & 12 \\
\hline Scraped areas immediateTy surrounding DAF fence & 12 \\
\hline DAF sewage pond, and associated road and pipel ine & 8 \\
\hline Transmitter station, road and buried cables & 8 \\
\hline Paved road to DAF & 5 \\
\hline Other non-DAF disturbances & 2 \\
\hline
\end{tabular}

Table 13. Mean distances to nearest disturbances, and type of disturbance, within five bands at varying distances from the DAF.

\begin{tabular}{|c|c|c|c|}
\hline 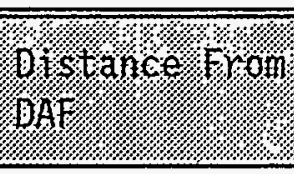 & 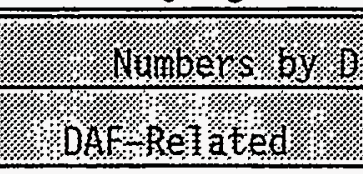 & 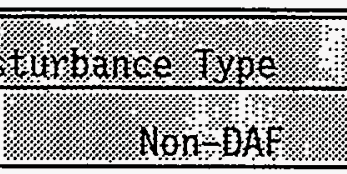 & 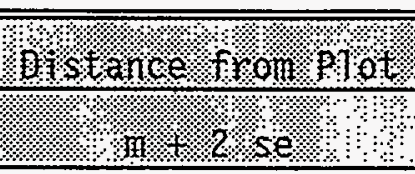 \\
\hline $0-300 m$ & 20 & 0 & $8+7$ \\
\hline $301-400 m$ & 18 & 1 & $24+20$ \\
\hline $401-500 \mathrm{~m}$ & 17 & 3 & $53+27$ \\
\hline $501-600 m$ & 15 & 5 & $67+31$ \\
\hline $1000-1500 m$ & 2 & 17 & $180+42$ \\
\hline
\end{tabular}




\section{Sensitive Perennial Plants}

There are no woody vascular plants on the NTS Tisted as endangered, threatened, or candidates for those listings. Sensitive species on the NTS are all herbaceous ephemerals or short-lived perennials. If seen, they would have been reported under ephemeral plant studies.

\section{REPTILES}

\section{Roadside Studies}

\section{Spring Samples}

Average number of side-blotched lizards using plots each day was lower on roadside plots (trts 1 and 2 pooled, $12.8 \pm 1.8, \bar{x} \pm 2$ se/ha) than on control plots $\left(28.3 \pm 2.8 /\right.$ ha, $F_{1.18}=11.05, P=0.004$, Fig. 9). Similarly, total number of individuals using roadside plots $(2.8 \pm 0.3 / \mathrm{p} 1$ ot $)$ was fewer than that using control plots $\left(6.5 \pm 0.6 / p 1\right.$ ot, $\left.F_{1.18}=32.3, P=0.00002\right)$. Average SVL did not differ between 1 izards occupying roadside $(42.6 \pm 2.68 \mathrm{~mm}, \overline{\mathrm{x}} \pm 2$ se), or control plots $\left(42.1 \pm 1.22 \mathrm{~mm}, \mathrm{~F}_{1.18}=0.09, \mathrm{P}=0.77\right)$. Average weight also did not differ between roadside $(2.37 \pm 0.32 \mathrm{~g})$ and control plots $(2.35$ $\left.\pm 0.18, F_{1.18}=0.02, P=0.90\right)$. Females were a higher proportion of the population along the roadside $(64.2 \pm 14 \%)$, than in the control plots $(42.1 \pm$ $\left.6 \%, F_{1.18}=5.98, P=0.025\right)$. Age class composition did not differ between roadside $(75 \%<1 \mathrm{yr}, 25 \% 1 \mathrm{yr}, 0 \%>1 \mathrm{yr})$ and control areas $(88 \%<1 \mathrm{yr}, 12 \% 1$ $\mathrm{yr}, 0 \%>1 \mathrm{yr}$, chi square $=2.49,1 \mathrm{~d} . \mathrm{f} ., \mathrm{P}>0.10)$.

There were differences in average number of lizards using each treatment $\left(F_{2.27}\right.$ $=17.7, P=0.00001$, Fig. 10) with no side-blotched lizards using the first 10 $m$ from the center of the road (area of negative effect), many $(25.5 \pm 3.5 /$ ha) using the next $10 \mathrm{~m}$ (area with potential positive effect), and the control area $(28.3 \pm 2.8 / \mathrm{ha})$ well removed from the road. Total number of individual Uta seen per five day period per plot differed across the three treatments $\left(F_{2.27}=39.5, P<0.0001\right)$. Total number of 1 izards per plot in the area from 0 to $10 \mathrm{~m}$ from road center was zero, total number in the area from 10 to $20 \mathrm{~m}$ from road center was $5.6 \pm 0.6 / \mathrm{plot}$, and number on control plots was $6.5 \pm$ $0.6 /$ plot. Comparisons across a11 three treatments are not possible for the other characters discussed above because treatment 1 (area within $10 \mathrm{~m}$ of the center of the road, or area of potential negative effect) contained no Uta. Statistical results presented above for SVL, weight, and proportion of 
females in the population, do hold for comparisons between treatment 2 (area 10 to $20 \mathrm{~m}$ from road center) and treatment 3 (control plots). Probability of recapture from spring to summer surveys was greater in the control area $(25.4 \%)$ than on the roadside $(7.1 \%$, chi square $=3.99,1 \mathrm{~d} . f ., P=0.046)$.

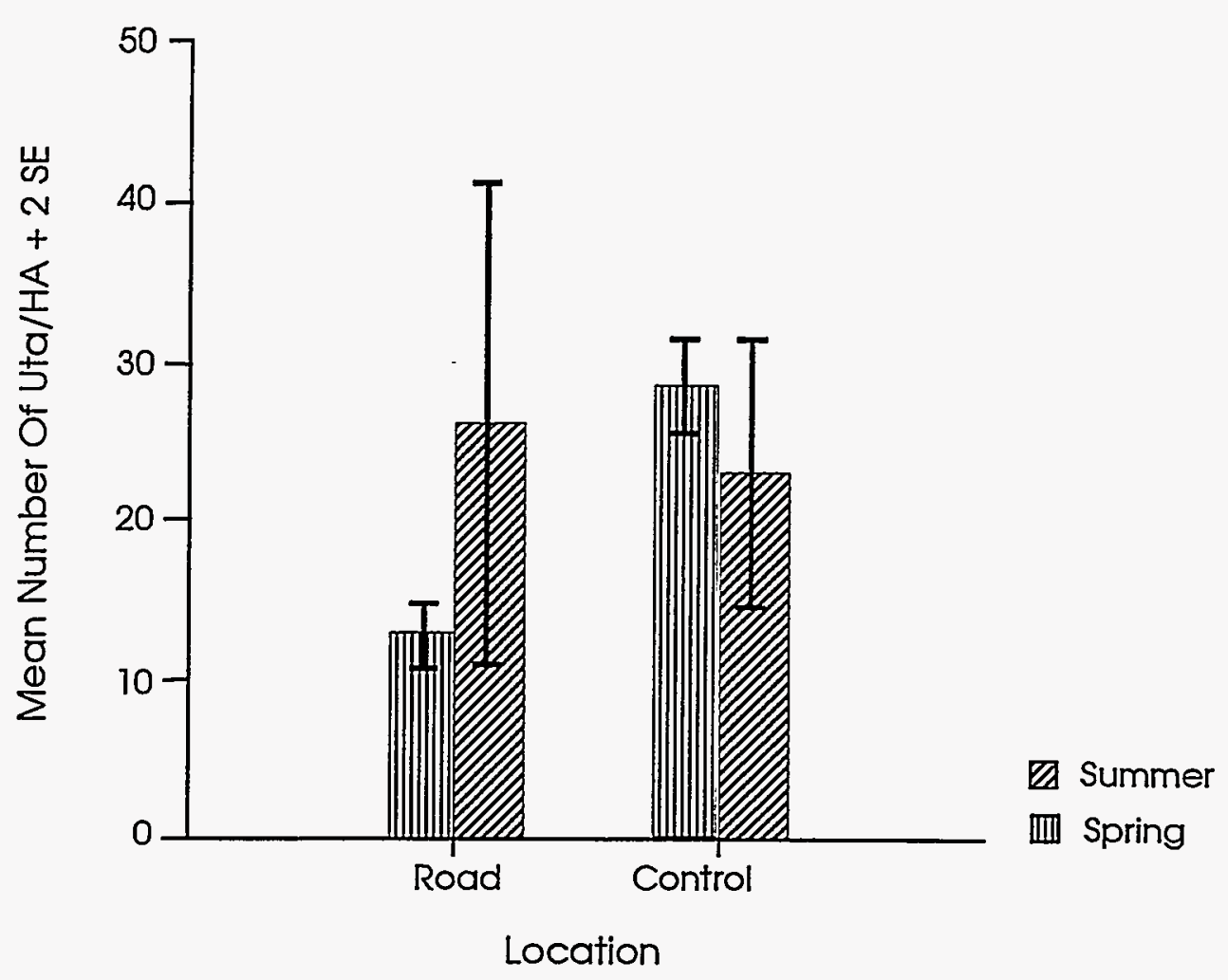

Figure 9 - Mean number of side-blotched lizards/ha seen on roadside or control plots near the DAF in spring and summer 1993.

\section{Summer Samples}

In summer, average number of side-blotched lizards present did not differ between roadside $(26.0 \pm 15.3 / \mathrm{ha})$ and control plots $\left(22.8 \pm 8.7 / \mathrm{ha}, \mathrm{F}_{1.18}=\right.$ $0.34, P=0.57$, Fig. 9). Similarly, number of individuals marked per plot over five days did not differ between roadside $(6.6 \pm 2.4 / \mathrm{plot})$ and control plots $\left(5.9 \pm 1.1 / \mathrm{p} 7\right.$ ot, $\left.F_{1.18}=0.29, P=0.598\right)$. Average SVL did not differ between side-blotched lizards occupying roadside $(33.9 \pm 2.9 \mathrm{~mm})$ or control areas $\left(36.8 \pm 3.2 \mathrm{~mm}, F_{1.18}=1.83, P=0.19\right)$. Average body weights were heavier for side-blotched lizards in control areas $(1.96 \pm 0.33 \mathrm{~g})$ than in roadside areas $\left(1.42 \pm 0.35 \mathrm{~g}, F_{1.18}=5.13, P=0.036\right)$. Proportion of the 
population that was female did not differ between roadside $(44.8 \pm 15.0 \%)$ and control areas $\left(58.2 \pm 3.3 \%, F_{1.18}=0.95, P=0.343\right)$. Age composition of sideb7otched lizards again did not differ between treatments (roadside $71.4 \%<1$, $22.1 \% 1,6.5 \%>1$; control $53.5 \%<1,36.2 \% 1,10.3 \%>1 ; X^{2}=4.66,2$ d.f., $\mathrm{P}=0.098)$.

Average number of side-blotched lizards present per day differed greatly across the three areas $\left(F_{2.27}=19.5, P<0.0001\right.$, Fig. $10,1-10 \mathrm{~m}$ from road center $=$ none, $10-20 \mathrm{~m}=52.0 \pm 19.3 / \mathrm{ha}$, control $=22.75 \pm 5.5 / \mathrm{ha})$. Number of individual side-blotched lizards seen per plot over five days also differed across al1 treatments $\left(F_{2.27}=22.4, P<0.0001\right)$. The area from $0-10 \mathrm{~m}$ from the road contained no side-blotched lizards, $10-20 \mathrm{~m}$ contained $13.2 \pm 4.7 / \mathrm{plot}$, and control areas contained $5.9 \pm 1.1 / \mathrm{p}$ lot).

Spearman rank correlations between distance from the DAF building and lizard traits were all nonsignificant for both 7 ines (Table 14). Eight perennial plant species were encountered commonly enough in roadside or control areas to merit comparison. Six of eight species had different distributions across treatments, with the roadside treatment always differing from the other treatments (Table 15). Roadside graded areas also had fewer total Tive perennials relative to the other two areas. Total number of live perennials and number of shrub species most typically did not differ between the berm area (10 - $20 \mathrm{~m}$ from the road center) and the control area (Table 15). These plant patterns mimic those for number of lizards observed. 


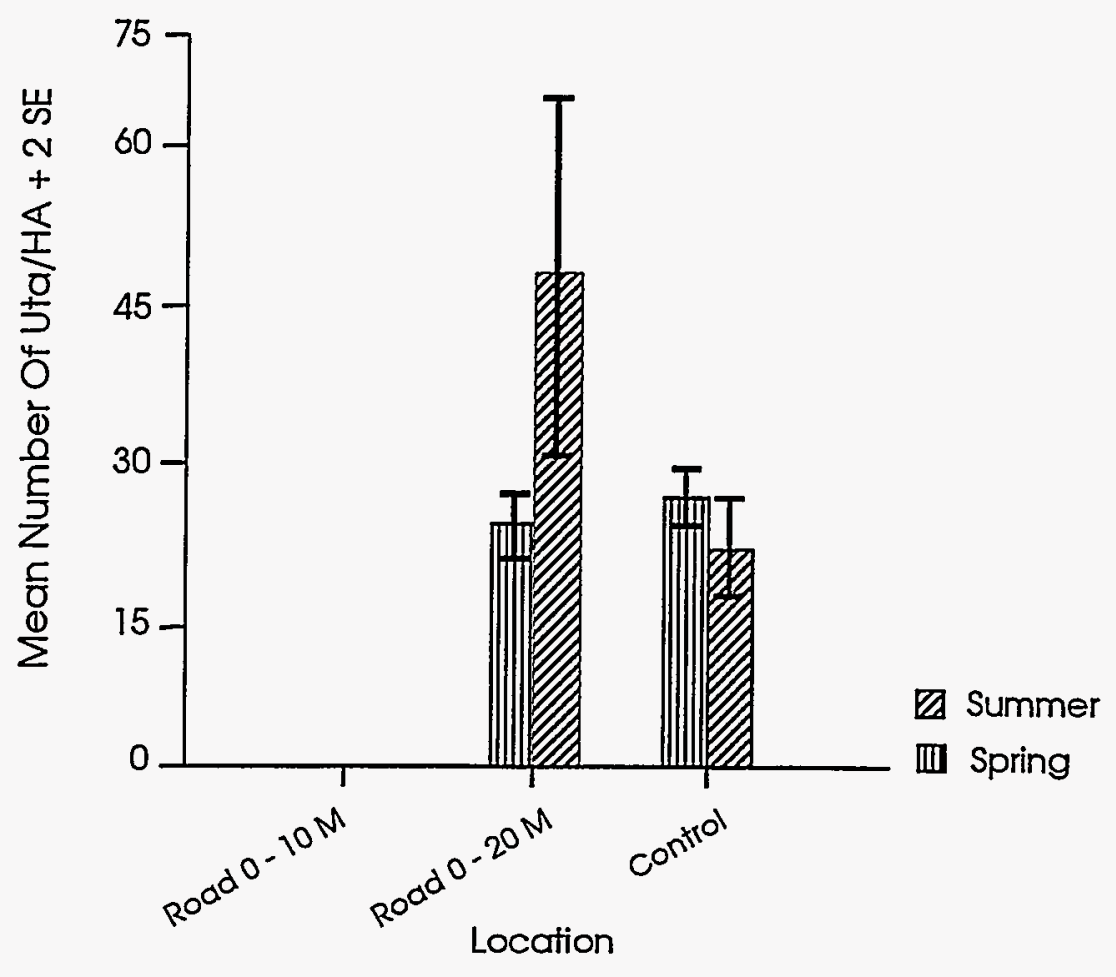

Figure 10 - Mean number of side-blotched lizards/ha seen from 0 to $10 \mathrm{~m}$ or 10 to $20 \mathrm{~m}$ from road center, or control plots near the DAF in spring and summer 1993.

Table 14. Spearman's rank correlations between plot location (= distance from DAF buildings) and traits of side-blotched lizards. All samples have 8 degrees of freedom.

\begin{tabular}{|l|c|c|}
\hline & \multicolumn{1}{|c|}{ Roadside } & Control \\
\hline & $0.275, \mathrm{P}>0.05$ & $0.146, \mathrm{P}>0.05$ \\
\hline Mean Number Present/Day & $0.353, \mathrm{P}>0.05$ & $0.331, \mathrm{P}>0.05$ \\
\hline $\begin{array}{l}\text { Total Number of } \\
\text { Individuals present }\end{array}$ & $0.297, \mathrm{P}>0.05$ & $0.091, \mathrm{P}>0.05$ \\
\hline Mean SVL (mm) & $0.285, \mathrm{P}>0.05$ & $0.097, \mathrm{P}>0.05$ \\
\hline Mean weight (g) & $-0.485, \mathrm{P}>0.05$ & $0.518, \mathrm{P}>0.05$ \\
\hline $\begin{array}{l}\text { Proportion female in } \\
\text { population }\end{array}$ & & \\
\hline
\end{tabular}




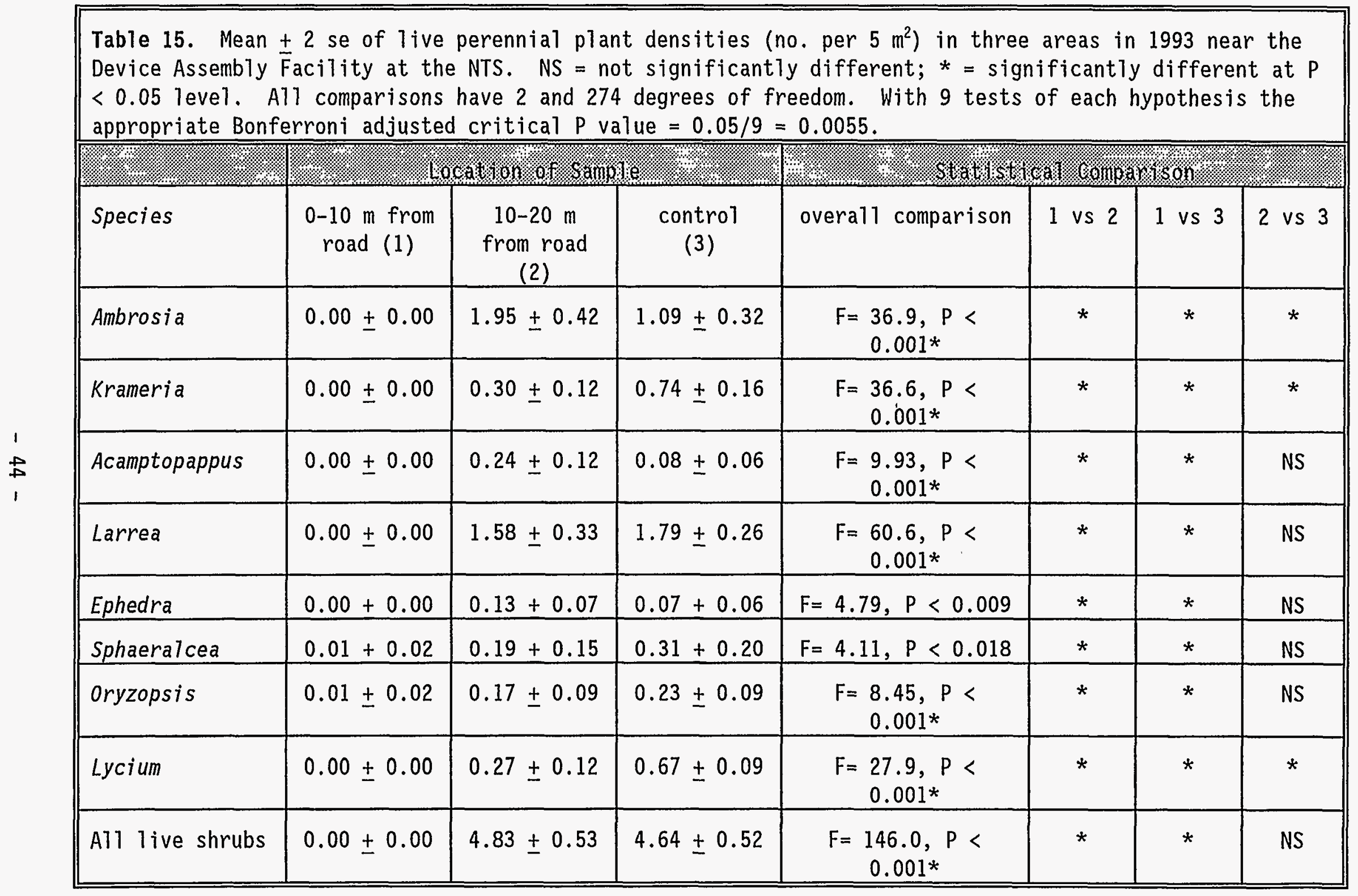


DAF Tizard plots were smal1 ( 0.08 ha for roadside studies) and undoubtedly there was much movement on and off plots because of their small size relative to 7 izard home range sizes. Numbers present per plot and number of recaptures were too low to facilitate mark-recapture studies. Therefore, number of lizards caught or observed was summed and used to represent lizard abundance. Observational counts like these can be influenced by visibility which can in turn be influenced by habitat characteristics. The control areas had much thicker and structuraliy more complex vegetation relative to either the DAF ditch or the roadside area. The berm area along the road was intermediate in these regards between the roadside and its control area. Differences in vegetational complexity between areas typically ran counter to observed differences in lizard abundances - that is, the higher counts came from the complex areas and the low counts from the simple areas where visibility is presumably greater. Because individuals were marked with paint patterns, recaptures were achieved simply by recording paint patterns observed. An index of recapture probability (number of observed recaptures/number of potential recaptures) was constructed to compare recapture rates across areas. Recapture rates did not differ between control areas or the berm in either the spring (control $32.6 \%$, berm $37.7 \%, X^{2}=0.38,1$ d.f., $P=0.54$ ) or summer (control 13.2\%, berm $17.3 \%, X^{2}=0.69,1$ d.f., $P$ 0.41) suggesting that visual biases were not an important factor contributing to differences in counts of side-b7otched Tizards.

\section{Diversion Ditch Studies}

\section{Spring Samples}

Ca77isaurus were more abundant in the ditch $\left(23.0 \pm 3.3 / \mathrm{ha}, \mathrm{F}_{1.88}=78.04, \mathrm{P}<\right.$ 0.0001 , Fig. 11) than in the undisturbed control area $(1.7 \pm 0.5 / \mathrm{ha})$. Number of Uta observed per plot per day was greater on pooled control plots (17.7 \pm $2.5 / \mathrm{ha}, \bar{x} \pm 2$ se, $F_{1.88}=23.48, P<0.0001$, Fig.12) than in the ditch in the DAF disturbed area $(0.7 \pm 0.7 / \mathrm{ha})$. Number of Cnemidophorus seen per day per plot was also greater in the undisturbed control area $\left(13.3 \pm 1.8 / \mathrm{ha}, F_{1.88}=\right.$ 26.02, $P<0.0001)$ relative to the disturbed ditch area $(0.3 \pm 0.3 / \mathrm{ha})$. 


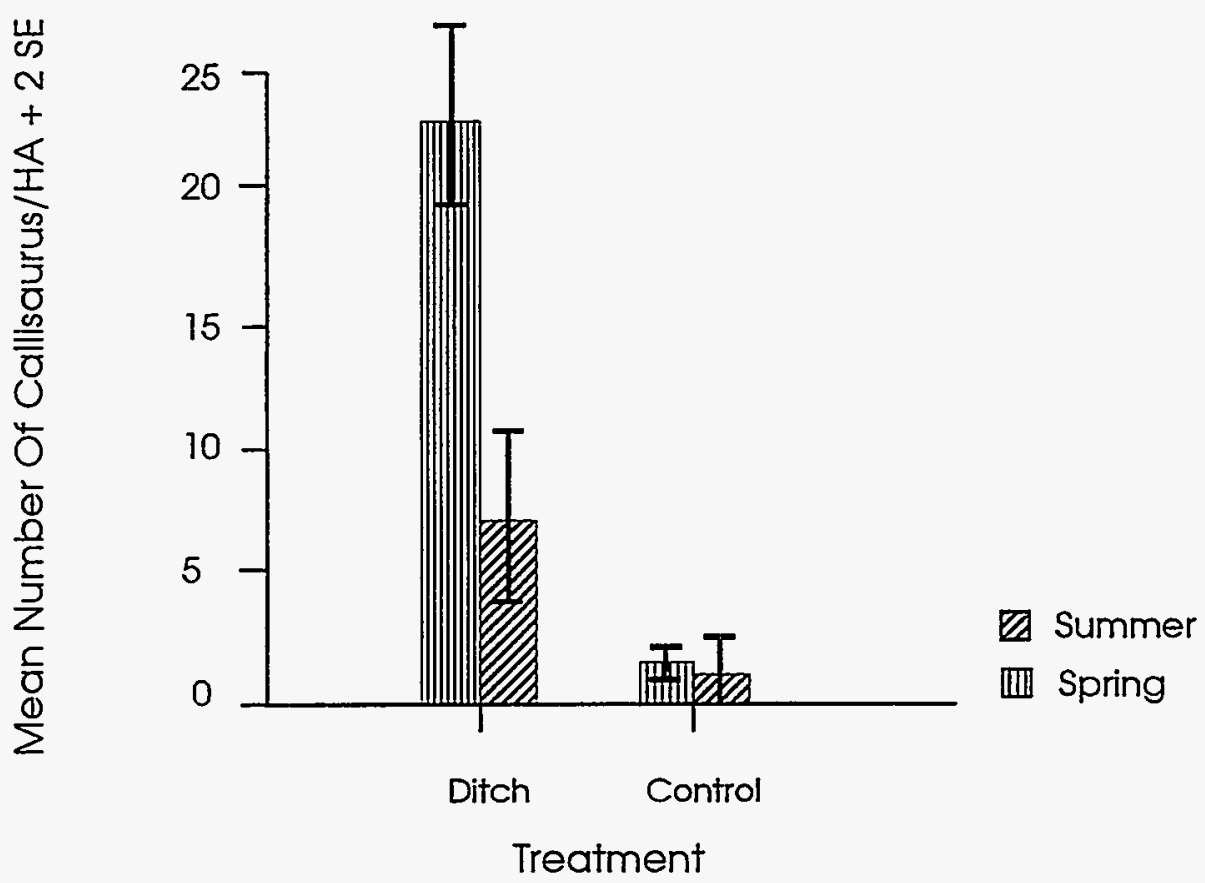

Figure 11 - Mean number of zebra-tailed lizards/ha seen in the DAF diversion ditch and nearby controls during spring and summer 1993.

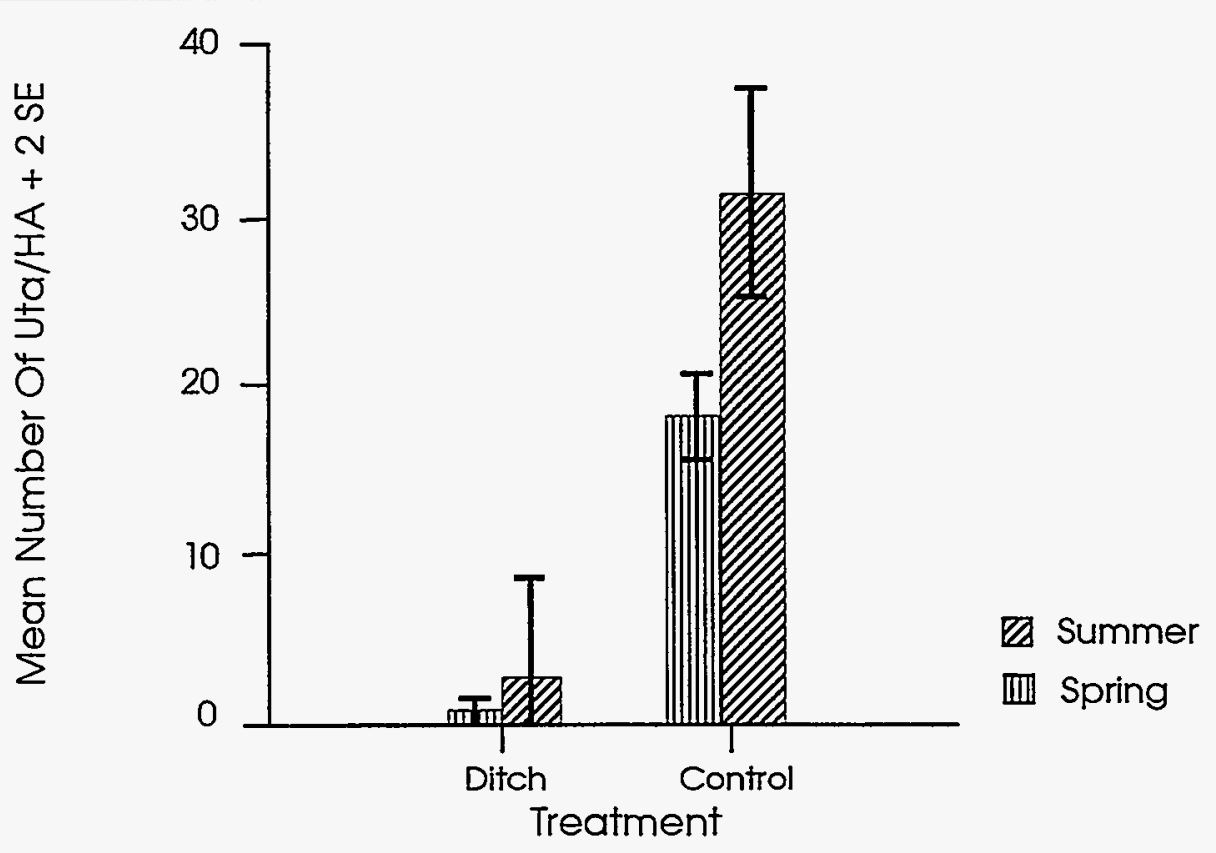

Figure 12 - Mean number of side-bTotched lizards/ha seen in the DAF diversion ditch and control plots in spring and summer 1993. 
Approximately twice as many lizard species were observed per plot on the control area $\left(1.7 \pm 0.1, F_{1.88}=21.96, P<0.0001\right)$ as in the ditch $(0.9 \pm$ $0.1)$. More lizards were observed per plot in control areas $(34.2 \pm 3.0 /$ ha, $\left.F_{1.88}=4.23, P=0.043\right)$ than in the ditch $(24.3 \pm 3.3 / \mathrm{ha})$. Lizard faunas of the two areas were so different (the control lizard community consisted mainly of Uta, the ditch mainly Cal7isaurus) that it was impossible to make intraspecific comparisons of individual lizard traits between disturbed and control areas.

Number of side-blotched lizards seen per plot per day differed across al 1 three treatments $\left(F_{2.87}=15.7, P<0.0001\right.$; flats $13.0 \pm 5.0 /$ ha; arroyo bottoms $23.0 \pm 8.0 / \mathrm{ha}$; DAF ditch $1.0 \pm 1.0 / \mathrm{ha})$. Number of whiptail 7 izards did not differ between plots in flats $(11.0 \pm 5.0 / \mathrm{ha})$ or plots in arroyo bottoms $(15.0 \pm 6.0 / \mathrm{ha})$ but both did differ from the DAF ditch $\left(0.3 \pm 1.8 / \mathrm{ha}, \mathrm{F}_{2.87}=\right.$ $14.1, P<0.0001)$. Zebra-tailed Tizards were more abundant in the DAF ditch $(23.0 \pm 7.0 / \mathrm{ha})$ than in flats $(1.0 \pm 1.0 / \mathrm{ha})$ or arroyo bottoms $(3.0 \pm 2.0 / \mathrm{ha}$, $\left.F_{2.87}=39.1, P<0.0001\right)$. Total number of species seen per plot also differed across treatments $\left(F_{2.87}=12.0, P<0.0001\right)$, with $f 1$ at $(1.6 \pm 0.3)$ and arroyo bottom plots $(1.8 \pm 0.3)$ containing more species than plots in the DAF ditch $(0.9 \pm 0.2)$. Final7y, number of individual Tizards seen per plot differed across treatments $\left(F_{2,87}=6.7, P=0.002\right)$, with flats $(26.0 \pm 6.0 / \mathrm{ha})$ and arroyo bottoms $(42.0 \pm 26.0 / \mathrm{ha})$ containing more relative to the DAF ditch $24.0 \pm 18.0 / \mathrm{ha})$.

\section{Summer Samples}

Summer samples were analyzed as two way ANOVAs testing for differences across both treatment and date the sample was collected. Numbers were sufficient for comparisons of side-blotched lizards, whiptails, and zebra-tailed lizards. Number of side-blotched lizards observed per plot was greater on the pooled (flat and arroyo) control plots $(30.7 \pm 6.1 / \mathrm{ha}$ ) relative to ditch plots (2.7 \pm 5.8 /ha, Table 16, Fig. 12). Whiptail lizards were also more abundant on control plots $(6.8 \pm 3.5 / \mathrm{ha})$ relative to ditch plots $(1.0 \pm 1.1 / \mathrm{ha}$, Table 16). In contrast, zebra-tailed lizards were more abundant in ditch p7ots ( 7.3 $\pm 3.4 / \mathrm{ha}$ ) than control plots $(1.2 \pm 1.5 / \mathrm{ha}$, Table 16 , Figure 11). Control plots tended to contain more species $(1.6 \pm 0.7)$ than ditch plots $(0.8 \pm 0.7$, Table 16). They also contained more individual lizards $(40.0 \pm 22.4 / \mathrm{ha})$ relative to the ditch plots $(11.3 \pm 11.7 /$ ha, Tab7e 16). Finally, there were no differences across days in number of side-blotched lizards, number of 
whiptails, number of zebra-tailed lizards, total number of lizard species per plot, or number of individual lizards per plot (Table 16).

A closer look at location effects during the summer, revealed sizeable differences across locations for whiptails $\left(F_{2.83}=5.45, P=0.006\right)$, sideblotched lizards $\left(F_{2.83}=38.61, P<0.0001\right)$, zebra-tailed lizards $\left(F_{2.83}=\right.$ 10.16, $P<0.0001)$, number of 1izard species $\left(F_{2.83}=11.38, P<0.0001\right)$, and total number of lizard individuals seen $\left(F_{2,83}=20.89, P<0.0001\right)$. Whiptails were uncommon in the ditch $(1.0 \pm 1.1 / \mathrm{ha})$ relative to the flats $(7.3 \pm$ $3.9 / \mathrm{ha}$ ) or the arroyo bottoms $(6.3 \pm 3.0 / \mathrm{ha})$. Side-blotched lizards were also uncommon in the ditch $(2.7 \pm 5.8 / \mathrm{ha})$ relative to their numbers on the flats $(31.3 \pm 5.1 / \mathrm{ha})$, or in the arroyo bottoms $(30.0 \pm 7.0 / \mathrm{ha})$. In contrast, zebra-tailed lizards were more abundant in the ditch $(7.3 \pm 3.4 / \mathrm{ha})$ relative to the flats $(0.0 \pm 0.0 / \mathrm{ha})$, or the arroyos $(2.3 \pm 5.7 / \mathrm{ha})$. Number of lizard species per plot also differed across plots, with the ditch containing fewer species per plot $(0.8 \pm 0.7)$, than the flats $(1.6 \pm 0.3)$ or the arroyos $(1.6 \pm 0.3)$. Final7y, number of lizards seen per plot differed between the ditch $(11.3 \pm 6.1 / \mathrm{ha})$ and the flats $(40.7 \pm 7.4 / \mathrm{ha})$, or the arroyos $(39.3 \pm 9.0 / \mathrm{ha})$. In none of these comparisons did differences occur between flats and arroyos.

Table 16. ANOVA results testing for differences in Tizard parameters across sample days and treatments.

\begin{tabular}{|c|c|c|}
\hline 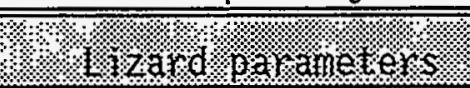 & (1/: & 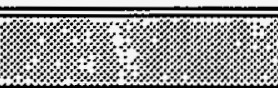 \\
\hline & Across treatments & Across dates \\
\hline $\begin{array}{l}\text { No. of side-blotched } \\
\text { lizards per plot }\end{array}$ & $\begin{array}{l}F_{1.84}=77.9 \\
P<0.0001\end{array}$ & $\begin{array}{c}F_{4.84}=0.56 \\
P=0.692\end{array}$ \\
\hline $\begin{array}{l}\text { No. of whiptails } \\
\text { per plot }\end{array}$ & $\begin{aligned} F_{1.84} & =10.77 \\
P & =0.002\end{aligned}$ & $\begin{array}{c}\mathrm{F}_{4.84}=1.03 \\
\mathrm{P}=0.397\end{array}$ \\
\hline $\begin{array}{l}\text { No. of zebra-tailed } \\
\text { lizards per plot }\end{array}$ & $\begin{array}{c}F_{1.84}=18.14 \\
P<0.0001\end{array}$ & $\begin{array}{c}F_{4.84}=0.74 \\
P=0.57\end{array}$ \\
\hline $\begin{array}{l}\text { No. of lizard species } \\
\text { per plot }\end{array}$ & $\begin{array}{c}F_{1.84}=22.99 \\
P<0.0001\end{array}$ & $\begin{array}{c}F_{4.84}=0.71 \\
P=0.587\end{array}$ \\
\hline $\begin{array}{l}\text { No. of lizard } \\
\text { individuals } \\
\text { per plot }\end{array}$ & $\begin{array}{c}F_{1.84}=42.18 \\
P<0.0001\end{array}$ & $\begin{aligned} F_{4.84} & =0.52 \\
P & =0.21\end{aligned}$ \\
\hline
\end{tabular}




\section{DAF Lizard Transects}

Whiptails, leopard lizards, side-blotched lizards, zebra-tailed lizards, and horned-lizards were seen on plots in late spring, but only two species were abundant enough for analysis. Whiptails were more often seen in vegetated areas around $20 \mathrm{~m}$ from road center $(12.0 \pm 3.3 / \mathrm{ha})$, or control areas we 11 removed from the road $(13.3 \pm 3.2 / \mathrm{ha})$, than in areas from 0 to $10 \mathrm{~m}$ from road center $(2.7 \pm 1.7 /$ ha, Kruska17-Wa77 is $H=34.91,2$ d.f., $P<0.0001)$. Sideblotched lizards were more often seen in the area approximately $20 \mathrm{~m}$ from road center $(11.6 \pm 3.4 / \mathrm{ha})$, or the control area well removed from the road (13.3 $\pm 1.5 / \mathrm{ha})$ than near the road $(0.00 \pm 0.00 / \mathrm{ha}, H=53.13,2$ d.f., $P<0.0001)$. Number of lizard species seen per $50 \mathrm{~m}$ of transect also differed across areas, with highest numbers in the vegetated area near the road $(1.36 \pm 0.19)$ or the control area $(1.03 \pm 0.20)$ and fewer species seen in the bare area near the $\operatorname{road}(0.37 \pm 0.55, \overline{\mathrm{H}}=43.31,2$ d.f., $\mathrm{P}<0.0001)$. Number of individual 7izards seen was greatest on vegetated plots near the road $(26.4 \pm 4.2 / \mathrm{ha})$, s7ightly lower in vegetated areas well removed from the road $(18.2 \pm 3.7 / \mathrm{ha})$ and lowest in the nonvegetated areas near the road $\left(5.8 \pm 2.4 / \mathrm{ha}, F_{2.171}=\right.$ $34.8, P<0.0001)$. None of the correlations between number of 7 izards observed per species, number of species, or number of individual lizards seen per $50 \mathrm{~m}$ of transect and time of sample collection were significant (a17 probability values $>0.20$ ).

Lizard transects were walked from mid to late morning because this covers the temperature range over which the focal lizard species are active. Ground temperatures rise rapidly over this time period and can exceed lizard limits by late morning. Lack of a significant correlation between time of sample and counts within a sample (observations of number/species in a $50 \times 15 \mathrm{~m}$ section of transect) suggests that our counts did not vary across the sampling period and imply that they did not extend into inordinately high temperatures. A one way ANOVA on time of sample collection yielded similar results for the DAF timed surveys.

\section{DAF Timed Surveys}

Side-blotched lizards, whiptails, leopard Tizards, collared lizards, hornedlizards, desert spiny lizards, and zebra-tailed lizards were seen. Only three of these species were abundant enough to merit analysis. There were differences in number of lizards seen by different observers for 2 of 3 
species examined (Table 17), although differences tended to be small (Table 18). Post hoc Tukey tests could detect no differences between investigators. There were no differences across investigators in number of species seen or total number of individual lizards seen (Tables 17, 18). Differences across locations were present for all three species (Table 17) and some of these differences were quite Targe (Table 18, Figures 13 - 15). Lizard counts for side-blotched lizards, zebra-tailed lizards, whiptails, number of species pooled, or number of lizards pooled across species (Figure 16), did not differ significantly over the two one half hour sample periods (all probability values $>0.30$ ).

\begin{tabular}{|l|c|c|c|c|}
\hline $\begin{array}{l}\text { Tabie 17. Results of analysis of variance tests examining effects of } \\
\text { investigator, or search location on number of Tizards seen per 30 minute }\end{array}$ \\
\hline Species & $\mathrm{F}$ & $\mathrm{P}$ & $\mathrm{F}$ & $\mathrm{P}$ \\
\hline Side-blotched & 2.80 & 0.038 & 7.84 & 0.0001 \\
\hline Whiptailed & 1.38 & 0.258 & 2.89 & 0.034 \\
\hline Zebra-tailed & 4.01 & 0.008 & 21.81 & 0.0001 \\
\hline No. of lizard & 1.30 & 0.287 & 1.93 & 0.124 \\
\hline No. of lizard & 1.68 & 0.172 & 2.96 & 0.031 \\
\hline
\end{tabular}




\begin{tabular}{|c|c|c|c|c|c|c|}
\hline siself & 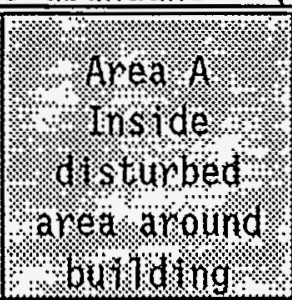 & 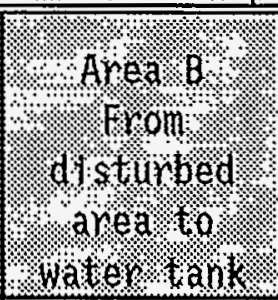 & 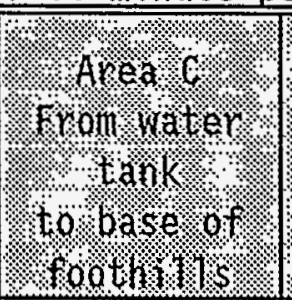 & (? & (4) & 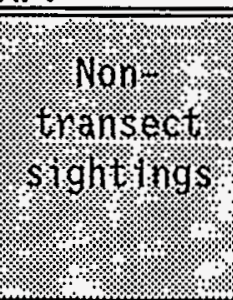 \\
\hline Gopherus agassizii & - & - & - & - & - & $B-E$ \\
\hline Callisaurus draconoides & $12.5+4.6$ & $1.7+0.9$ & $2.2+1.8$ & $2.0+1.4$ & $0.7+0.4$ & $A-C, E$ \\
\hline Crotaphytus insularis & $0.0+0.0$ & $0.0+0.0$ & $0.0+0.0$ & $0.2+0.4$ & $0.0+0.0$ & - \\
\hline Dipsosaurus dorsalis & - & - & - & - & - & - \\
\hline Gambelia wislizenii & $0.6+0.9$ & $0.1 \pm 0.2$ & $0.1 \pm 0.2$ & $0.1 \pm 0.2$ & $0.2 \pm 0.3$ & A, B, E \\
\hline Phrunosoma platyrhinos & $0.1+0.2$ & $0.1+0.2$ & $0.0 \pm 0.0$ & $0.1+0.2$ & $0.1+0.2$ & B. E \\
\hline Sauromalus obesus & - & - & -- & -- & - & D \\
\hline Sceloporus graciosus & - & -- & -- & - & - & - \\
\hline Sceloporus magister & $0.2+0.3$ & $2.0 \pm 1.1$ & $1.3 \pm 1.0$ & $0.7 \pm 1.0$ & $2.0+0.6$ & $B-E$ \\
\hline Sceloporus occidentalis & - & - & - & - & -- & - \\
\hline Uta stansburiana & $0.7+0.5$ & $7.4+3.0$ & $5.9+2.4$ & $6.9+1.8$ & $4.2+1.7$ & $A-E$ \\
\hline Coleonyx variegatus & - & - & - & - & - & $E$ \\
\hline Xantusia vigilis & - & - & - & - & $\ldots$ & - \\
\hline Cnemidophorus tigris & $1.1+0.6$ & $2.7+1.7$ & $0.8+0.5$ & $0.9+0.6$ & $1.2+0.7$ & $A-E$ \\
\hline Eumeces gilberti & - & $\ldots$ & -- & $\ldots$ & - & - \\
\hline Eumeces skiltonianus & - & - & - & - & -- & - \\
\hline No. lizard species & $2.8+0.7$ & $3.7+0.4$ & $3.3+0.3$ & $3.1+0.6$ & $3.5+0.5$ & $\ldots$ \\
\hline
\end{tabular}




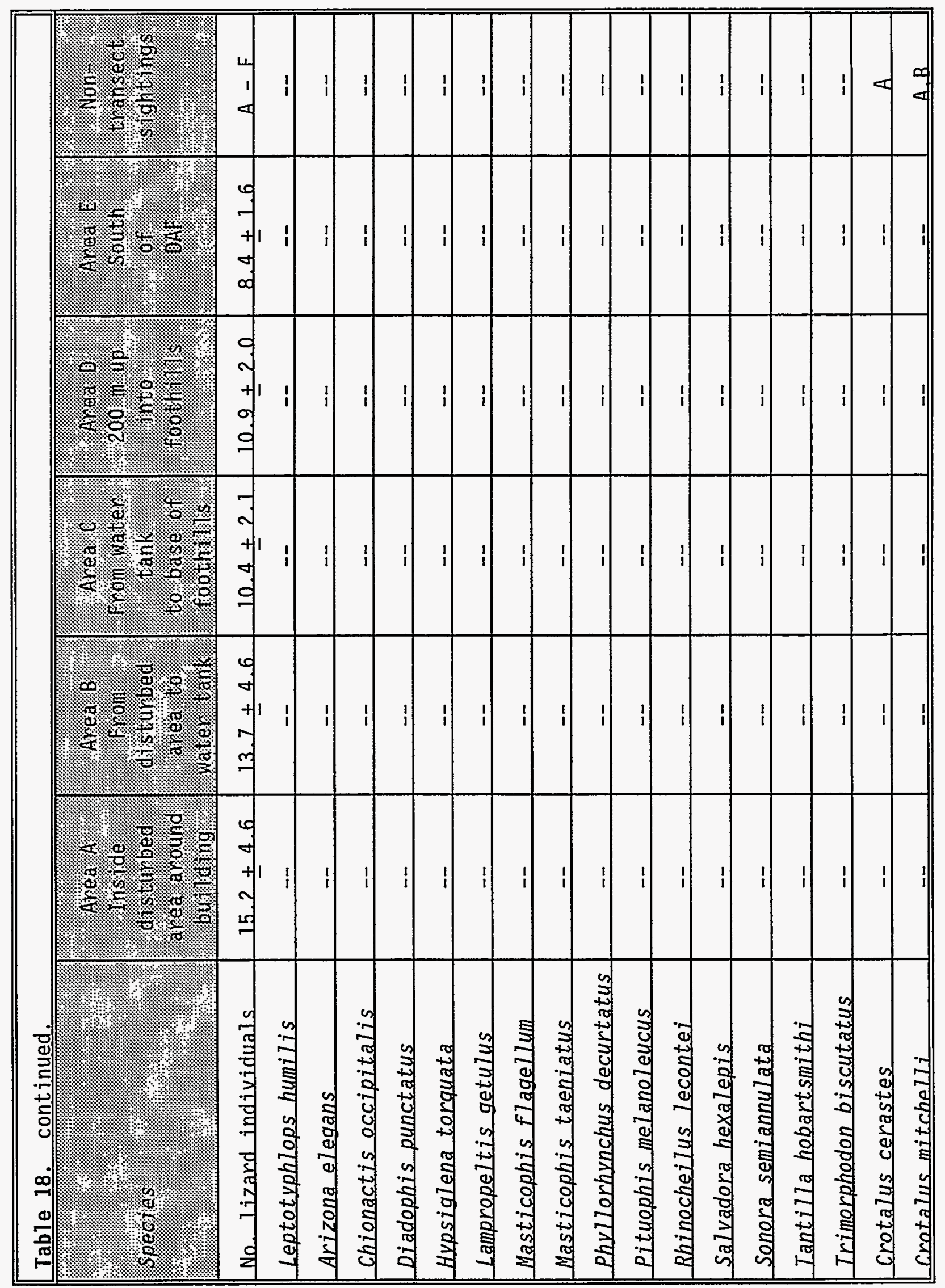




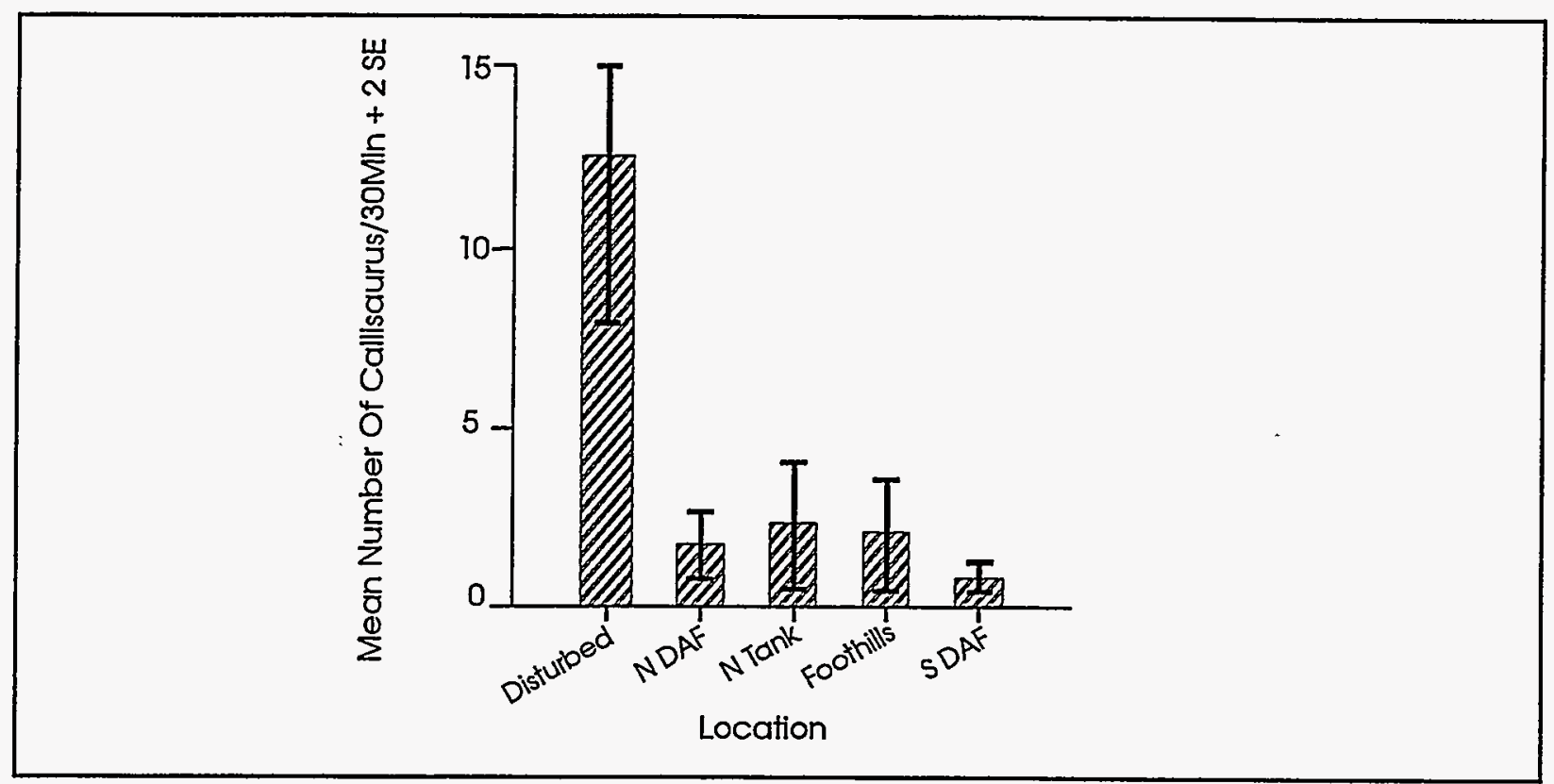

Figure 13 - Mean number of zebra-tailed lizards seen per 30 minute search in five areas near the DAF in summer 1993.

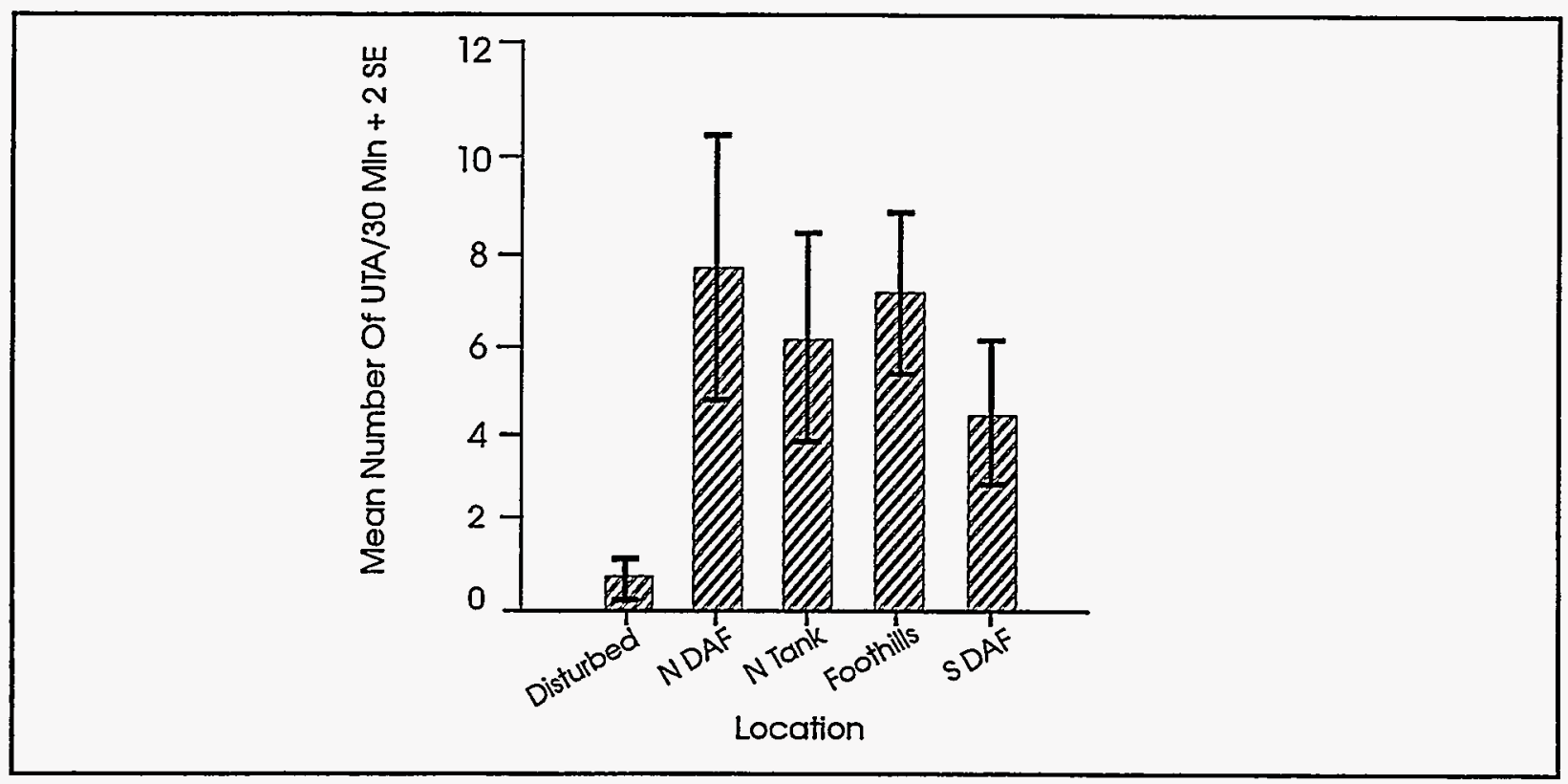

Figure 14 - Mean number of side-blotched Tizards seen per 30 minute search in five areas near the DAF in summer 1993. 


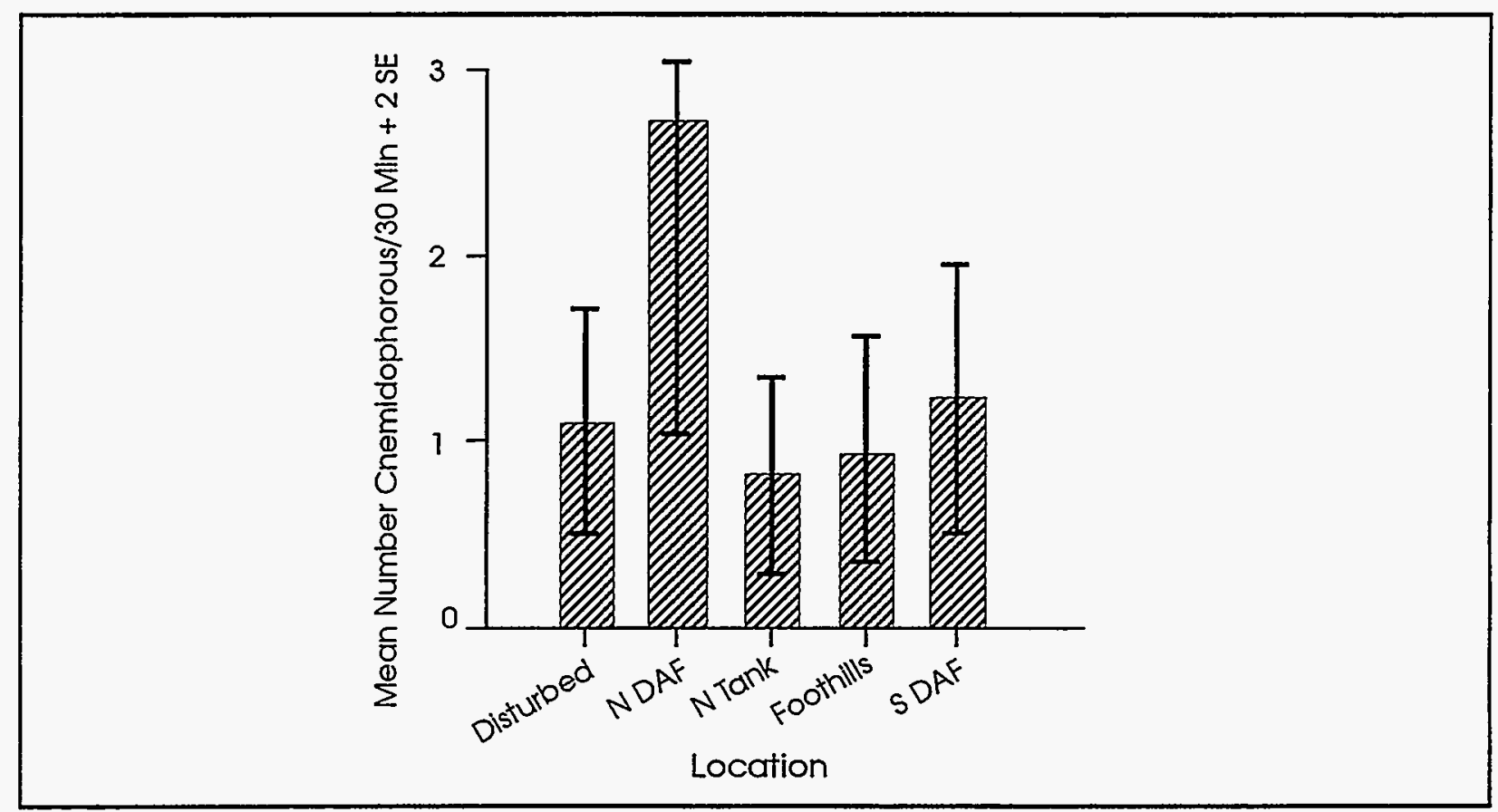

Figure 15 - Mean number of whiptail lizards seen per 30 minute search in five areas near the DAF in summer 1993.

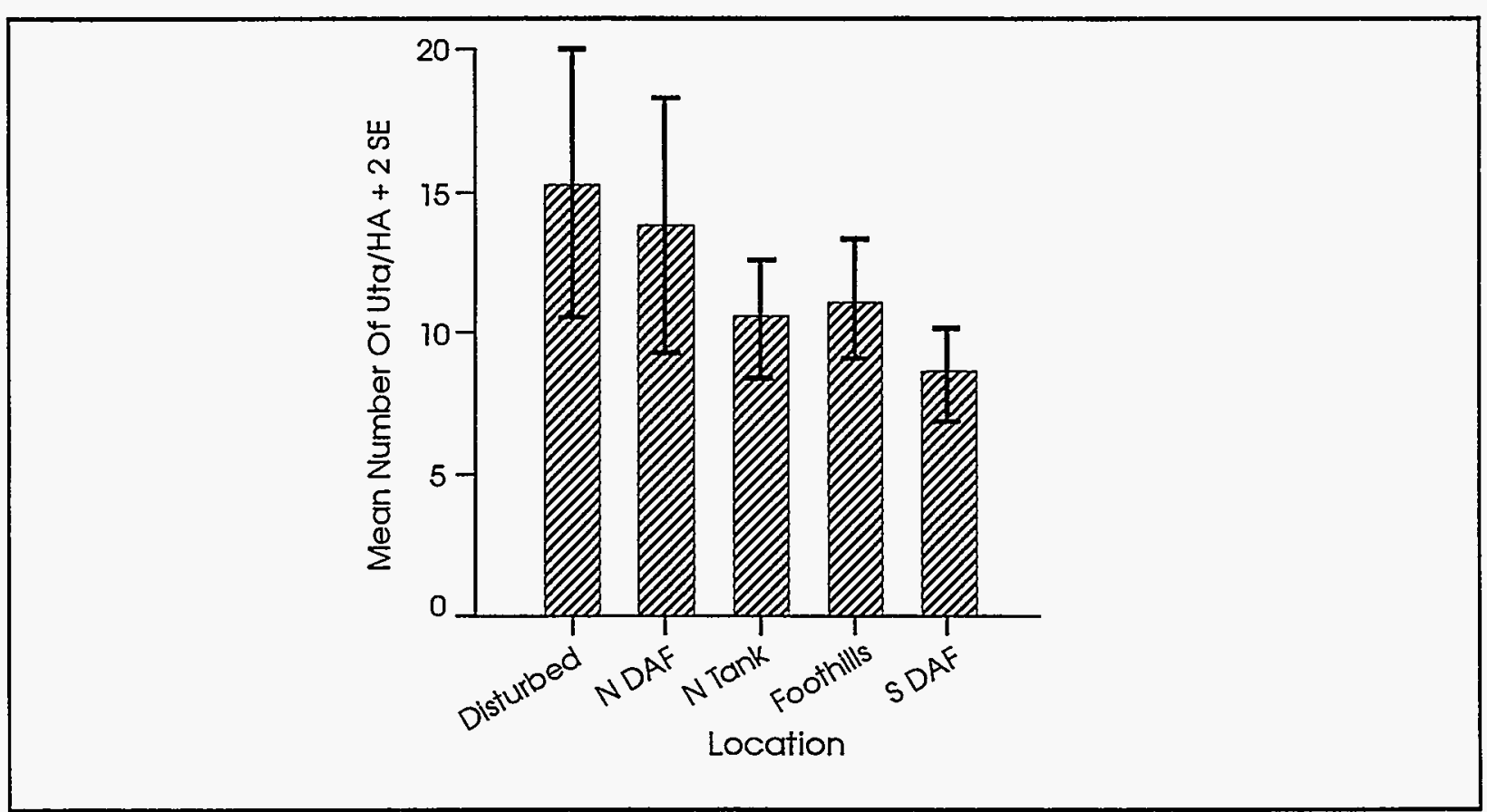

Figure 16 - Mean number of lizards (pooled across 277 species) seen per 30 minute search in five areas near the DAF in summer 1993. 


\section{Reptile Species}

Many reptile species were seen near the DAF (Table 18). The species list for lizards is relatively complete, whereas many snakes that are likely living there were not seen. Most species were widely distributed (Table 18), however, chuckwallas and collared lizards appear to be restricted to the rocky hillsides. One banded gecko (Coleonyx variegatus) was seen in an undisturbed area south of the DAF buildings. These lizards are not commonly seen, which may be a consequence of their secretive nature, and not a reflection of their relative scarcity. Several man-hours were put into rolling approximately 500 fallen Yucca trunks in an attempt to find the night Tizard (Xantusia vigilis); none were seen.

Several man hours were spent looking for chuckwallas (Sauroma7us obesus) in the foothil7s to the $N$ and $W$ of the DAF as the State of Nevada is becoming increasingly concerned over chuckwalla populations. One chuckwalla was seen in the foothills east of Mercury highway, approximately $4 \mathrm{~km}$ from the DAF buildings. Chuckwalla scat (of unknown age) was seen in several locations in the foothills north and west of the DAF buildings. Chuckwallas probably still occupy the surrounding foothills. Desert tortoises (Gopherus agassizii) or their remains were seen in a71 areas near the DAF except the disturbed DAF area. One Tive tortoise was marked and measured on 5 May 1993 approximately $300 \mathrm{~m} \mathrm{NW}$ of the DAF ditch, and captured and measured again on 15 September approximately $100 \mathrm{~m}$ east of the DAF buildings on the paved access road. It had grown two $\mathrm{mm}$ in plastron length. A77 other sightings consisted of old tortoise remains (she17s or scutes) and were concentrated to the north and west of the DAF buildings, however some were also present south of these buildings. Desert tortoise (federally threatened) and chuckwalla (state species of special concern and a federal candidate-category-2-species) were the only reptiles of special concern observed in the vicinity of the DAF.

\section{BIRDS}

\section{Sewage Pond vs Natural Area}

Bird usage of the DAF sewage ponds during spring (March-Apri1) was Tow followed by heavy summer use. The three most abundant species observed during 1993 were mourning doves, house finches and black-throated sparrows. Usage varied significantly between the above three species during spring-summer 
$\left(F_{2.20}=61.0, P<0.0001\right)$ but not across individual dates $\left(F_{10.20}=0.75, P=\right.$ 0.67 , Table 19).

Mean air temperature $\left({ }^{\circ} \mathrm{C}\right)$ at the pond $(28.5 \pm 2.0)$ did not differ from that in the natural habitat $(29.3 \pm 2.3)$ even though they were often sampled one hour apart $(t=0.88,12$ d.f., $P=0.40)$. Numbers of birds on the natural habitat area were quite low (Table 19). There were no differences in total number of the dominant three species counted across dates in spring-summer $\left(F_{10.20}=1.3\right.$, $P=0.30)$. However, counts of al1 three species differed from each other on the natural plot during spring-summer $\left(F_{2.20}=21.8, P<0.0001\right.$; Tukey tests $)$.

Mourning doves (Zenaida macroura) and house finches (Carpodacas mexicanus) arrived in high numbers in early May (Table 19). Counts (bird visits/hr) from outside the vehicle during two weeks from April 28-5 May $(n=4)$, averaged 69 \pm 34 for doves (range $=30-100$ ) and $51 \pm 36$ for house finches (range 20-97). On 5 May 1993, dove counts from outside and inside the vehicle were compared: 97 verses 233 respectively: a large observer effect.

A second modification involved searching a natural habitat area (Plot 1 ) on foot $(n=8)$ versus making counts from a fixed position $(n=3)$. There appeared to be no difference between techniques in terms of birds observed per unit time $(t=0.6,9$ d.f. $P=0.56)$.

Mean dove use of the pond was greater than house finches and black-throated sparrows (Tukey test, $P=0.0001$ for both comparisons) during the summer, reaching a peak in early June (Table 19). Doves declined gradually through July and were absent by September. House finches were numerous at the ponds but only from May-June. Finch numbers dropped to near zero by the middle of July but returned in moderate numbers by fal1. The coefficient of variation for finches was highest (160\%) for a11 species during the summer. Average use by house finches and black-throated sparrows did not differ (Tukey test, $P=$ 0.99 ), although they used the pond at different times of the year (Table 19).

Doves used the sewage pond more than a natural habitat on all dates $(n=10)$ during spring-summer (Table 20, Figures 17, 18). House finches also used the pond at significantiy greater rates than a control during mid-May through midJune and again in the fall for one date (Table 20, Figures 19, 20). In May through June, black-throated sparrows used the control location in greater numbers than the sewage pond (Table 20). This species did not use the ponds until the end of June when mid-morning temperatures exceeded $25{ }^{\circ} \mathrm{C}$. Juveniles 
comprised almost all of the sightings of black-throated sparrows seen in JuTy (Table 19). Pond use was greater throughout July than natural habitat use (Table 20, Figures 21, 22).

Table 19. Total number of bird visits per hour of the dominant species at the DAF sewage pond and an undisturbed location during spring-fall of 1993. Mean \pm 2 se and coefficient of variation $\%$, = SD/Mean $\times 100$ for summer, $N=$ 11. Dashes $=$ not sampled.

\begin{tabular}{||c|c|c|c|c|c|c||}
\hline & $\begin{array}{c}\text { House } \\
\text { finches }\end{array}$ & $\begin{array}{c}\text { Mourning } \\
\text { doves }\end{array}$ & $\begin{array}{c}\text { Black- } \\
\text { throated } \\
\text { sparrows }\end{array}$ & $\begin{array}{c}\text { House } \\
\text { finches }\end{array}$ & $\begin{array}{c}\text { Mourning } \\
\text { doves }\end{array}$ & $\begin{array}{c}\text { Black- } \\
\text { throated } \\
\text { sparrows }\end{array}$ \\
\hline $3-10-93$ & 0 & 0 & 0 & - & - & - \\
\hline $3-24-93$ & 0 & 0 & 0 & - & - & - \\
\hline $5-13-93$ & 121 & 356 & 0 & 0 & 1 & 5 \\
\hline $5-18-93$ & 145 & 390 & 0 & 3 & 4 & 18 \\
\hline $6-03-93$ & 100 & 622 & 0 & 2 & 7 & 13 \\
\hline $6-17-93$ & 19 & 492 & 0 & 0 & 6 & 11 \\
\hline $6-29-93$ & 2 & 407 & 22 & 0 & 5 & 14 \\
\hline $7-08-93$ & 1 & 343 & 63 & 0 & 5 & 6 \\
\hline $7-14-93$ & 2 & 324 & 53 & 0 & 5 & 0 \\
\hline $7-15-93$ & 0 & 375 & 66 & 0 & 4 & 10 \\
\hline $7-20-93$ & 0 & 222 & 65 & 0 & 6 & 3 \\
\hline $7-22-93$ & 0 & 241 & 62 & 0 & 5 & 9 \\
\hline $7-27-93$ & 0 & 267 & 112 & 0 & 2 & 14 \\
\hline $9-30-93$ & 26 & 0 & 0 & - & - & - \\
\hline $10-19-93$ & 4 & 0 & 0 & 0 & 0 & 0 \\
\hline $11-02-93$ & 7 & 0 & 0 & 0 & 0 & 0 \\
\hline $11-10-93$ & 26 & 0 & 0 & 0 & 0 & 0 \\
\hline Mean+2se & $35+34$ & $367+70$ & $40+22$ & $0.45+1.0$ & $4.5+1.0$ & $9.4+3.2$ \\
\hline Coeff Var & 160 & 31 & 94 & 228 & 39 & 58 \\
\hline \hline
\end{tabular}

${ }^{\text {a }}$ calculated for May-July onTy: Control not sampled on 30 September. 
Table 20. Comparisons of bird counts (number $/ 5$ minutes) between sewage pond and control at DAF for various dates. $P$ values in parentheses. $T$ values in light print (22 d.f.); $H$ values for Kruskal-Wallis test ( 1 d.f.) in bold; used for cases where species was absent on one plot. * = species absent from both habitats. NS = not significant. NC = no comparison because sample sizes were too small.

\begin{tabular}{|c|c|c|c|c|}
\hline 1010.1. & Touru & 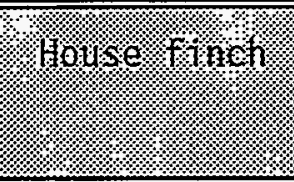 & : & 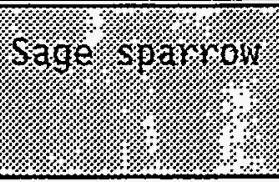 \\
\hline $5-18-93$ & $3.2(.008)$ & $3.9(.002)$ & $15.2(.0001)$ & * \\
\hline $6-03-93$ & $9.7(.00001)$ & $5.7(.0001)$ & NC & * \\
\hline $6-17-93$ & $14.2(.00001)$ & $9.1(.003)$ & $7.5(.006)$ & * \\
\hline $6-29-93$ & $4.9(.0005)$ & $1.0(.32) \mathrm{NS}$ & $\mathrm{NC}$ & * \\
\hline $7-08-93$ & $6.6(.00001)$ & $1.0(.32) \mathrm{NS}$ & $3.5(.0046)$ & * \\
\hline $7-14-93$ & $9.4(.00001)$ & NC & $15.0(.0001)$ & * \\
\hline $7-15-93$ & $5.4(.0002)$ & $\star$ & $3.2(.0066)$ & $*$ \\
\hline $7-20-93$ & $3.8(.0029)$ & * & $3.0(.011)$ & * \\
\hline $7-22-93$ & $3.4(.0058)$ & * & $2.1(.053)$ & * \\
\hline $7-27-93$ & $6.1(.0001)$ & * & $3.1(.0074)$ & * \\
\hline $10-19-93$ & $*$ & $2.1(.15) \mathrm{NS}$ & * & $0.3(.79)$ NS \\
\hline $11-02-93$ & $*$ & $3.3(.07) \mathrm{NS}$ & * & $11.0(.001)$ \\
\hline $11-10-93$ & * & $4.6(.033)$ & * & $9.1(.003)$ \\
\hline
\end{tabular}

Sage sparrows (Amphispiza bel7i) were first observed at the DAF area in October. They used both pond and natural habitats equally at this time. However, in November, pond use exceeded use of the natural area (Table 20, Figures 23, 24). Sage sparrows usually breed at higher elevations in the northern part of the NTS, and are common migrants through Frenchman flat in winter (Hayward et a7. 1963). Other sparrow usage was minimal and included white-crowned sparrows (fal1), Brewer's sparrows (spring and fall) and song sparrows (spring). 


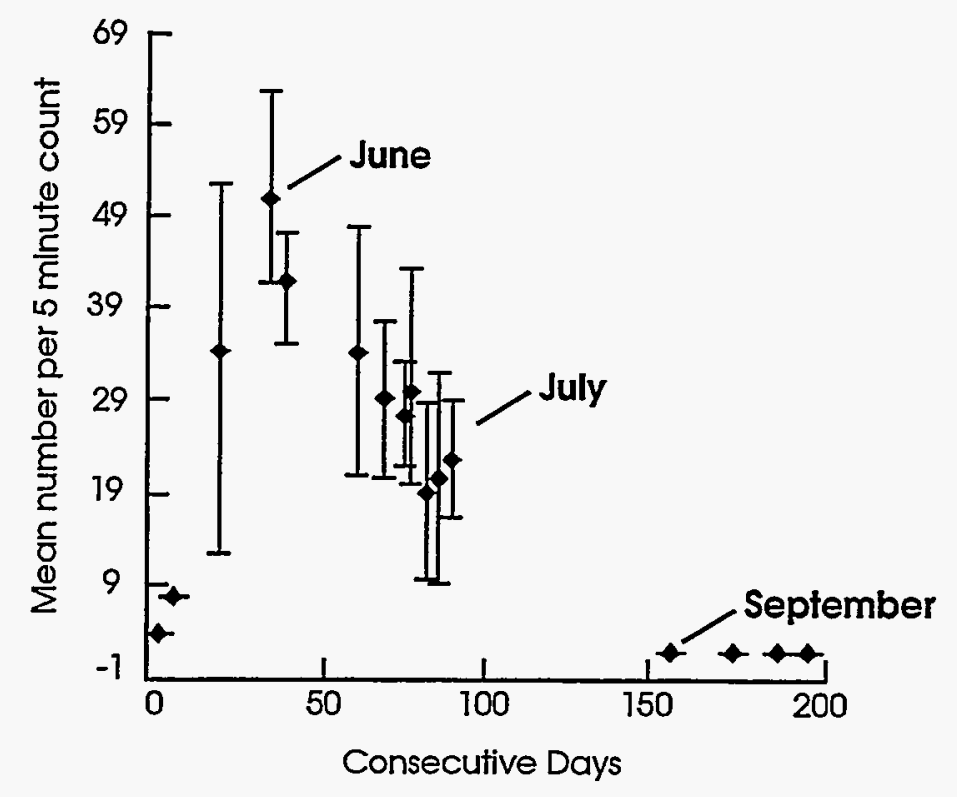

Figure 17 - Sewage pond use by mourning doves.

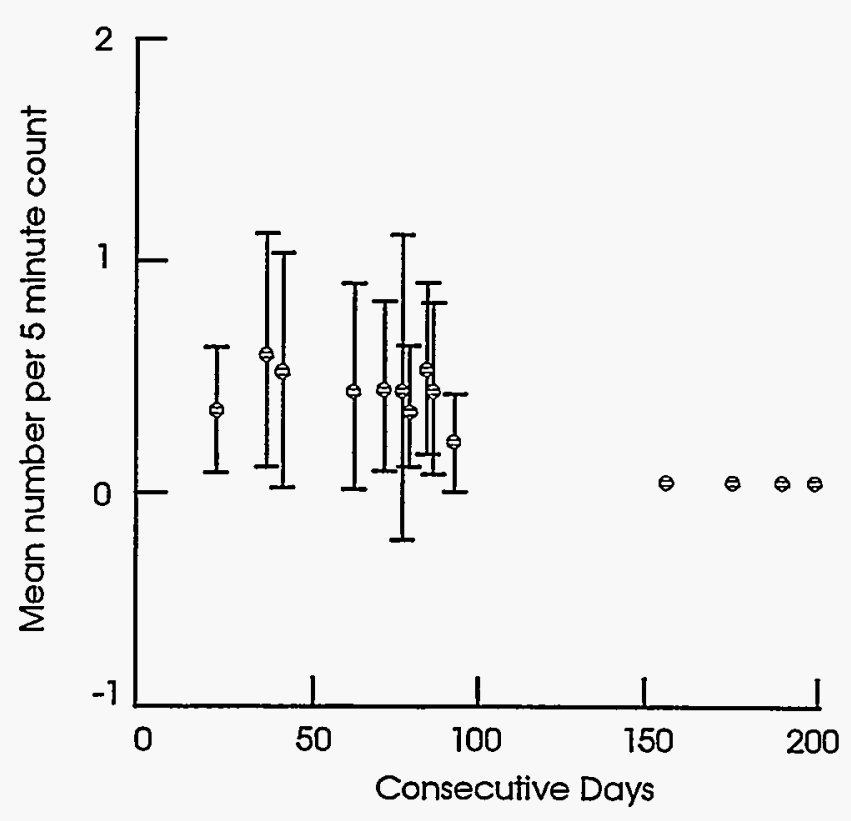

Figure 18 - Natural habitat use by mourning doves. 


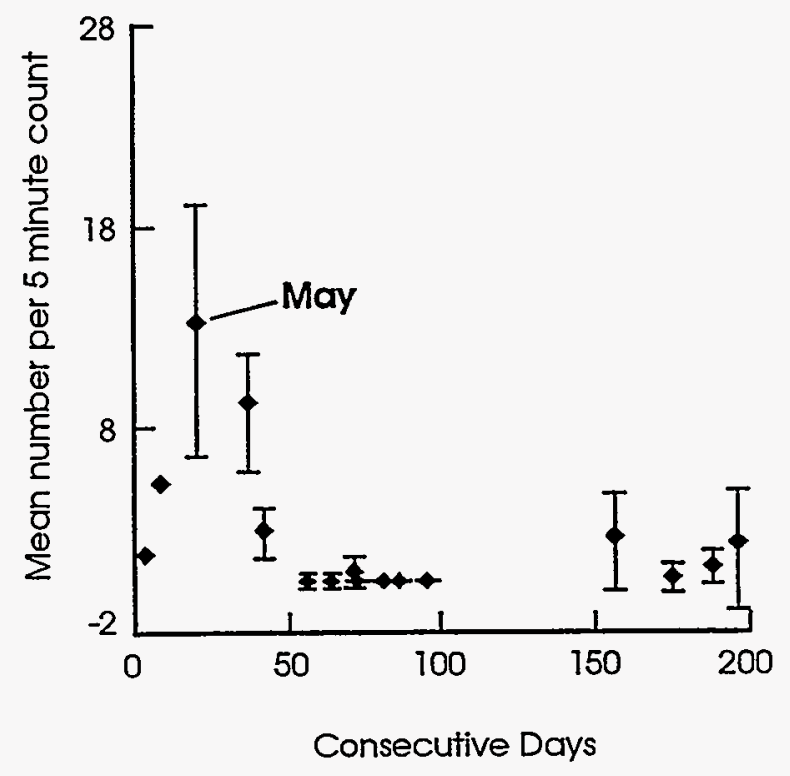

Figure 19 - Sewage pond use by house finches.

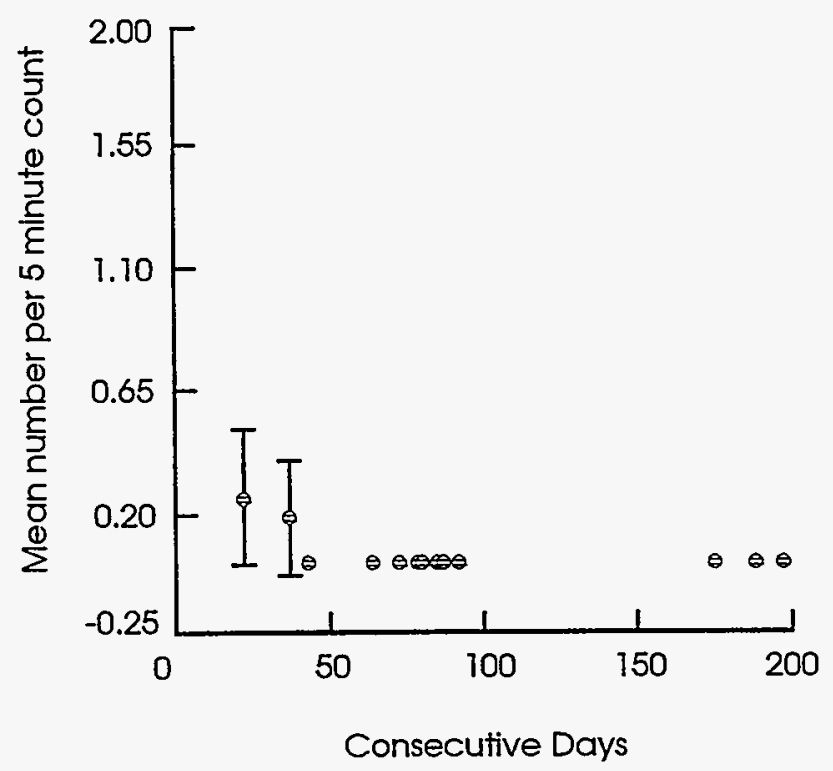

Figure 20 - Natural habitat use by house finches. 


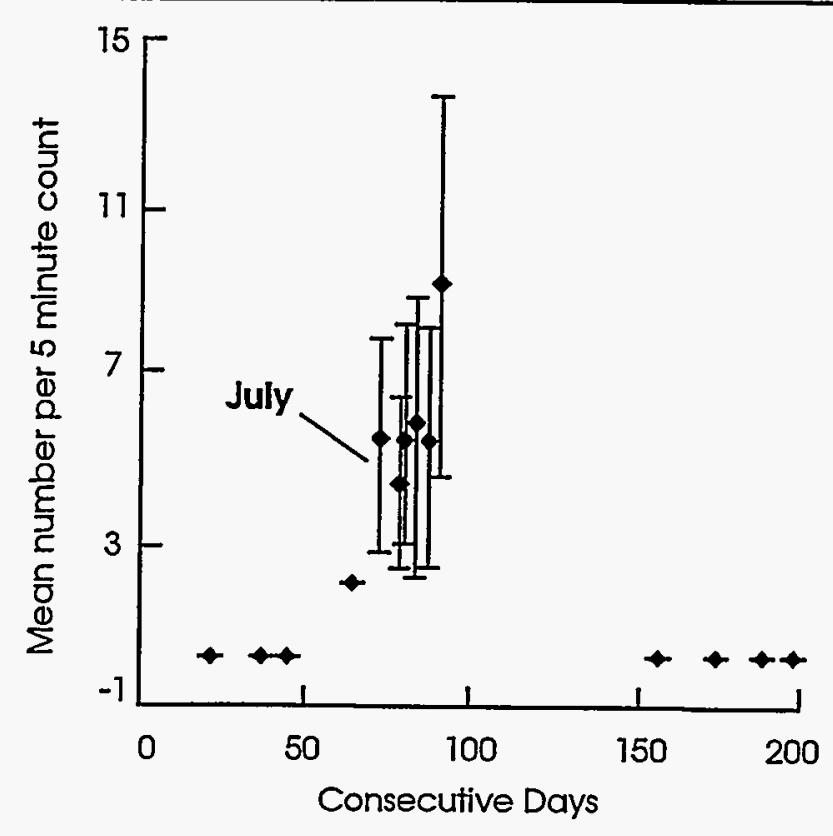

Figure 21 - Sewage pond use by black-throated sparrows.

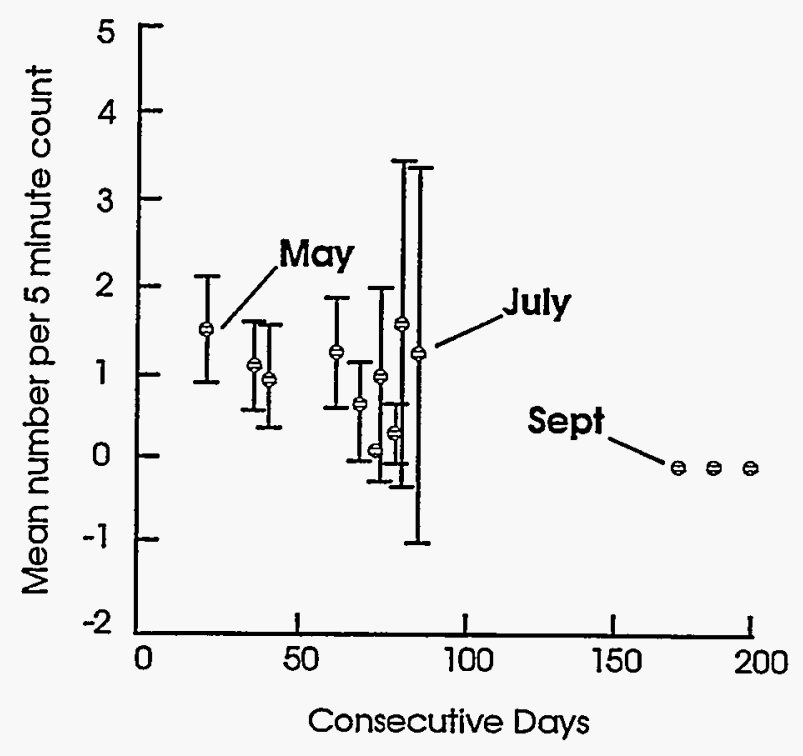

Figure 22 - Natural habitat use by black-throated sparrows. 


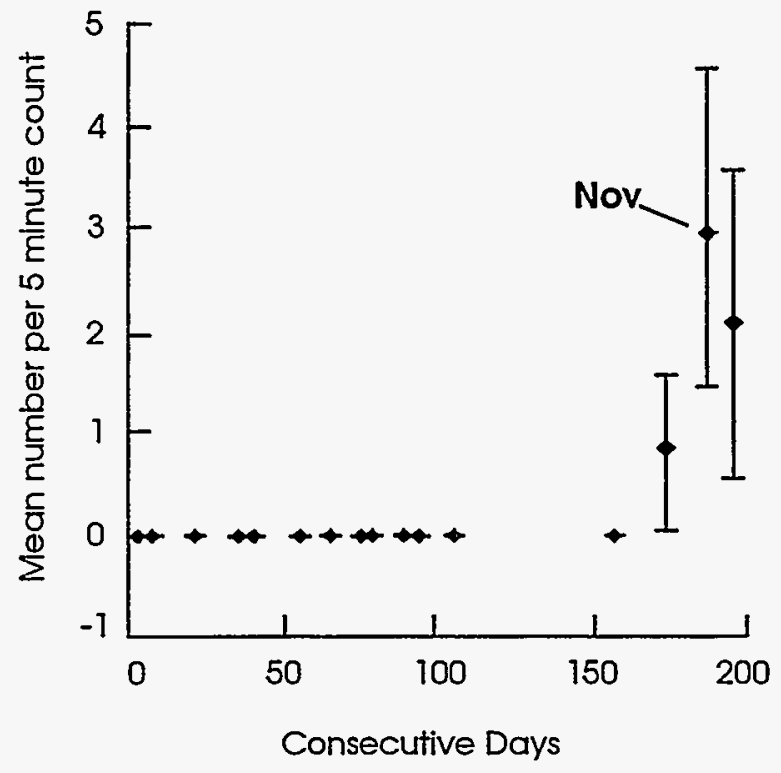

Figure 23 - Sewage pond use by sage sparrows.

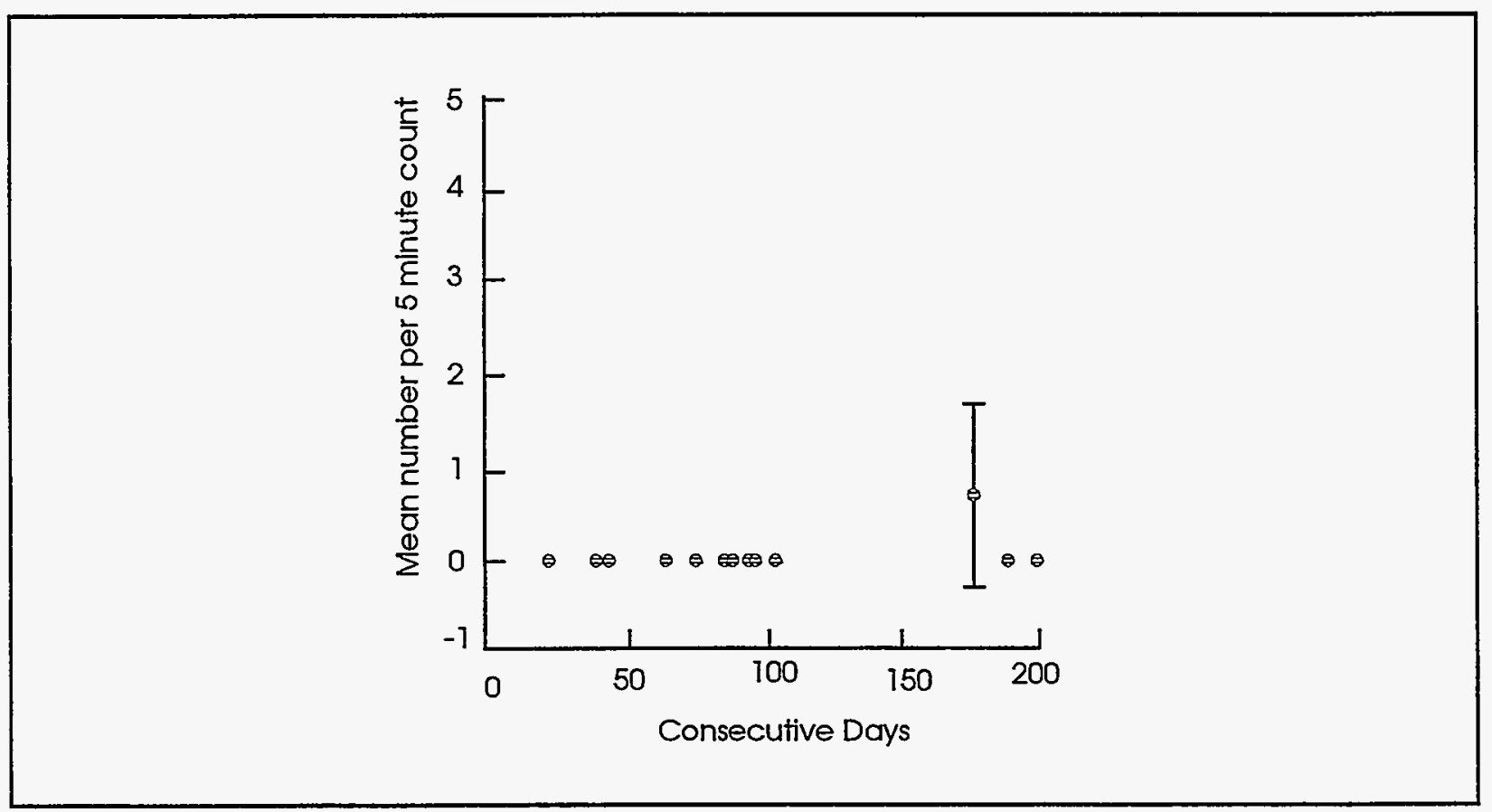

Figure 24 - Natural habitat use by sage sparrows. 
Other Migrant Use

During 1993, 39 species (25 were passerine species or perching birds) used the sewage ponds for resting, drinking or foraging (Appendix D). Thirteen of these were seen in natural habitats. Eleven species of shorebirds and ducks were seen at the sewage ponds but not in other habitats. These included spotted sandpiper, least and western sandpiper, American avocet, willet, snowy egret, bufflehead, and cinnamon and green-winged teal. Raptors observed were prairie falcon, red-tailed hawk and barn owl. Prairie falcons hunted doves and one was observed making a kill during mid-day. A red-tailed hawk was sighted drinking from the pond in mid July. Barn owls were also seen in one evening visit at the pond during JuTy. Throughout the summer, remains of doves and regurgitated food pellets commonly littered the sewage pond area, suggesting heavy bird predation.

Species seen at sewage pond, roads, and buildings included common raven, American pipit, horned lark, barn owl, starling, and European house sparrow. Several barn owls (on two occasions) and an American kestrel were removed from inside the DAF building during August. Two barn owls died near the DAF building in July and August.

\section{Ravens}

Ravens were not abundant at the sewage pond. They were seen on on $7 y 55 \%$ of visits throughout the year with an average sighting rate of $1.25 \pm 0.7$ ravens per hour. Numbers sighted increased in fall (Figure 25) over spring and summer $\left(F_{2,17}=18.4, P<0.0001\right)$ although totals were low. In addition, moderate numbers of ravens $(4,4,1)$ were observed on plot 1 ( 3 one hour visits, respectively) in October-November while very few (2 total) were observed during the spring-summer ( $n=16$ visits, $>20 \mathrm{hrs}$ of observation) in natural habitats north of the DAF building. Therefore, raven numbers sighted from the control area appear consistent with numbers at the sewage pond with in each season. Maximum number of ravens observed at the pond during a visit was twe 7 ve on 10 November. Most birds arrived in singular fashion over a 10-15 minute period as though they were being recruited by presence of other birds. 


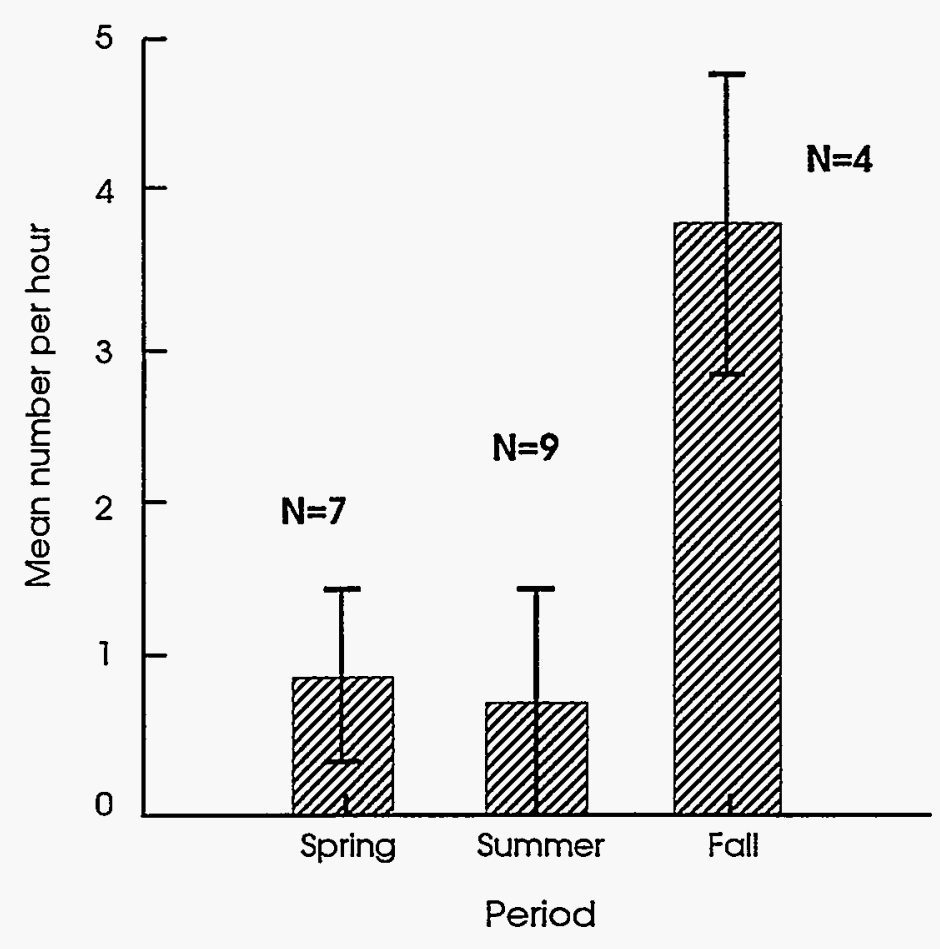

Figure 25 - Ravens observed at the DAF sewage pond 1993, $\mathrm{N}=$ number of visits.

\section{Bird Species on Undisturbed Habitats}

We observed 31 bird species in natural habitats near the DAF in 1993.

Eighteen of these were not seen at the sewage ponds. Raptors sighted were American kestrel, osprey, golden eagle, red-tailed hawk, and Swainson's hawk. Non-breeders in natural habitats included cactus wren, ladder-backed woodpecker, black-headed grosbeak, sage thrasher, mountain bluebird, pinyon jay and long-billed curlew. Breeding species detected at the DAF in 1993 were black-throated sparrow, mourning dove, house finch, northern mockingbird, Scott's oriole, and burrowing owl. Other probable breeders in the DAF vicinity as evidenced by the presence of juveniles during June-July were chukar, ash-throated flycatcher, Say's phoebe, loggerhead shrike, and western kingbird. Supplemental information of nesting is shown in Table 21.

Breeding activity for birds in the DAF region peaked in mid-May. Breeding periods for species were as follows: black-throated sparrow, early May to early June; house finch, late April to mid-May; mourning dove, early May to early July; northern mockingbird, early May to late May. 


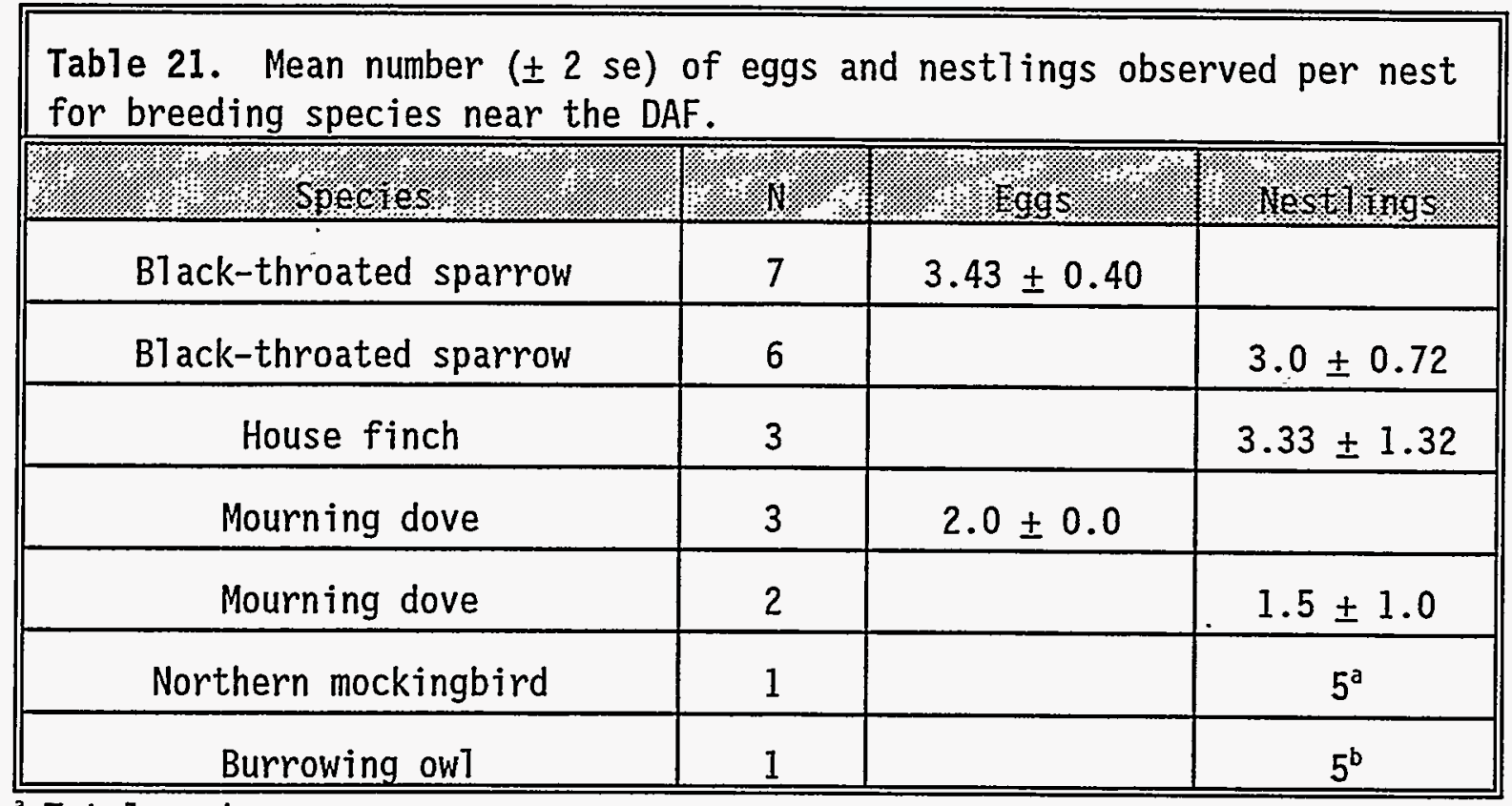

$\stackrel{a}{=}$ Total number

$b=$ Total number of fledg7 ings observed at one burrow.

In the area north of the DAF building (Fig. 1), densities of black-throated sparrows did not vary significantly with respect to plot location $\left(F_{4.12}=1.6\right.$, $P=0.25)$ or sampling date $\left(F_{3.12}=1.2, P=0.36\right)$. Furthermore, blackthroated sparrow numbers did not differ across al1 plots, $\left(F_{6.19}=1.2, P=\right.$ 0.33). In natural areas (Plots 1-7) there were no changes in black-throated sparrow numbers from late Apri1 through June $\left(F_{5.19}=2.2, P=0.10\right)$. Combining all plots sampled $(n=7)$, and using a radius of detectability of 60 $\mathrm{m}$, density of $\mathrm{black}$-throated sparrows was about $1.87 \pm 0.46$ birds/ha (187 birds $/ \mathrm{km}^{2}$ ). Mean number of black-throated sparrows estimated per ha was significantly greater than 0 for all plots $(t=8.13,25$ d.f., $P<0.001)$.

Northern mockingbird density was estimated at about $0.09 \pm 0.04$ birds/hectare ( 9 birds $/ \mathrm{km}^{2}$ ) with a radius of detectability of $150 \mathrm{~m}$. Because of low numbers, densities of other species present could not be estimated.

\section{Sensitive Bird Species}

Sensitive bird species that have recently been observed on Frenchman Flat include the American peregrine falcon, white-faced ibis, and loggerhead shrike. Peregrine falcons are uncommon to rare migrants in this region, but 
could occur at the DAF. One was sighted in 1992 on north Frenchman Flat near a we11 pond: the first NTS record since 1976.

White-faced ibis are common migrants through the NTS region and are regulariy sighted at we11 reservoirs throughout the NTS during spring and fall but are not abundant. This species will probably use the DAF sewage pond for short resting and foraging stops.

Loggerhead shrikes are common summer residents on the NTS and appear to breed near the DAF. They have been observed around the DAF regularly in summer, and may use the fence around the DAF compound for perching and impaling lizards.

It is possible that bald eagles may rarely migrate onto the NTS. Several sightings of bald eagles were made near Rock Valley in 1977 (Castetter and Hil1 1979). At present, a smal1 population of bald eagles winters at Pahranagat Lake National Wildl ife Refuge, less than $100 \mathrm{~km}$ northeast of the NTS. Additional sensitive bird species that have been observed recently on the NTS include Swainson's hawk, with several sightings on Frenchman Flat and at the DAF and northern goshawk (Rainier Mesa). There are no other sensitive bird species expected in the vicinity of the DAF facility.

\section{MAMMALS}

\section{Rodents Present}

Several smal1 mammal species were captured at each site during 1993 (Table 22). The three sites differed in onty three species: Perognathus 7ongimembris, Peromyscus maniculatus, and Ammospermophi7us leucurus. $P$. maniculatus was captured in low numbers only on the roadside 7 ine and inside the building, while $P$. Tongimembris and $A$. leucurus (antelope ground squirre7s), were not captured on the line north of the facility (FRF011). There were no species unique to line FRFO1l or the building.

\begin{tabular}{|c|c|c|c|c|}
\hline Spectes & $\sqrt{218} 6008$ & 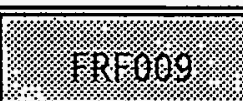 & 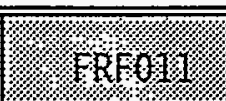 & 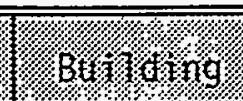 \\
\hline Chaetodipus formosus & * & * & * & * \\
\hline Dioodomys merriami & $*$ & $*$ & * & \\
\hline
\end{tabular}




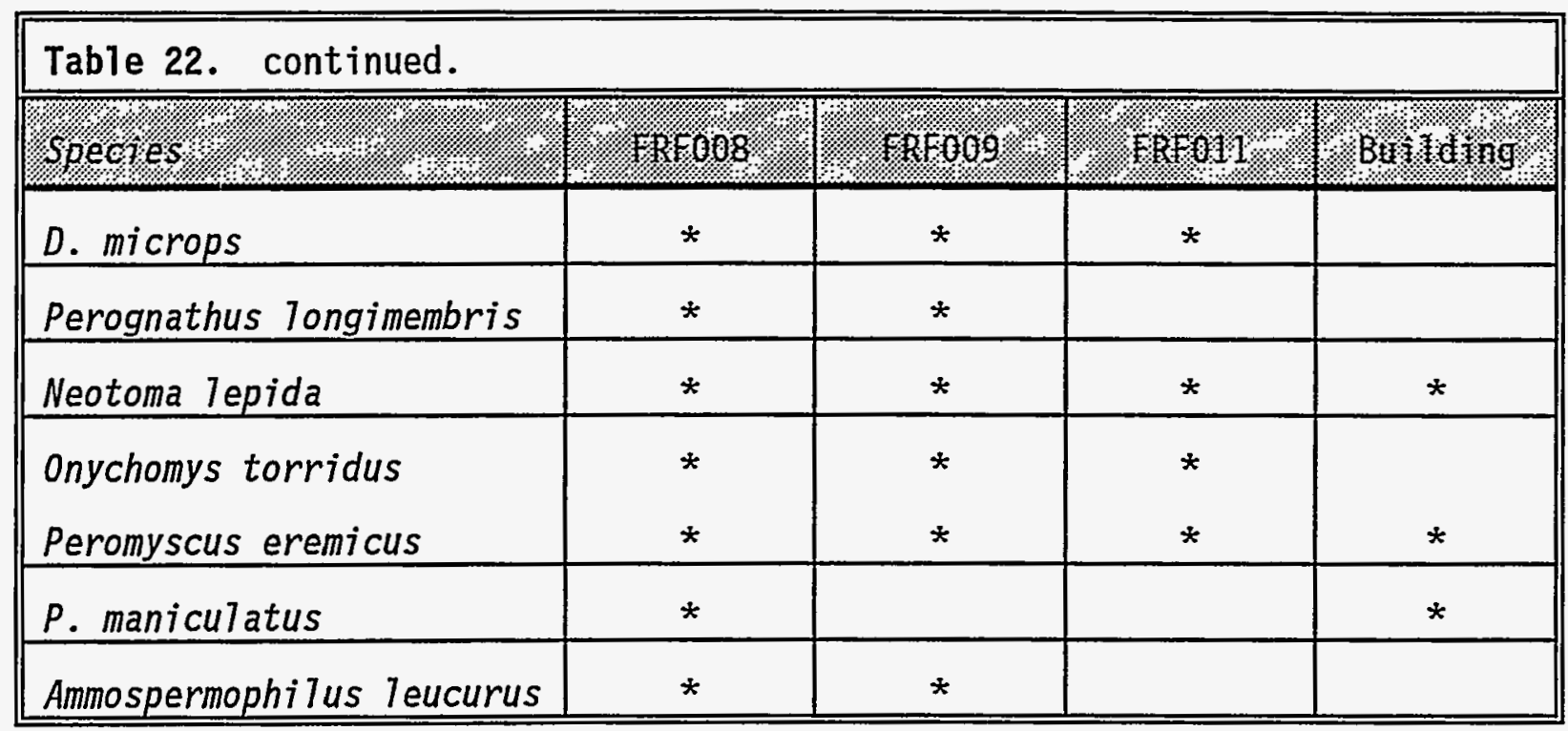

\section{Other Mammal Species}

In addition to rodents, coyotes (Canis Tatrans) were observed at the sewage lagoon and raided mesh traps on FRF008 and FRF009. Jackrabbits (Lepus californicus) were observed at a 17 three locations. Coyotes reproduced in the vicinity of the sewage ponds. A lactating female was observed drinking at the sewage ponds on several occasions and several juveniles were also observed. Coyotes were seen on about $35 \%$ of visits and sighting rates were 10 w $0.4 \pm$ 0.3 /hour, $n=20)$. One dead juvenile coyote was found at the sewage pond.

Two Jackrabbits drank from the sewage pond on 22 JuTy. Deer tracks were observed around the perimeter of the sewage pond in June, although they did not appear to enter the fenced area. Pronghorn antelope were reported on several occasions from west Frenchman flat in 1993, and are possible visitors to the area.

Jackrabbits were observed on natural habitats at an average sighting rate of $0.65 \pm 0.30$ rabbits/hour $(N=40)$, with 120 hours of effort. This frequency changed with season. More jackrabbits were seen in JuTy per observer effort $\left(F_{5.34}=4.5, P=0.003\right.$ ) than in March, April and May (Figure 26). Deer tracks and accompanying mountain lion tracks were observed on trails in the foothills west of DAF during two dates in mid-summer. 


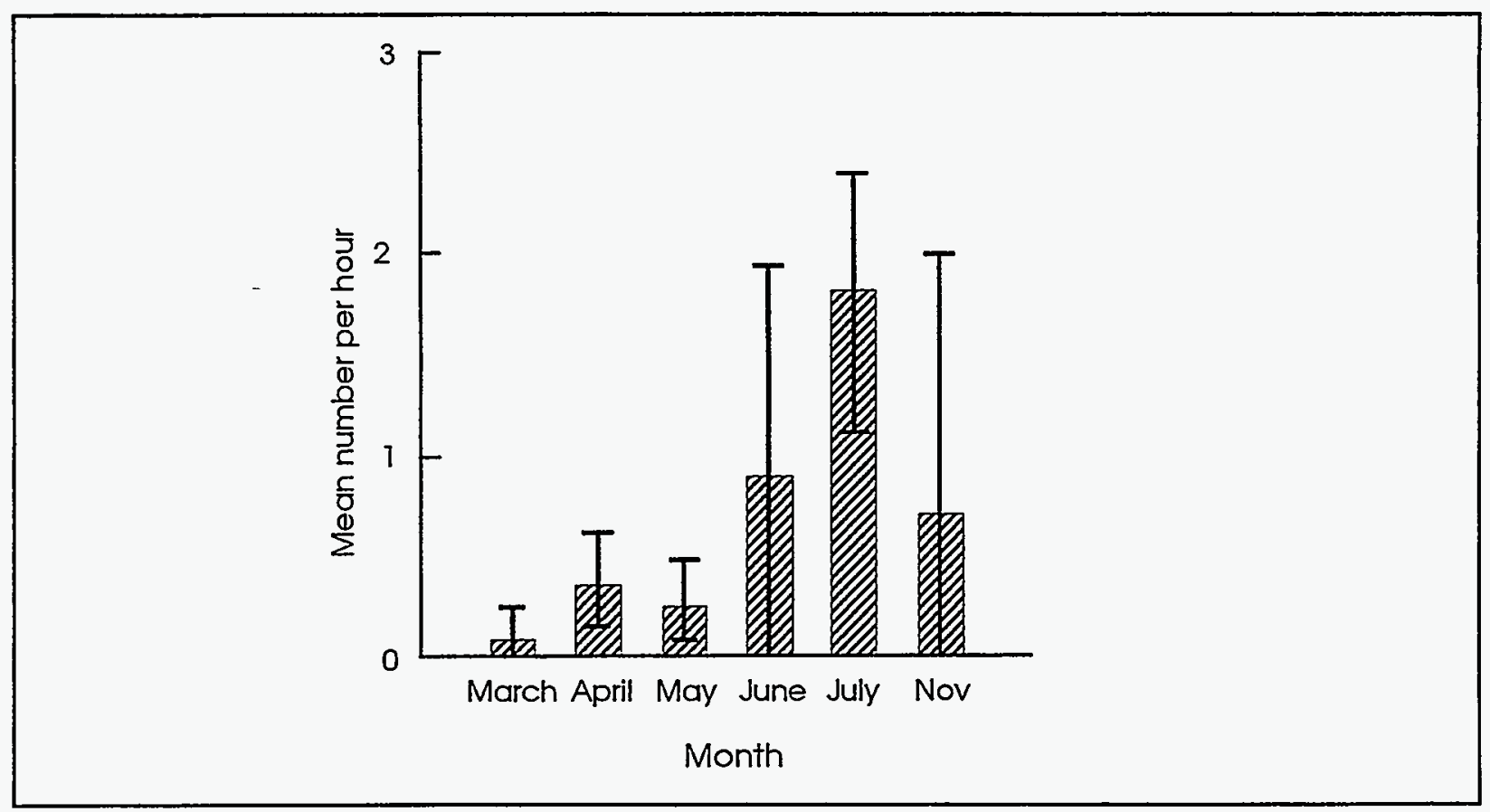

Figure 26 - Mean number of jackrabbits observed in natural habitats at the DAF.

\section{Abundance and Roadside Effects}

Small mammal trap success at all three sites in early June was high: 38.2 , 41.9 and $51.0 \%$ at 1 ines 8,9 and 11 respectively. Tripped and moved or missing traps were included in the total number of captures since it was assumed an animal had been inside the trap but was released and/or eaten by a predator.

The most abundant rodent at the two southern lines was Dipodomys merriami. This was not the case north of the DAF where Chaetodipus formosus was most common (Table 23). A twoway ANOVA revealed that plot location influenced trap success per 10-stakes $\left(F_{2.60}=8.73, P=0.00047\right)$ but that trap type did not $\left(F_{1.60}=2.68, P=0.107\right)$. There was also no interaction between the two terms $\left(F_{2.60}=0.74, P=0.481\right)$. The greater abundance at FRF011 might be attributed to the vegetation and topographic difference: 11 had more Joshua trees and washes while 8 and 9 were quite similar in plant type.

While not significant, two 10 -stake sections on FRF008 with the lowest average captures $(5.3 \pm 0.6$ and $6.3 \pm 2.1)$ coincided with areas of disturbance related to culverts and the associated runoff diversion. The highest average captures 
per 10-stakes on FRF008 was $10.0 \pm 1.7$ and was the section closest to the DAF. The range of average captures on FRF009 was $6.7 \pm 1.5$ to $10.3 \pm 3.1$. A7though areas nearest the sewage lagoon were expected to have lower abundance due to predation by birds and coyotes, there was no correlation nor pattern observed.

Mean capture per 10-stakes (Figure 27) was significantly higher on FRF011 $(10.0 \pm 0.5)$ than either FRF008 $(7.8 \pm 0.8)$ or FRF009 $\left(8.3 \pm 0.5, F_{2.10}=\right.$ 14.08, $P=0.0012)$. A7so, mean capture per 10-stake unit on FRF011 was not uniform $\left(F_{10.22}=2.67, P=0.026\right)$ where two of eleven 10 -stake samples averaged captures $(8.0 \pm 0.0$ and $7.7 \pm 1.5)$ significantly lower than the highest average capture $\left(12.3 \pm 1.5\right.$; Newman-Keuls Multiple Range Test, $q_{20.10}=5.520$ and $\left.q_{20.11}=5.945\right)$. These could not be associated with any habitat differences.

Animal abundance on lines 8 and 9 in late June was similar to that in early June (Tables 23, 24). Since line 11 was not trapped in late June it was not included in any further comparisons but is included in some figures for completeness.

Although half as many traps were set in late June, the same number of individuals was captured on FRF008 as in early June and only 20 fewer individuals were captured in late June on FRF009. The distribution of species captured at both sites also did not change appreciably from early to late June. However, three species captured in low numbers earlier at FRF008 were not captured in 7 ate June. Percent trap success was $61.1 \%$ on FRF008 and $65.3 \%$ on FRF009.

Trap success per 10-stakes $(=$ per 10-traps) increased significantly from early June levels at both plots when captures on 8-10 June were adjusted to per 10stakes by trap-type $\left(F_{3.80}=22.99, P<0.0001\right.$, Figure 28$)$. Mean trap success in late June was not significantly different between the two lines (Figure 28, Newman Keuls, $q_{80.2}=0.606, P>0.05$ ). 


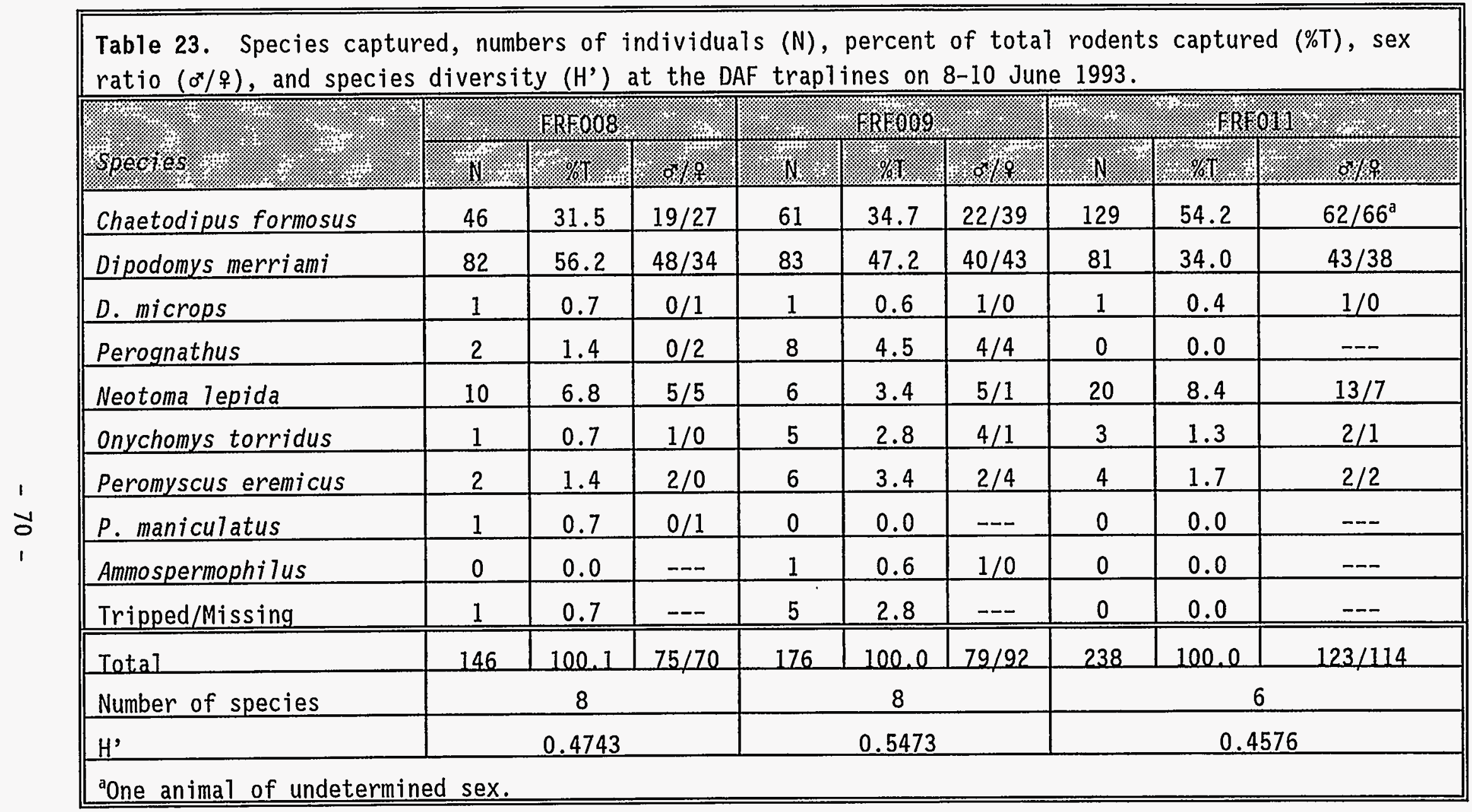




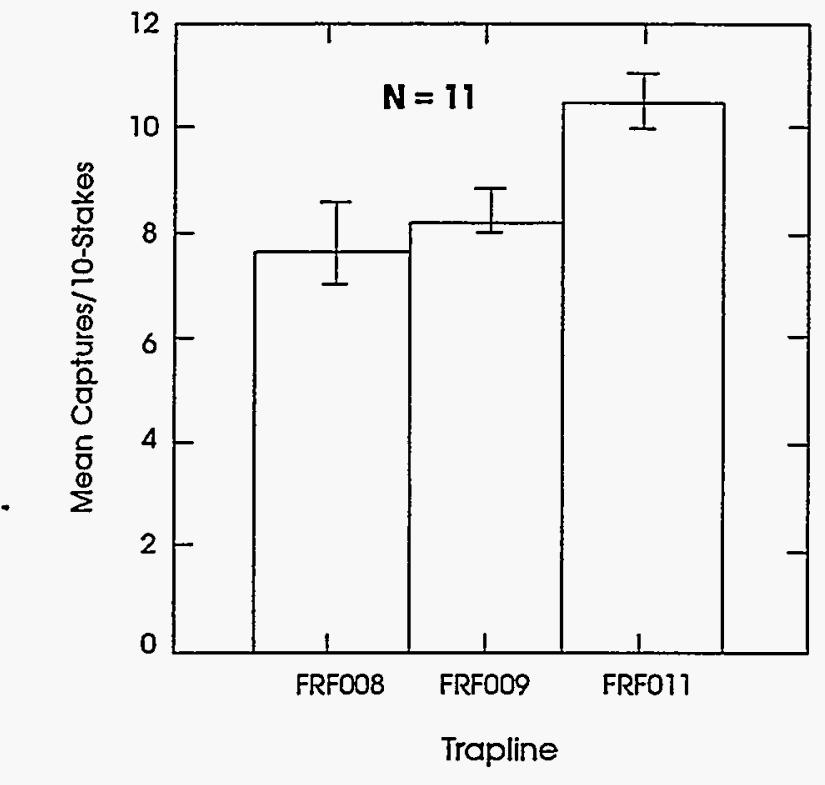

Figure 27 - Mean captures \pm 2 sem per 10-stakes in early June.

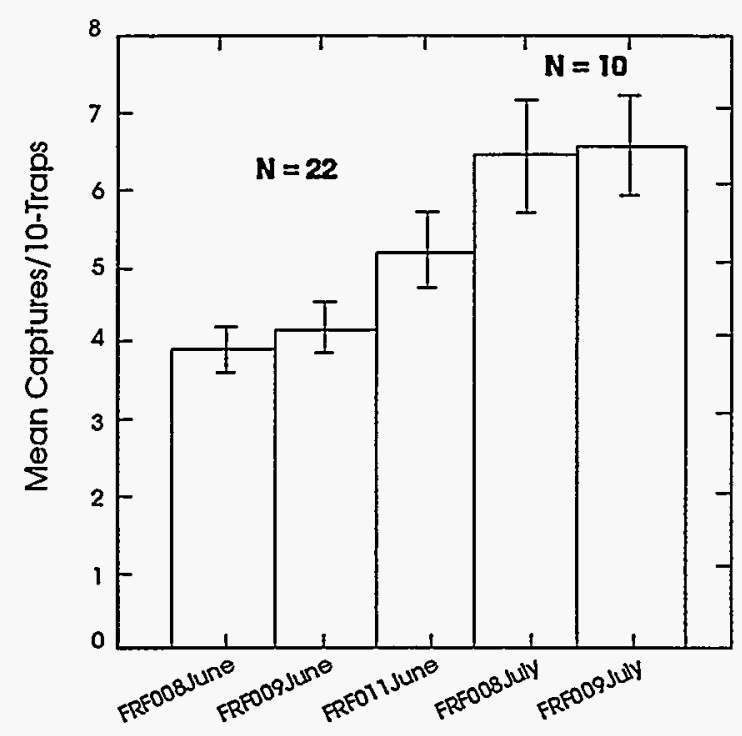

Plot And Time

Figure 28 - Mean captures per 10-stake unit for each plot and trapping date. JUNE $=$ early June, JULY $=1$ ate June. 


\begin{tabular}{|c|c|c|c|c|c|c|}
\hline Spe-1:est: & $\frac{1008}{119}$ & $\frac{19}{4.7}$ & : & 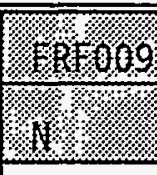 & 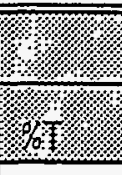 & $\frac{101 \%}{1 \% 1 \%}$ \\
\hline Chaetodipus formosus & 39 & 27.7 & $20 / 19$ & 52 & 33.3 & $30 / 22$ \\
\hline Dipodomys merriami & 85 & 60.3 & $42 / 43$ & 67 & 42.9 & $31 / 36$ \\
\hline D. microps & 0 & 0.0 & -- & 1 & 0.6 & $1 / 0$ \\
\hline Perognathus longimembris & 0 & 0.0 & $-\cdots$ & 9 & 5.8 & $3 / 6$ \\
\hline Neotoma lepida & 6 & 4.3 & $3 / 3$ & 4 & 2.6 & $3 / 1$ \\
\hline Onychomys torridus & 3 & 2.1 & $0 / 3$ & 2 & 1.3 & $1 / 1$ \\
\hline Peromyscus eremicus & 3 & 2.1 & $1 / 2$ & 1 & 0.6 & $0 / 1$ \\
\hline P. maniculatus & 0 & 0.0 & -- & 0 & 0.0 & - \\
\hline Ammospermophi7us leucurus & 4 & 2.8 & $1 / 3$ & 18 & 11.5 & $5 / 12$ \\
\hline Tripped/Missing & 1 & 0.7 & --- & 2 & 1.3 & - \\
\hline Total & 141 & 100.0 & $67 / 73$ & 156 & 99.9 & $74 / 79$ \\
\hline Number of species & \multicolumn{3}{|l|}{6} & \multicolumn{3}{|l|}{8} \\
\hline $\mathrm{H}^{\prime}$ & \multicolumn{3}{|l|}{0.4604} & \multicolumn{3}{|l|}{0.5916} \\
\hline
\end{tabular}

\section{Trap Type}

Given a choice of either a Sherman or mesh trap, rodents did not appear to frequent one trap more than the other $\left(F_{1.64}=2.17, P=0.145\right)$. However, $D$. merriami were captured more often in the mesh traps on 2 of 3 lines while Chaetodipus formosus were captured more frequently in the Sherman traps on 3 of 3 lines (Table 25). In late June, there was no effect of trap type $\left(X^{2}{ }_{c}=\right.$ $0.0081, \mathrm{df}=1, P=0.0717)$ or order of trap presentation $\left(X_{c}^{2}=0.0076\right.$, $\mathrm{df}=$ $1, P=0.0695$ ) on trap success. Mesh traps did have a slight nonsignificantly higher average of new captures (mesh $=2.2 \pm 0.4$, Sherman $=2.0 \pm 0.4 ; t=$ $0.694, \mathrm{df}=29, \mathrm{P}=0.493$ ). 


\begin{tabular}{|c|c|c|c|c|c|c|c|c|}
\hline \multicolumn{9}{|c|}{$\begin{array}{l}\text { Table 25. Total } 3 \text { day captures in mesh }(M) \text { and Sherman }(S) \text { traps at the three DAF traplines on 8-10 June } \\
\text { 1993. }\end{array}$} \\
\hline \multicolumn{9}{|c|}{ 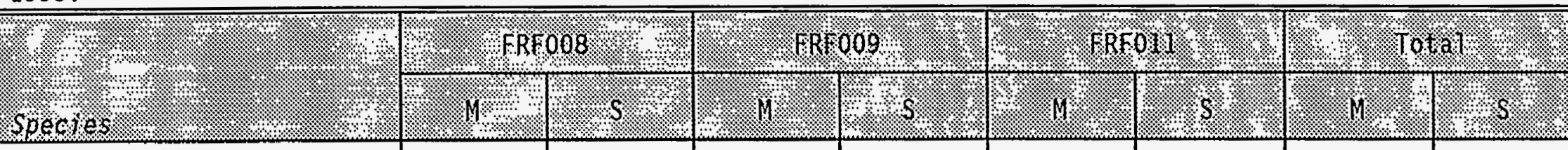 } \\
\hline Chaetodipus formosus & 15 & 38 & 29 & 41 & 62 & 89 & 106 & 168 \\
\hline Dipodomys merriami & 65 & 53 & 59 & 60 & 65 & 40 & 189 & 153 \\
\hline D. microps & 1 & 0 & 1 & 1 & 0 & 1 & 2 & 2 \\
\hline Perognathus longimembris & 0 & 2 & 3 & 5 & 0 & 0 & 3 & 7 \\
\hline Neotoma lepida & 4 & 7 & 2 & 4 & 12 & 12 & 18 & 23 \\
\hline Onychomys torridus & 0 & 1 & 0 & 5 & 1 & 2 & 1 & 8 \\
\hline Peromyscus eremicus & 1 & 1 & 4 & 3 & 2 & 3 & 7 & 7 \\
\hline P. maniculatus & 0 & 1 & 0 & 0 & 0 & 0 & 0 & 1 \\
\hline Ammospermophilus leucurus & 0 & 0 & 0 & 1 & 0 & 0 & 0 & 1 \\
\hline Tripped/Missing & 1 & 0 & 5 & $\underline{\underline{0}}$ & 0 & 0 & $\underline{\underline{6}}$ & 0 \\
\hline TOTAL & 87 & 103 & 103 & 120 & 142 & 147 & 332 & 370 \\
\hline$H^{\prime}$ & 0.3311 & 0.4795 & 0.4472 & 0.5488 & 0.4444 & 0.4492 & 0.4725 & 0.5166 \\
\hline
\end{tabular}


One significant difference between trap types was the number of torpid/dead animals. Pooling plots and dates $\left(N_{\text {mesh }}=15, N_{\text {Sherman }}=15\right)$, significantly more animals $\left(F_{1.28}=14.63, P=0.00067\right)$ were torpid or dead per day in the mesh $(8.1 \pm 3.3$, total $=122)$ than the Sherman $(1.5 \pm 0.8,23$ animals $)$. Since season may have an effect on torpidity, time of trapping was partitioned out to directly compare early and Tate June, FRF011 was excluded (Figure 29). A twoway ANOVA showed that trap type $\left(F_{1.20}=26.16, P=0.00005\right)$ but not season $\left(F_{1.20}=2.91, P=0.104\right)$ had an effect, with no significant interaction term $\left(F_{1.20}=0.39, P=0.537\right)$.

An added deleterious trait of the mesh trap was that they were easily picked up by coyotes and crushed open. Six mangled and bloody traps (Figure 30) were retrieved more than 30 meters from a stake and an additional three could not be located. While a few Sherman traps were also moved, animals were usually still inside the trap. OnTy one Sherman trap was found bloody and empty.

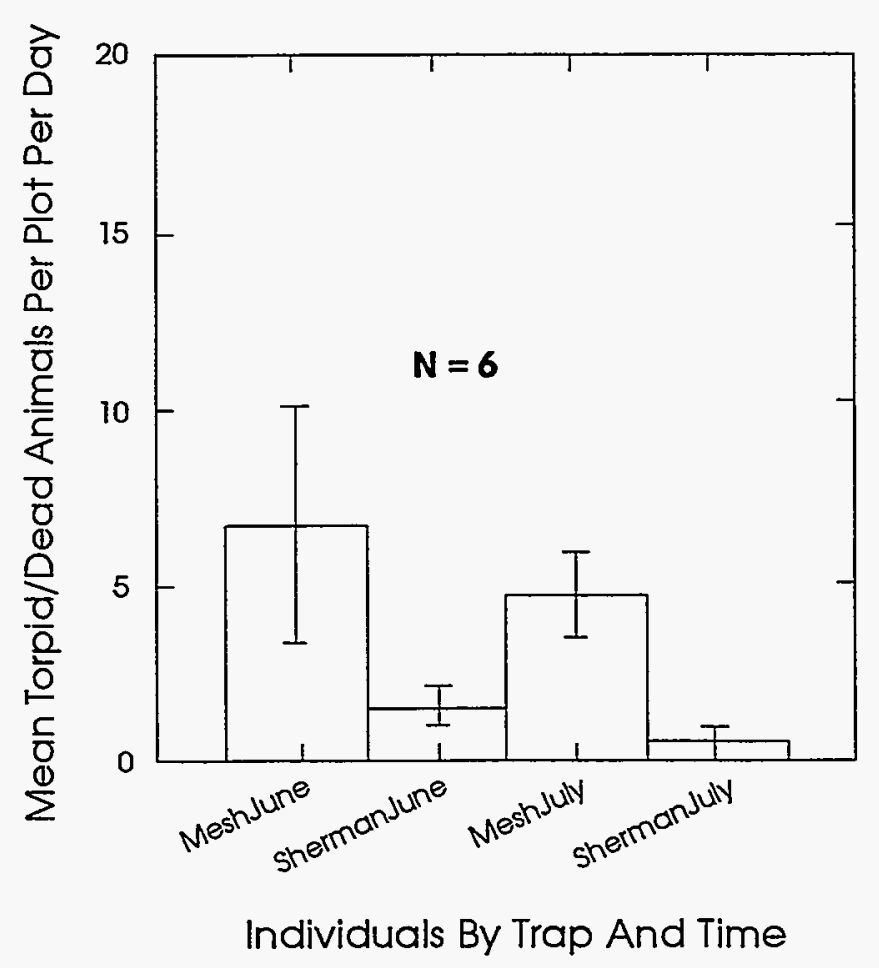

Figure 29 - Mean number of torpid/dead animals captured by trap type at plots 8 and 9 in early (JUNE) and late (JULY) June. 


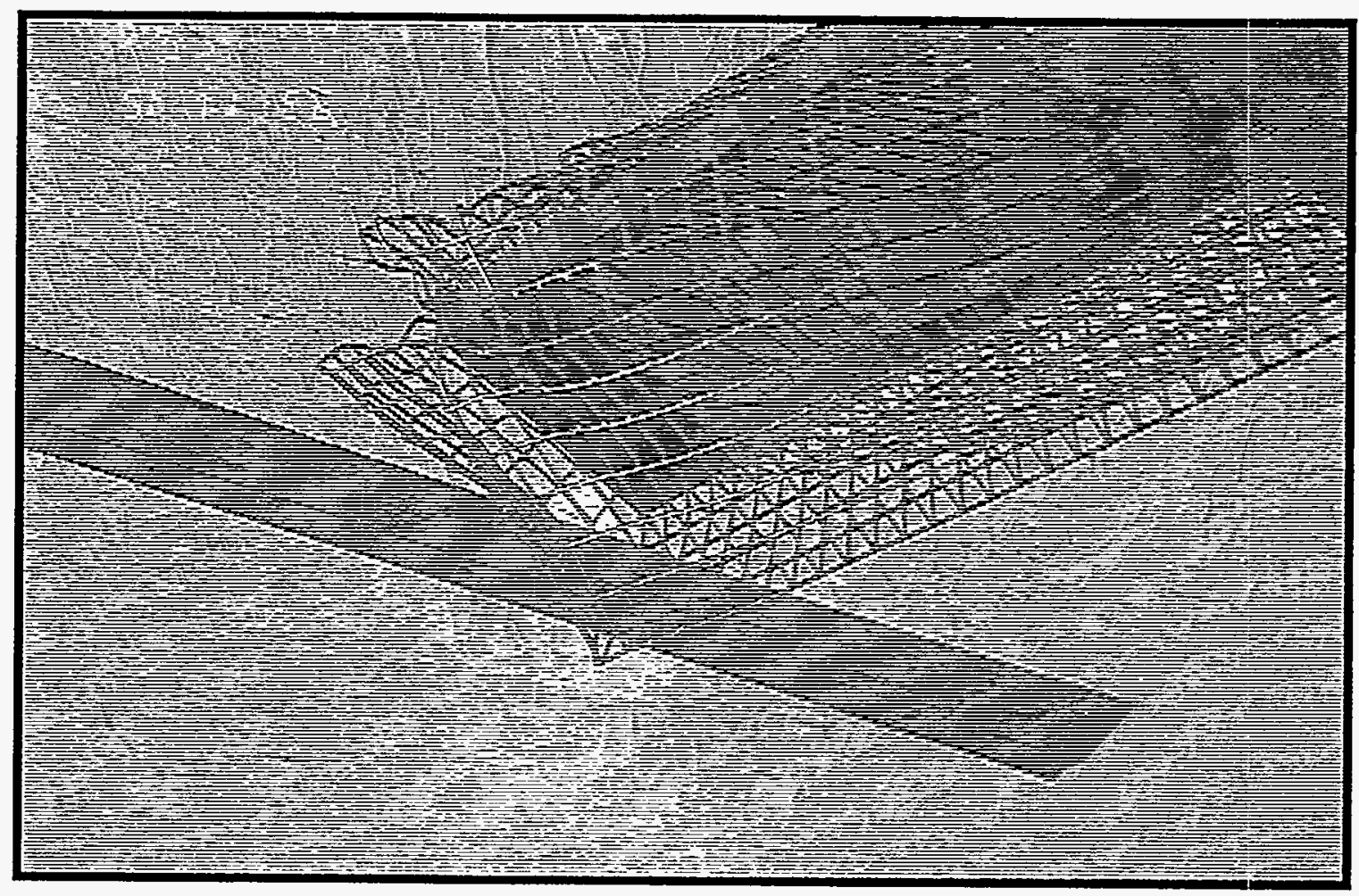




\section{Reproduction}

For sites 8 (roadside) and 9 (control) in early and late June there was a significant difference between mean weights of adult Dipodomys merriami for the four samples $\left(F_{3.199}=4.45, P=0.005\right)$ but not $\operatorname{sex}\left(F_{1.199}=0.53, P=\right.$ $0.468)$. There was also evidence of an interaction $\left(F_{3.199}=3.13, P=0.027\right)$. Adult females are the real test of reproduction: in general females weigh less than males during hiatus from reproduction and increase in weight approaching that of males during bouts of reproduction (Kenagy 1973). The above results indicate that females were indeed close to males in mean weight (Table 26).

Table 26. Mean weight ( $\mathrm{g} \pm 1 \mathrm{sd}$ ) of adult $D$. merriami at FRF008 (roadside) and FRF009 (control) in early and late June. Numbers in parentheses are number of individuals weighed.

\begin{tabular}{|c|c|c|c|c|c|}
\hline Sex & Early & Late & Early & Late \\
\hline Male & $\begin{array}{c}41.6 \pm 4.6 \\
(34)\end{array}$ & $\begin{array}{c}41.1 \pm 4.7 \\
(29)\end{array}$ & $\begin{array}{c}42.7 \pm 3.2 \\
(29)\end{array}$ & $\begin{array}{c}41.0 \pm 3.7 \\
(20)\end{array}$ \\
\hline Female & $\begin{array}{c}43.2 \pm 4.6 \\
(26)\end{array}$ & $\begin{array}{c}43.6 \pm 4.0 \\
(22)\end{array}$ & $\begin{array}{c}42.8 \pm 4.4 \\
(24)\end{array}$ & $\begin{array}{c}38.6 \pm 5.0 \\
(23)\end{array}$ \\
\hline Male +Female & $\begin{array}{c}42.3 \pm 4.6 \\
(60)\end{array}$ & $\begin{array}{c}42.1 \pm 4.5 \\
(51)\end{array}$ & $\begin{array}{c}42.8 \pm 3.7 \\
(53)\end{array}$ & $\begin{array}{c}39.7 \pm 4.5 \\
(43)\end{array}$ \\
\hline
\end{tabular}

Female $D$. merriami at FRFOO9 in late June had a significantly lower mean weight than females at 8 and 9 in early June and at 8 in late June $\left(F_{3.91}=\right.$ $6.14, P=0.001)$. This was not true for the males $\left(F_{3.108}=1.00, P=0.394\right)$ and might indicate females were no longer reproductive along 7 ine 9 .

The distribution of weights at the DAF sites appeared to be bimodal with peaks between 25 to 30 and 40 to 45 grams. This was not true for FRF009 in 7 ate June (Figures $31-35)$, which had a significantly different distribution $\left(X^{2}\right.$ $=70.651,32$ d.f., $P=0.0001$ ). There is the possibility of a greater dispersal or mortality of adults from the area around FRF009 since a greater proportion of the $D$. merriami at this site in late June were in the 30 to 40 gram weight class (Figure 34 ). 
It is more likeiy that on the roadside this species experienced a lag or extra bout in reproduction as shown by the distribution of female reproductive status (e.g. pregnant or lactating, nonreproductive, or immature juvenile). Since males (except very immature juveniles) may exhibit scrotal testes during most of the year (Bradley and Mauer 1971; Reichman and Van De Graaff 1973) and therefore may not be accurately designated as reproductive or not, only females were tested.

The percentage of reproductive females on plot 8 in early June was two times as high as on plot 9 (Figure 36). The opposite was true for the females ranked as juvenile, with line 11 falling in the middle. In late June the same percentage of females were judged to be reproductive on each plot with a slightly greater proportion of juveniles present on 7 ine 8 . The distribution of females was significantly different on plot 8 in early June from the other three samples $\left(X^{2}=12.913,6\right.$ d.f., $\left.P=0.044\right)$. The ratio of new juveniles to new adults at FRF008 in late June (22/8) was significantly greater than that from FRF009 in Tate June $(11 / 9) ; X^{2}=4.089,1$ d.f., $P=0.045$.

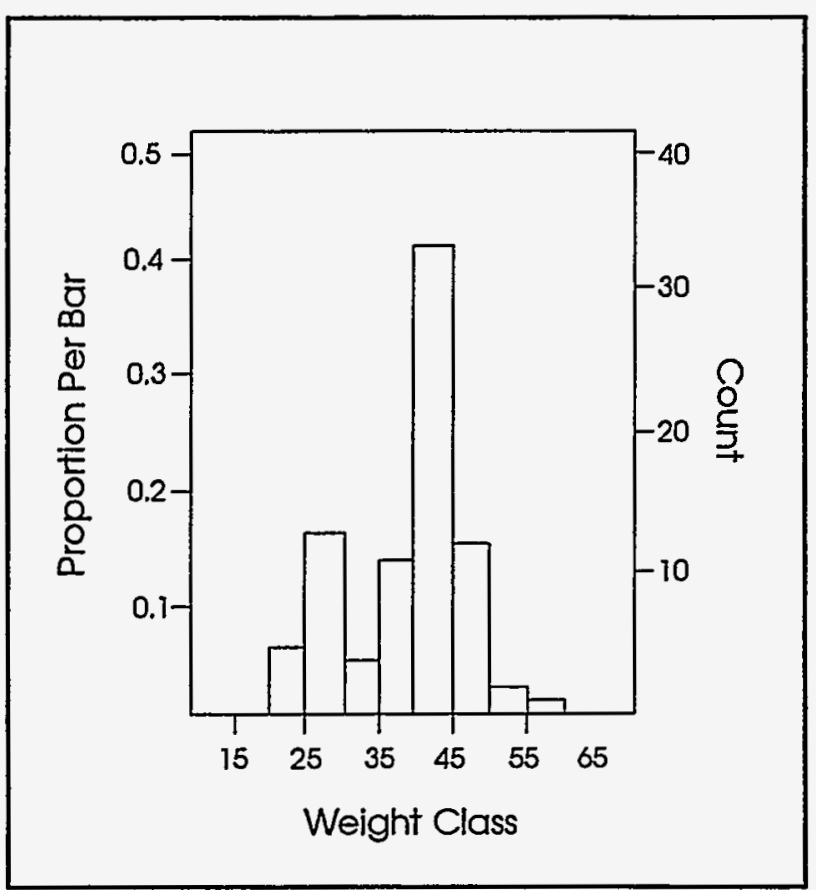

Figure 31 - Distribution of D. merriami weights at FRFO08 in earty June.

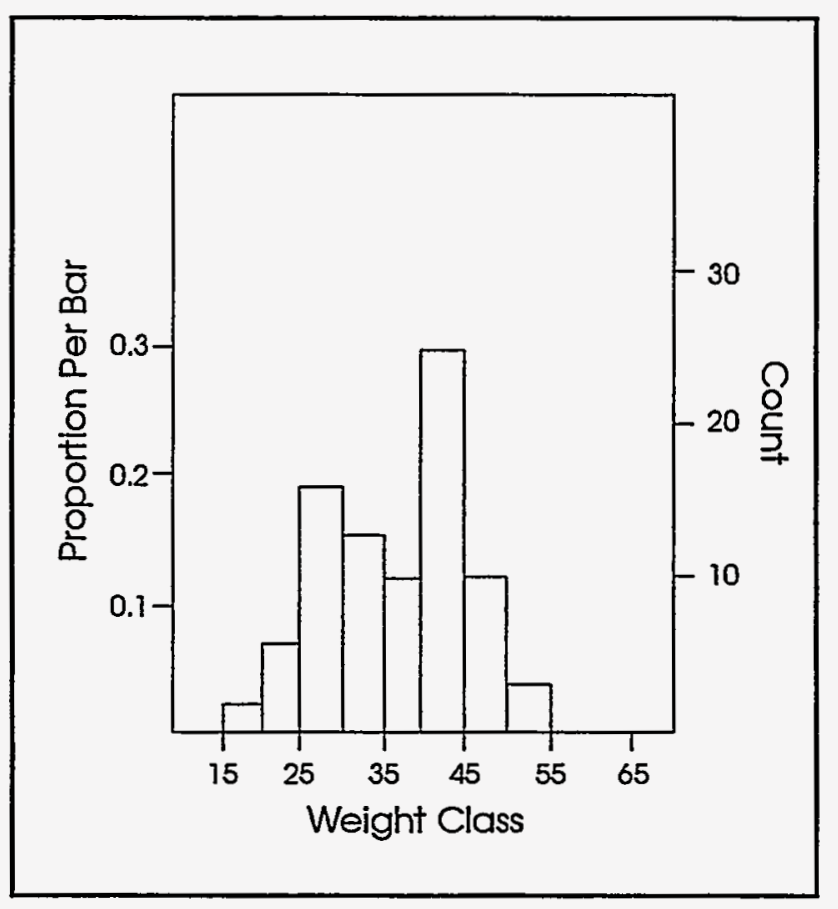

Figure 32 - Distribution of D. merriami weights at FRFO08 in late June. 


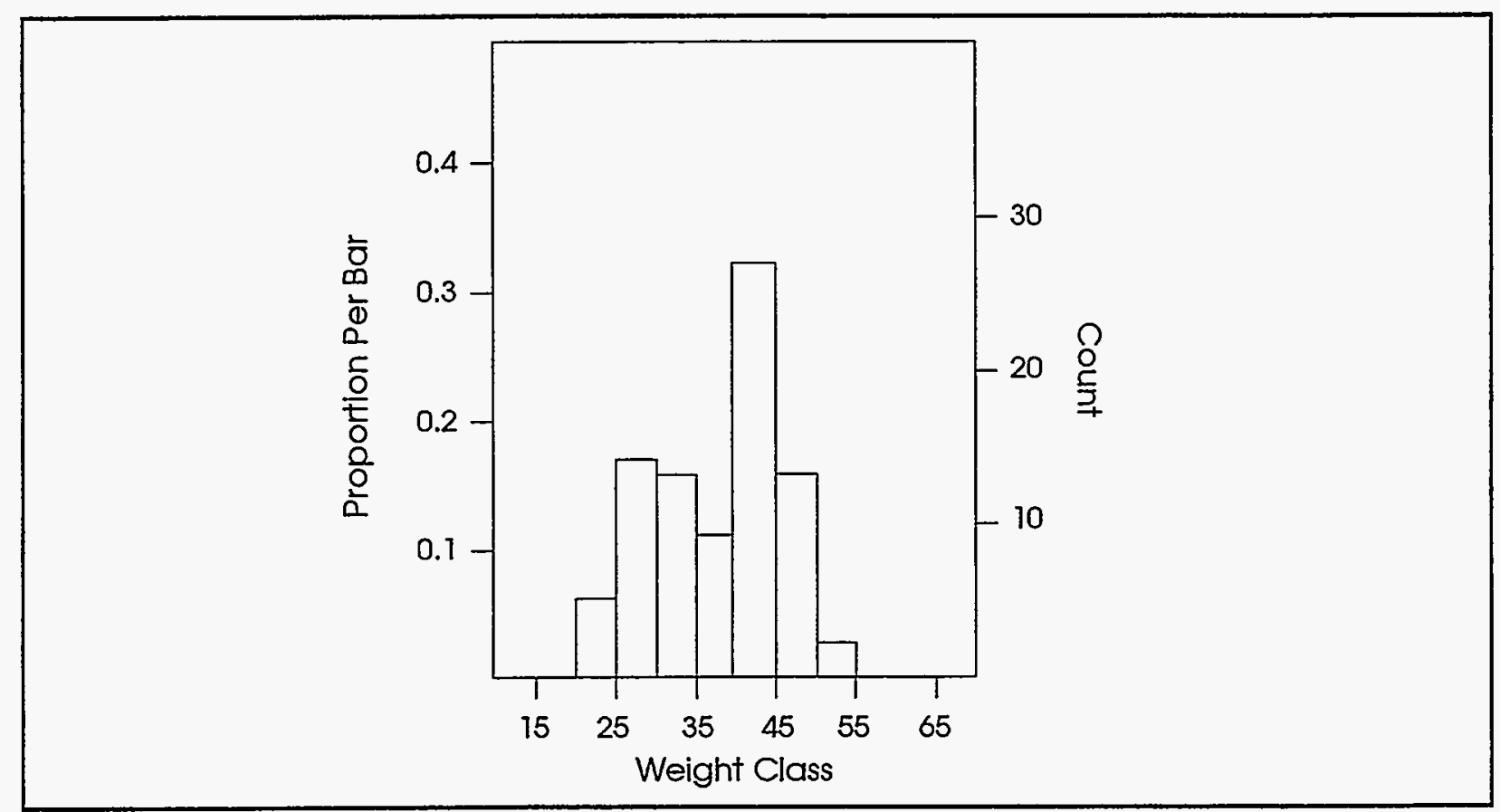

Figure 33 - Distribution of D. merriami weights at FRF009 in early June.

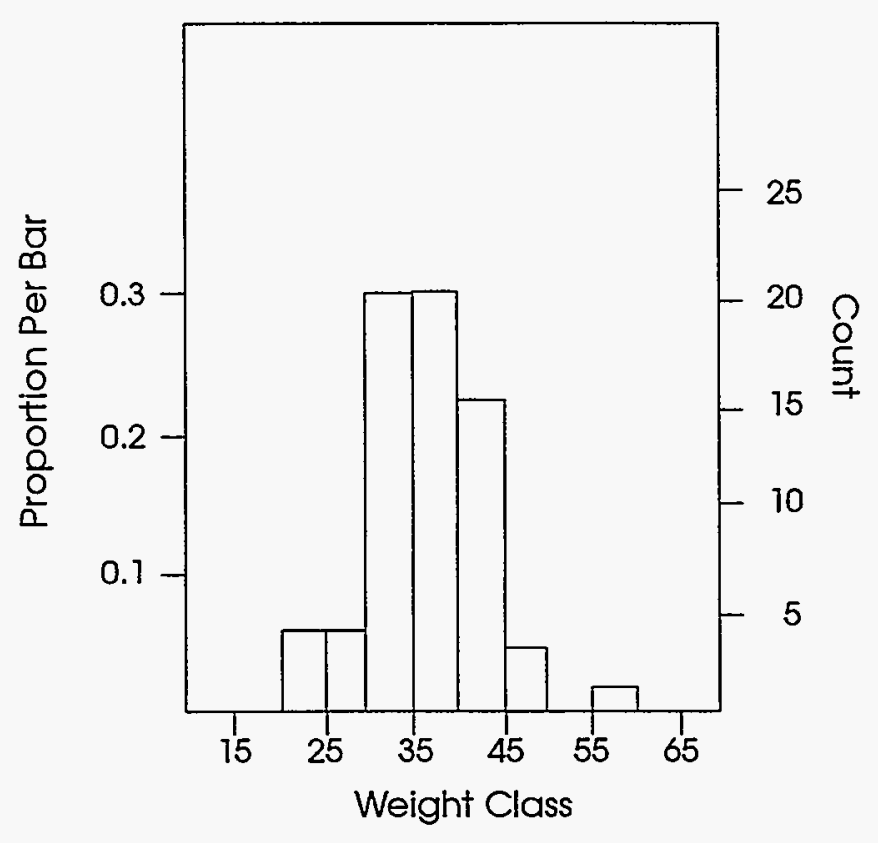

Figure 34 - Distribution of D. merriami weights at FRF009 in Tate June 


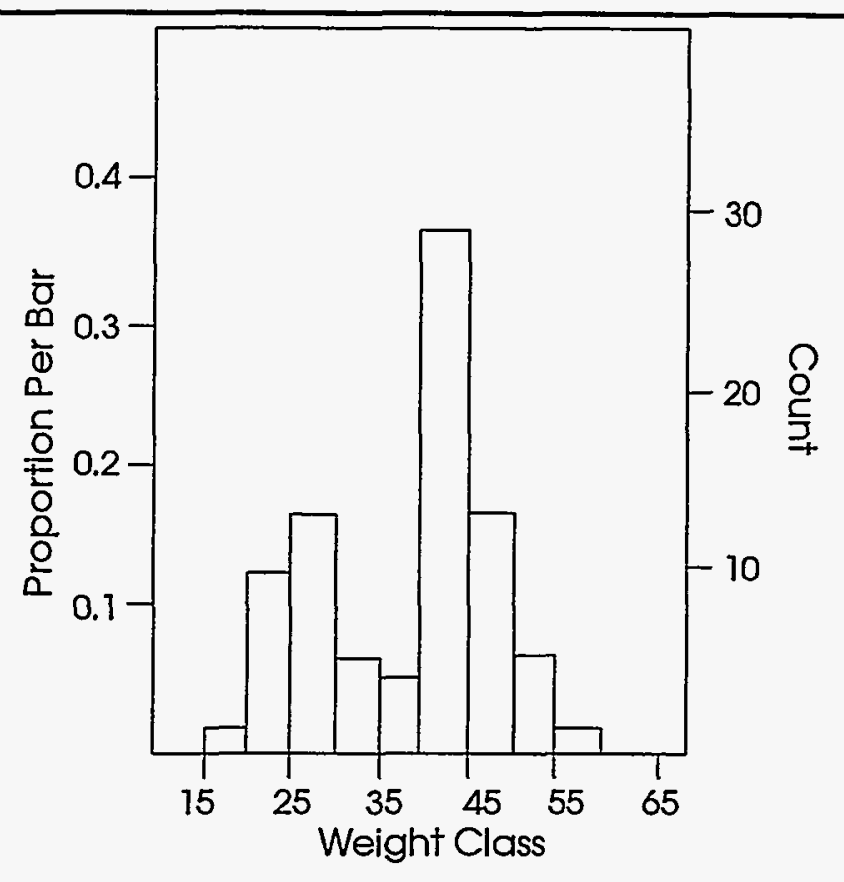

Figure 35 - Distribution of D. merriami weights at FRF011 in early June.

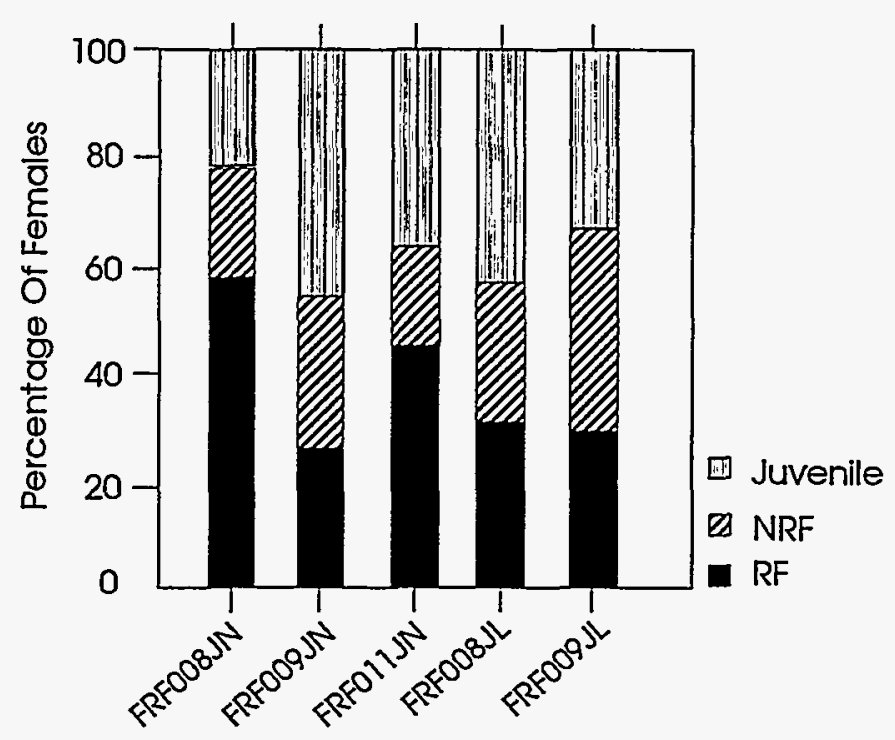

Plot And Trap Session

Figure 36 - Reproductive status of female D. merriami captured at the DAF in early (JN) and late (JL) June. R=reproductive, NR=nonreproductive, J=juvenile. 
While it appears that there is some significant impact of the road on the $D$. merriami population, it is unclear whether these results indicate a benefit or detriment. Had FRFO11 been trapped in late June for a comparison to another undisturbed area, the results may have been clearer. More intense and regular trapping is needed to determine the cause as well as the direction of the effect.

Looking at the second most abundant rodent at these two sites, Chaetodipus formosus, a different pattern emerged. Mean wejght of al1 rodents differed across samples $\left(F_{3.189}=4.05, P=0.008\right)$, but not across sexes $\left(F_{1.189}=0.64, P\right.$ $=0.424$ ) there also was no interaction, $\left.F_{3.189}=0.62, P=0.602\right)$. The late June mean weights of 8 and 9 were significantly greater than the early June weights at 8 and 9 . When juveniles were excluded there were no significant comparisons (sample: $F_{3.146}=0.58 P=0.627$; sex: $F_{1.146}=0.29, P=0.589$; interaction: $\left.F_{3.146}=0.59, P=0.625\right)$.

In 211 cases, a unimodal distribution of weights was observed. However, the distribution of weights for plots 8 and 9 appeared to increase slightly from early to late June (Figures $37-41$ ). This clearly indicates that the reproduction of $C$. formosus was synchronous at the roadside and control 1 ines.

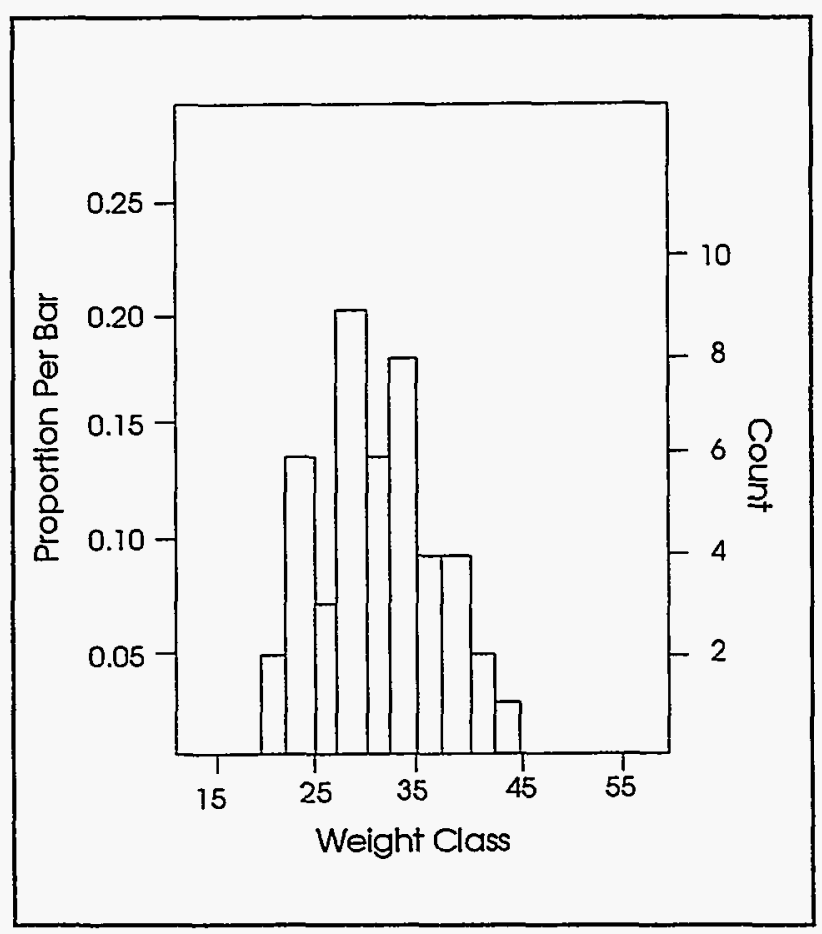

Figure 37 - Distribution of C. formosus weights at FRF008 in early June.

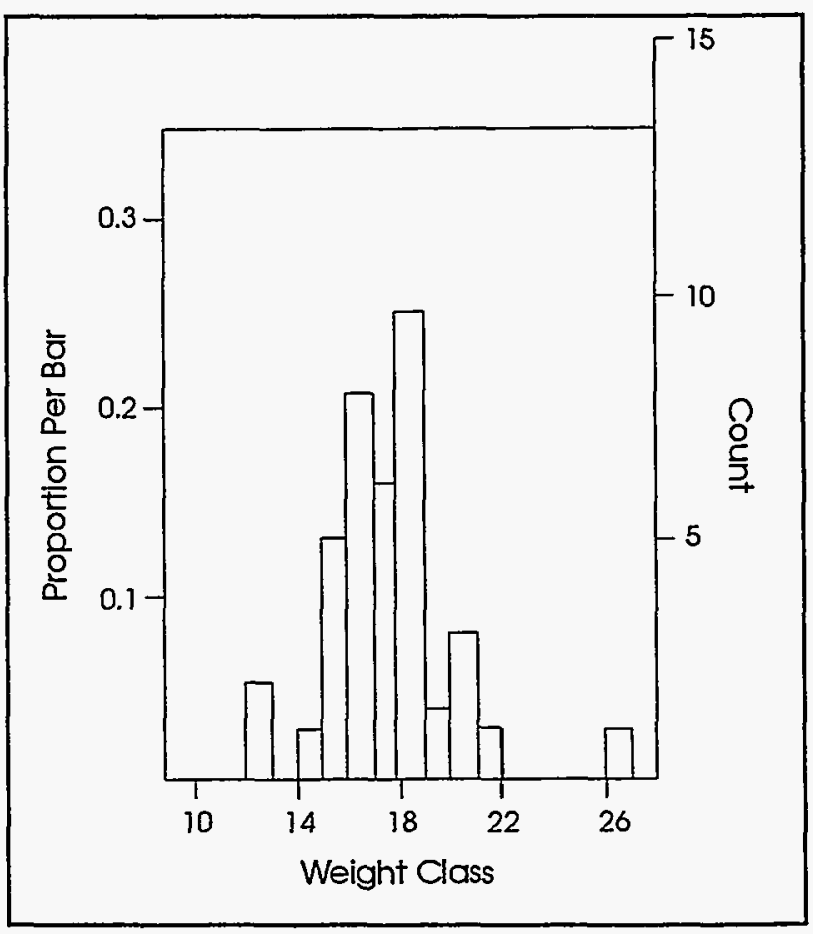

Figure 38 - Distribution of $C$. formosus weights at FRFO08 in late June. 


\section{Bat Species}

The only bat captured at the sewage lagoon was the western pipistrelle (Pipistrel7us hesperus). Several larger pale bats, possibly Antrozous pallidus or Plecotus townsendii, were observed but never caught. High winds had a negative impact on the effectiveness of the nets.

Mammal trapping and mist netting revealed no species of special concern within the DAF study area. Two federal candidate species that may occur on the NTS are the Pygmy rabbit (Sylvilagus idahoensis) and the spotted bat (Euderma maculatum). The preferred habitat for the pygmy rabbit is tall sagebrush, which does not occur near the DAF and therefore it is highly unlikely that this species would be encountered here. Little is known about the habitat requirements for the spotted bat and it is possible that this species may utilize the DAF area, particularly for foraging moths attracted to the building lights.

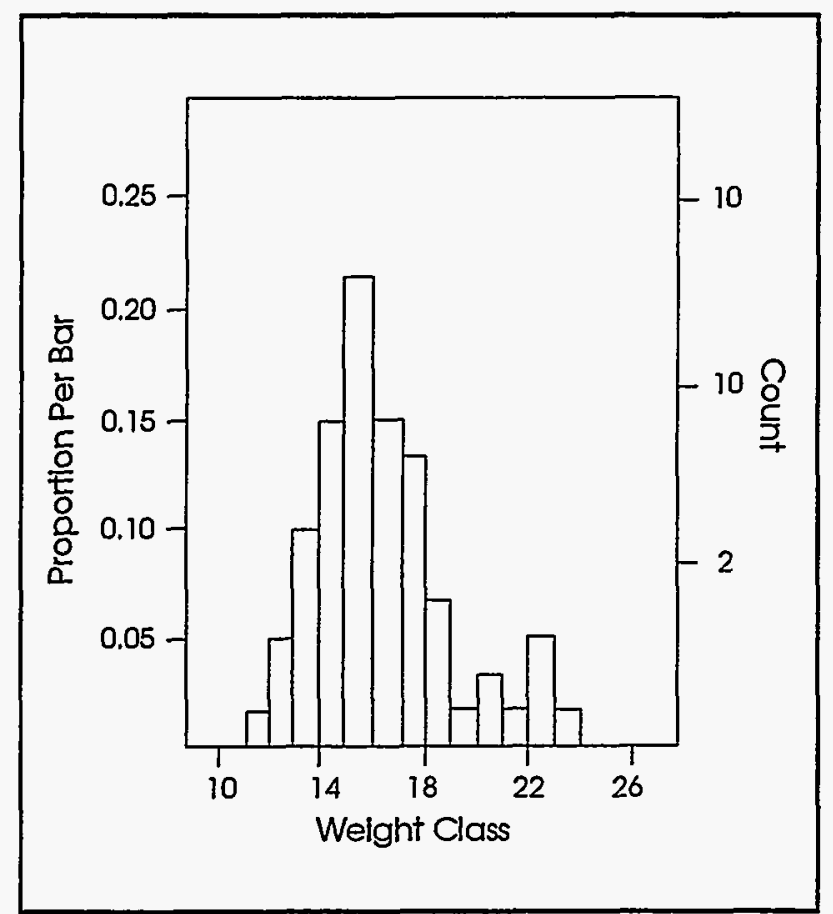

Figure 39 - Distribution of $C$. formosus weights at FRF009 in early June.

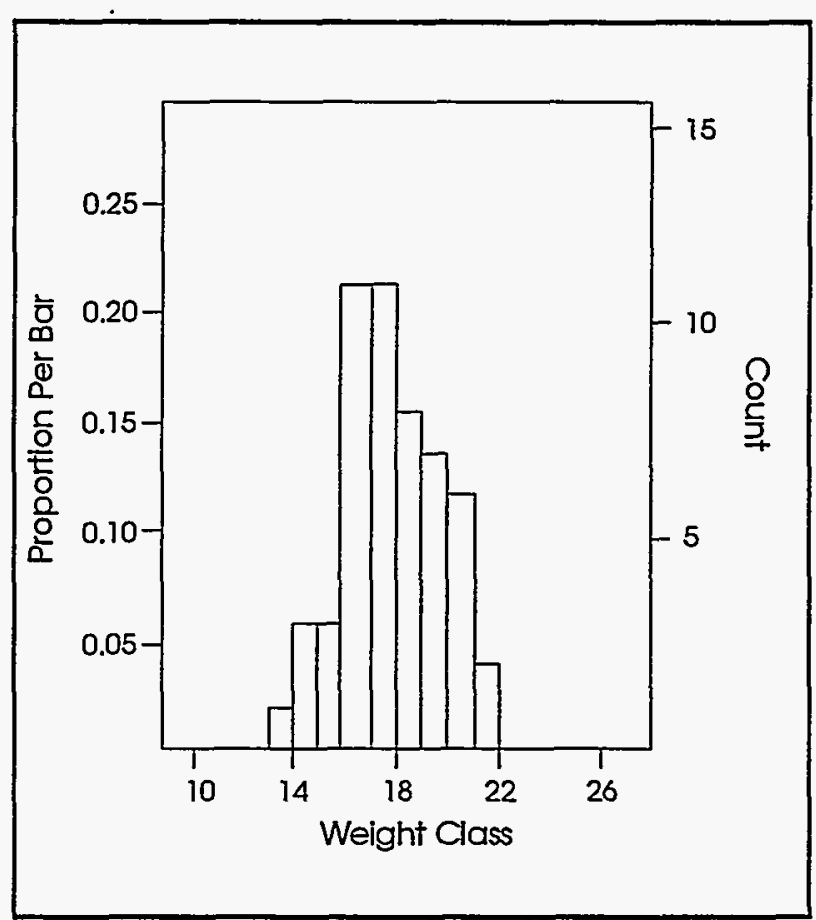

Figure 40 - Distribution of C. formosus weights at FRFO09 in late June. 


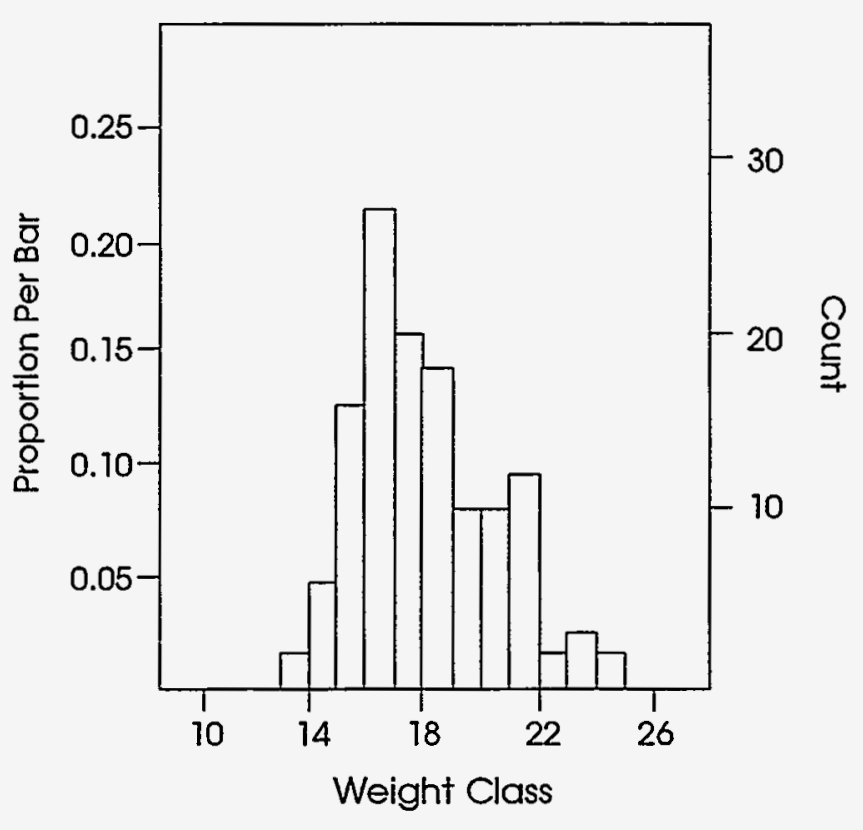

Figure 41 - Distribution of C. Formsus weights at FRF011 in early June.

\section{DISCUSSION}

\section{EPHEMERALS}

\section{Ephemeral Techniques}

One of the main goals of the DAF ephemeral sampling was to assess techniques. A11 ephemeral sampling techniques used were inadequate in some respects. The standard BECAMP technique (20 quadrats, nested to $1000 \mathrm{~m}^{2}$ ) provided detailed information on the most common species, but the results were applicable only to the $1000-m^{2}$-areas actually sampled. It was too time-consuming to do multiple sites, and it gave little data (presence/absence only) on most species. Use of a second technique (ten quadrats nested to $100 \mathrm{~m}^{2}$ ) saved a sma11 amount of time, but the three sites monitored took $1 \frac{1 / 2}{2}$ days to census, preventing its use at many replicate locations. It suffers from the same problems as the standard technique, in that results were applicable only to the sites studied, and statistical inferences could be made only for the most common species.

The $\log _{10}$ observations (Figures $4-8$; Table 5) provided coarse density information for common species near the paved road. It was rapid enough to 
sample random spots along the whole length of the paved road, and the information is therefore applicable to the road and its use and maintenance, not just to the particular site studied. No information was collected on mean plant size, biomass, or reproduction, which limits suggestions as to causes of road-engendered effects on ephemerals. This technique also did not distinguish between densities of rare (density $<5 / \mathrm{m}^{2}$ ) and absent (density $=0$ ) plant species.

The $\log _{2}$ technique of estimating density was inadequate on several grounds. Untike the standard technique it provided a density estimate for each species (Table 6), but those density estimates lacked statistical error estimates. Location of the first encountered plants of a species largely determined the density estimates. Absence of replicates prevented averaging across many samples, which would reduce the calculated density from that first occurrence. Expected time savings were unrealized. The method took 6 hours for two sites, as long as standard techniques.

These observations are important because DAF monitoring is somewhat different from that on most other NTS areas. It is a central location from which influences may spread radially outward, in contrast to blasted or burned areas, subsidence craters, or waste dumps, whose primary influences may be limited to the disturbed areas or extend only short distances from them (e.g., roads). It would be preferable to have numerous plots set up randomly at many different distances and directions from the DAF, as was done for perennial plants. Techniques need further modification before that can be accomplished in the short time available for sampling ephemerals.

\section{Ephemeral Populations in 1993}

Ephemeral populations measured near the DAF in 1993 were unusually rich in species, had good growth, and exhibited mixed dominance, depending on location. The number of species was high both in undisturbed and disturbed habitats (Table 27). The difference in mean species numbers on DAF and BECAMP plots was significant $(t=3.14, d . f .=6, P=0.020)$ but the data were not strictly comparable because of technique differences among the DAF plots. The wide dispersal of the $1 \mathrm{~m}^{2}$ quadrats with the $\log _{10}$ technique may have increased the numbers of species seen. Nevertheless, seeing 51 species on the scraped and graveled area, and 48 on the dirt road to the water tank was surprising. 


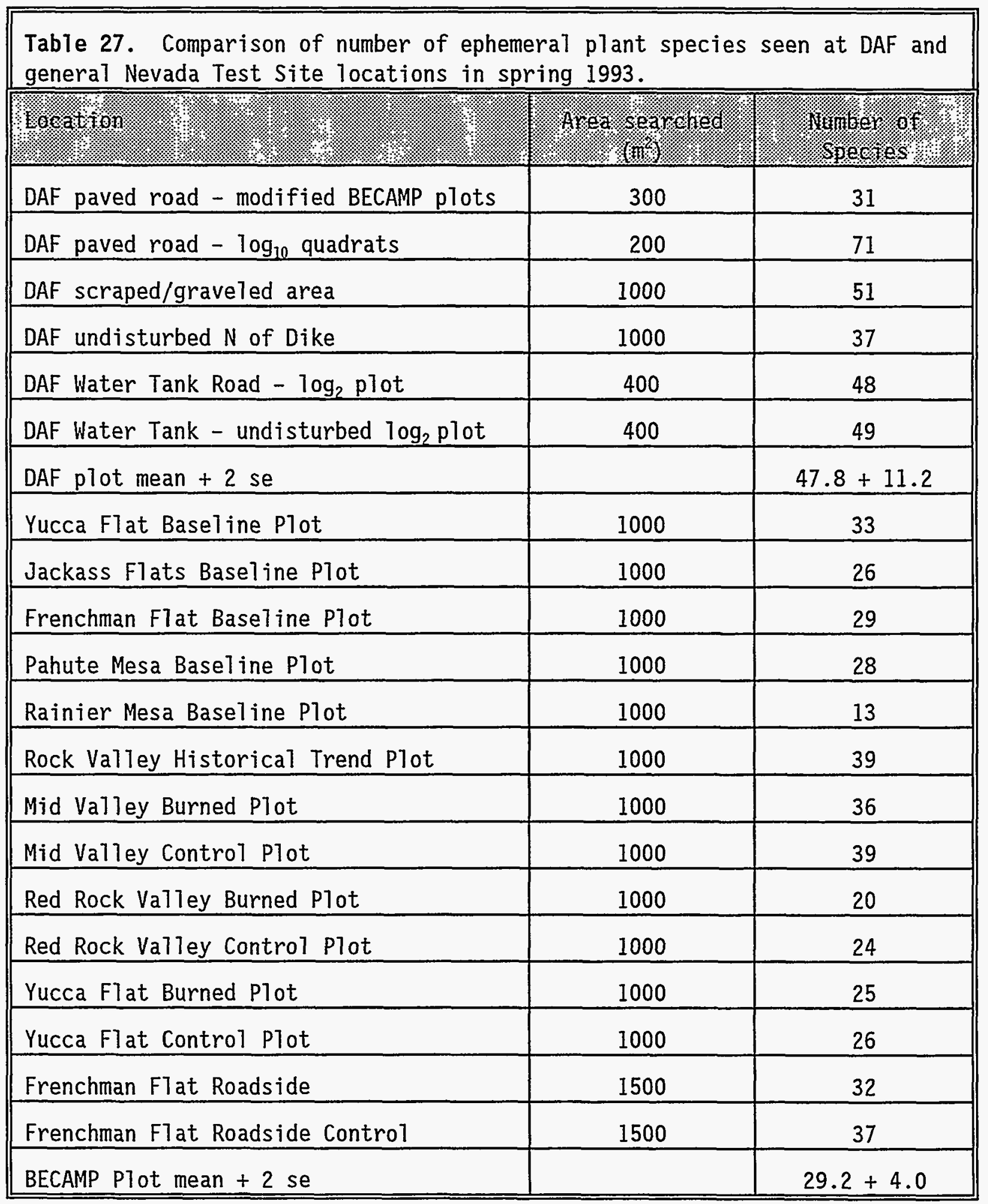


There are several possible reasons for the high species richness near the DAF. First, the DAF is situated near the boundary between two shrub "communities", one dominated by Larrea tridentata (creosotebush) and Ambrosia dumosa (white bursage) and the other by Coleogyne ramosissima (blackbrush) and Yucca brevifolia (Joshua tree). These communities are mixed together in the vicinity of the DAF, and it is possible the ephemeral plant community is responding to the mixed perennial populations. Alternatively, there might be more habitat variation near the DAF, perhaps associated with the slopes and drainage channels. Another possibility is that Bromus rubens, an introduced grass now dominant over many NTS areas, grew to dominance more slowly in the vicinity of the DAF, and thus has had less effect on native populations. None of these hypotheses is particularly plausible, and none explains the high number of species on some of the disturbed areas sampled near the DAF.

Rainfall in the 1992-1993 ephemeral season was unusua77y high, and ephemeral plants all over the NTS grew we17. It is not plausible that weather near the DAF was more favorable to germination than in other areas. However, many species seen in 1993 may not be seen again for many years because 1993 was an unusually good year.

Biomass production by ephemerals on undisturbed sites (DAF1, DAF3) was $40 \pm$ $26 \mathrm{~g} / \mathrm{m}^{2}$ and $52 \pm 21 \mathrm{~g} / \mathrm{m}^{2}(\bar{x} \pm 2 \mathrm{se})$. Data of Turner and Randal1 (1989) for Rock Valley during the early 1970 's suggest that the $288 \mathrm{~mm}$ of rain which fell (at Cane Springs, 7 miles from the DAF) should have produced $107 \mathrm{~g} / \mathrm{m}^{2}$. It is difficult to explain the difference between their predictive equation, which is based on September to March rainfal1 ranging from 43 to $220 \mathrm{~mm}$, and the DAF results. In Rock VaTley, Turner and Randa11's equation predicted 1988-1991 ephemeral production somewhat below actual production, but always within 10 $\mathrm{g} / \mathrm{m}^{2}$ (Hunter 1994a). Some variables which might relate to the difference are soil fertility, rainfall timing, shrub competition, surface aspect, and reduction in seed reserves during the 1989-90 drought.

The significant differences in weight per plant found among the roadside plots (Table 4) and between the scraped and undisturbed areas (Table 3) are explainable as effects of plant density, soil compaction, and species differences. 


\section{Effects of Disturbances on Ephemeral Populations}

Disturbances examined near the DAF included the scraped/graveled area west of the DAF, the verge of the paved road, and the dirt road leading to the DAF water tank. These construction/operation disturbances can be expected to have major influences on ephemeral populations where they occur, and to an unknown extent may affect populations off the disturbed area. The technique which best demonstrated such effects was the $\log _{10}$ density estimation used near the paved road. Results suggest road construction, maintenance, and use are responsible for dense concentrations of Eriogonum deflexum found there, and by implication construction disturbances are probably responsible for the dense $E$. deflexum populations common near the DAF. This is not unique, as $E$. deflexum has recently been increasing on NTS disturbed areas. In 1992 it was the most common species on a scraped/compacted area in Mid Valley and also on a shrub-removal plot in Mercury (Hunter 1994b). Al1 that appears required for increase in $E$. deflexum is removal of shrubs, as that was the only disturbance to the Mercury plot.

The road also appears to be a site of increase for Schismus arabicus, an introduced grass which has not become dominant on the NTS, although it is dominant at lower elevations in the Mojave Desert (Hunter et al. 1987). It has been present on the NTS at least since 1959, as indicated by specimen \#558 in the NTS herbarium. Near Daggett, California it occurs widely in the desert at densities high enough to compete significantly with native species. Its presence along the DAF roadside probably indicates a combination of favorable factors, including the absence of shrubs caused by scraping the roadside, import of seeds by vehicie traffic, runoff from the pavement adding extra water from light rains, and increased winter temperatures related to the south-facing slope on the road shoulder. It was the densest species on the Mercury shrub-removal $\mathrm{p} 7$ ot in 1993 , at $2040 \pm 976 / \mathrm{m}^{2}(\bar{x} \pm 2$ se). Its absence from the vicinity of the DAF except for the roadside suggests either that it cannot persist in undisturbed desert, or that it has only been recently introduced and has not spread far near the DAF.

Another introduced species found along the DAF paved road in small numbers was Halogeton glomeratus. This is a toxic weed found in recent years on scraped areas on Pahute Mesa, where it appears to be spreading significantly into undisturbed sites. It has also in recent years increased in abundance along the Mercury Highway. 
Halogeton is related to another weed common on disturbed areas all over the NTS, Salso7a australis (Russian thistle). Salsola was present $\left(8 \pm 7\right.$ per $\mathrm{m}^{2}$ $; \bar{x} \pm 2 \mathrm{se}$ ) on the scraped/graveled area (DAF6) west of the DAF, where it can be expected to be dominant in future years. It is well adapted to growing on disturbed areas, in contrast to the native species.

\section{PERENNIAL PLANTS}

Perennial vegetation on the NTS has been in a state of constant change since the current monitoring program began in 1987 (Hunter and Medica 1989; Hunter 1992b, Hunter 1994c, d). Severe drought in 1989 and 1990 resulted in death of most of the perennial grasses and herbaceous perennials and many of the smaller shrubs in the Mojave and Transition deserts (Hunter 1994c). Partial recovery occurred in 1992 and 1993, with regrowth of some of the drought-hardy perennials and germination of a few shrubs and many grasses (Hunter 1994d). Beatley (1979) reported only minimal changes in shrub populations between 1963 and 1975. Her study period straddled a drought in 1971 and 1972 which apparentiy did not result in significant shrub death. Beatley did not report data on herbaceous perennials and grasses.

Around the DAF there were no studies prior to 1993 except at one of Beatley's plots (\#27; Nevada Grid Coordinates N780123, E681009). She reported 16.8\% cover by shrubs in 1963, and $18.9 \%$ in 1975, but species composition was lumped with that of six other plots with similar vegetation (Larrea-Lycium-Grayia), and actual conditions near the DAF cannot be determined from her report.

Total live cover on the 100 BECAMP plots around the DAF was $14.1 \%$ (Table 3), but that number is based on different techniques from Beatley's and is not strictly comparable to her cover values. On the seven lumped plots, Beatley found averages of 7 of 91 shrubs dead in $1963(8 \%)$ and 8 of $106(8 \%)$ in 1975. In 1993640 of 1087 shrubs were dead (59\%). The difference in percent dead across the three years was significant $\left(X^{2}=175,2\right.$ d.f., $\left.P<0.001\right)$.

Shrubs which died in the recent drought were not random, but were concentrated among particular species (Table 28). (The proportions of live and dead shrubs differed across 8 non-herbaceous species examined, $X^{2}=177,7$ d.f., $P<$ 0.001.) OnTy a few dead Larrea tridentata and Krameria parvifolia were found, but most Coleogyne ramosissima, Grayia spinosa, and Ephedra nevadensis were dead. Surviving Ephedra occurred in smal1 washes and at the edges of disturbed areas. Only two plots NE of the DAF were in locations previously dominated by Coleogyne ramosissima, but in those areas the Larrea and Ambrosia 
survived while most of the Coleogyne died. These data are evidence of recent change in the perennial plant communities around the DAF towards a more drought-hardy composition, as Mojave Desert species became more dominant, and transition desert species less so.

Table 28. Live and dead shrubs censused in 1993, by species, on $1000 \mathrm{~m}^{2}$ of plant transect within $1500 \mathrm{~m}$ of the DAF.

\begin{tabular}{|c|c|c|c|}
\hline Spectes & 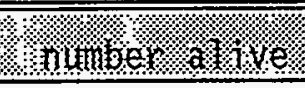 & 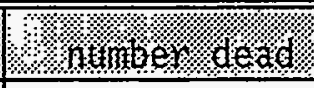 & 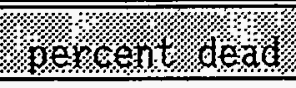 \\
\hline Ambrosia dumosa & 159 & 79 & 33 \\
\hline Atriplex confertifolia & 39 & 11 & 22 \\
\hline Coleogrne ramosissima & 1 & 5 & 83 \\
\hline Ephedra nevadensis & 8 & 36 & 82 \\
\hline Grayia spinosa & 7 & 43 & 86 \\
\hline Krameria parvifolia & 84 & 7 & 8 \\
\hline Larrea tridentata & 77 & 11 & 12 \\
\hline Lycium andersonij & 27 & 15 & 36 \\
\hline Menodora spinescens & 16 & 37 & 70 \\
\hline Yucca brevifolia & 5 & 2 & 29 \\
\hline
\end{tabular}

The herbaceous species, including the grasses Erioneuron pulchel7um, Oryzopsis hymenoides, and Stipa speciosa, and the herbs Sphaeralcea ambigua, Xylorhiza tortifolia, and Dyssodia cooperi probably germinated and grew largely in 1992 and 1993. They were killed by drought elsewhere on the NTS during 1989 and 1990 except on disturbed areas. Near the DAF the older disturbances were dominated in 1993 by the summer annual Eriogonum deflexum, and had not yet been invaded by the local herbaceous perennial species.

Continuing change can be expected in perennial vegetation near the DAF, as recovery from construction disturbance proceeds. Rates of recovery of perennial vegetation elsewhere on the NTS are very slow. On7y bunchgrasses and a rare shrub were present on ground zeroes from above-ground nuclear weapons tests thirty years after cessation of testing (Hunter 1994c, d). North-facing slopes of subsidence craters contained only recently germinated shrubs (Atriplex canescens) 23 and 24 years after they were created (Hunter in press $c$, d), although the south-facing slopes did not. 
If construction disturbances surrounding the DAF are not disturbed again during operation, gradual increases in grass and shrub populations can be expected. Perennial $\mathrm{plants}$ already rooted within about $10 \mathrm{~m}$ of these disturbances can be expected to grow to increased cover and volume, as they use water from the disturbed areas. Some new species can be expected in these more mesic areas, as was seen along the 5-05 road in Frenchman Flat in 1990 (Hunter 1994c). One species not seen on the 100 plots which should be expected is Hymenoclea salsola (white burrobrush). It is the primary shrub invading ground zeroes in Yucca Flat, and is also common on roadsides in Frenchman Flat. Germination of many shrub species appeared to be rare.

Predictable effects of DAF operations on perennial vegetation will be largely related to the disturbance regime. Scraping of roadsides and clearing of parking lots, clearing of vegetation growing on and around the DAF, traffic along dirt roads for maintenance of water and sewage facilities, and possibly for security purposes, will maintain certain areas in a constant state of disturbance. P7ants adjacent to these disturbances will grow larger, as along Mojave Desert roadsides in other areas (Johnson et a7. 1975; Lightfoot and Whitford 1991).

\section{SENSITIVE PLANTS}

A few sensitive plant species occur within several miles of the DAF. Camissonia mega7antha occurs in significant numbers at Cane Springs, on French Peak, and on the scraped roadside entering Area 11 (Plutonium Valley). Phacelia beat7eyae has been seen on loose, eroded volcanic soils on Skull Mountain and at the base of French Peak (Rhoads and Williams 1977). Cymopteris ripleyi saniculoides occurs occasionally in sandy soils in the center of Frenchman Flat. Arctomecon merriamij occurs in washes along the base of limestone hills forming the southern margin of Frenchman Flat (Spotted Range, Mercury Ridge). Habitats of these species are not found near the DAF, although some could colonize repeatedly disturbed areas such as roadsides, or subsoils bared by construction activity. The DAF is not expected to affect extant populations of these species in any way.

\section{REPTILES}

DAF reptile studies dealt with four topics: effect of the main DAF access road; differences between disturbed areas around DAF buildings and other local nondisturbed areas; effect of the diversion ditch around the DAF; and 
investigations of reptile species of special concern. The main consequence for Tizards of human disturbances at the DAF appears to be vegetational changes associated with site construction. The main vegetational change is removal of perennials as a consequence of grading for roads, building sites, or parking 1ots. Effects of vegetation on lizard distributions or abundances are wel1 known (see Pianka 1986, Vitt 1991 for a review). Vegetational characteristics can influence insect abundance and thus the lizard's prey base (Pol is and Yamashita 1991; Dunham 1980), or perch availability or temperature regimes available, and thus duration and effectiveness of prey capture or predator avoidance. Given this background, DAF construction activities were expected to influence lizards.

The main DAF road had no effects on weight, SVL, or age composition of sideblotched lizards, the most commonly encountered reptile on the NTS. The higher spring to summer recapture rate for side-blotched lizards on control plots relative to the roadside suggests either survival is higher or dispersal off the plot reduced, on the control relative to the roadside plots. The reduced number of perennials along the road could increase lizard mortality via increasing predation and thereby lower survival, or dispersal could be greater off roadside plots for this or some other factor. Transect or plot results did reveal sizeable road effects on lizard numbers. In spring, there were more side-blotched lizards in the control area than along the road (Fig. 9). By summer, sample numbers did not differ between roadside and control areas, implying road effects were seasonal (Fig. 9). A closer examination of roadside plots in spring ( $F i g .10$ ), reveals no side-blotched lizards near the road, but equivalent densities in the berm and control areas. By summer, graded or paved areas were still unoccupied by side-blotched 1izards, but, their densities on the berm had doubled, while those on the control area were unchanged from spring. The net effect was that by summer, berm areas had side-blotched lizard densities twice those of nearby control areas. The most likely explanation for this shift is that the greater number of females on the berm in the spring ( $150 \%$ of control levels) lead to greater reproduction there. Medica et a]. (1994) showed a very strong correlation across the NTS between number of females in spring and number of hatchlings in the summer. An alternative explanation is differential dispersal into the berm area. Only movement studies would allow us to eliminate this potential explanation. A final alternative is that the berm area may have contained more insects (see Lightfoot and Whitford 1991 for evidence) and that this lead to greater survival in this area. 
During the spring, whiptails had similar densities in the berm and control areas, but densities only 15 to 20 percent of those levels along the roadside. Distributions of whiptail and side-blotched lizards suggest effects within 10 $m$ of the road arise from vegetation removal due to paving or grading roadsides, as shrubs were considerably more abundant in the control area, or the second $10 \mathrm{~m}$ away from the road relative to the first $10 \mathrm{~m}$ away from the road. By summer the female biased sex ratio along the road had disappeared. Whether this change reflects a male biased clutch sex ratio or differential dispersal is not clear. BECAMP's roadside studies suggest the road had negative effects on side-blotched lizards and whiptails, two of the most prevalent lizards in western deserts (Pianka 1986).

Lizard populations in the DAF ditch also differed a great deal from nearby controls (Figures 10, 11). Control areas were dominated by side-blotched lizards (10 to 15 times ditch densities), while the ditch was dominated by zebra-tailed lizards (6 to 15 times control densities). Whiptail 1izards were also more abundant ( 7 to 39 times ditch densities) in the control area relative to the ditch. Pooling across species, control areas contained more lizards relative to the ditch. These differences are likely due to shrub removal and elimination of small mammal holes at the soil surface. Both of these activities remove cover for the lizards. Shrub removal also eliminates a resource base for insects, the lizards' primary prey base. Zebra-tailed lizards are known to favor open habitats (Pianka 1986), and thus have probably increased in the cleared ditch. Number of lizards per species, total number of lizard species, or total number of lizard individuals per plot differed between the DAF ditch and either the flat or the arroyo control areas, however, flat or arroyo control areas never differed. These results imply that either flat or arroyo areas may be used interchangeably as controls when testing for DAF effects on lizards.

Timed surveys were performed in 5 areas near the DAF (disturbed areas near DAF, area out to $1 \mathrm{~km} S$ of DAF, $N$ of DAF [about $1 \mathrm{~km}$ ] to the water tank, water tank to foothills, $0.2 \mathrm{~km}$ into foothi71s). Five investigators of various experience levels, ages, and physical abilities participated in these surveys. In spite of their differing abilities, counts/30 minutes did not vary across investigators, suggesting that investigators were largely interchangeable and that this variable had no effect on our number estimates. In contrast, there were sizeable differences in lizard numbers across areas (Figures $13-16$ ). Zebra-tailed 1izards were 6 to 18 times more abundant in graded areas around the DAF relative to all other areas. While no quantitative data were 
collected on densities in the ditch versus around the building, these lizards appeared dense in the ditch and essentially absent from other graded areas around the building. This may be because of the high soil compaction in most non-ditch areas or due to the gravel added to the surface of many of these areas. Side-blotched lizards were 8 to 10 times as abundant in the three sample areas north of the DAF relative to the disturbed area around the DAF buildings. Side-blotched lizard densities south of the DAF were indistinguishable from DAF densities. Whiptail densities were higher just north of the DAF relative to the area from the foothills back to the water tank, a17 other areas were indistinguishable. There were no differences across areas in number of species, however, the DAF area had more individual lizards (pooled across all lizard species) than the area south of the DAF. Again a 11 other areas were indistinguishable. These results suggest lizard densities are not uniform near the DAF. The disturbed areas around the DAF buildings and the road edges were largely devoid of lizards. In contrast, the DAF ditch appeared to contain high densities of zebra-tailed lizards.

Superimposed on this pattern, the area to the north of the DAF contained more individual lizards, while the area south of the DAF contained few lizards relative to other areas near the DAF.

\section{Potential Effects of the DAF on Reptiles}

With one field season now complete, the ecological consequences of DAF operation are becoming clear. DAF operation as an assembly facility is likely to release no or extremely small quantities of radioactive material during normal operations. Release would likely be windborne and occur in quantities too small to have measurable ecological impacts. Accidents could in principle release significant quantities of radioactive material with potentialiy deleterious ecological consequences. Physical operation and maintenance of the DAF facility is the most likely avenue for the DAF to effect plants and animals (Table 1). These effects are potentially major, long lasting, and may reach considerable distances from the DAF. A7so, because these factors emanate from the DAF buildings, their effects can potentially be confused with effects of an accident at the DAF. This has important ramifications for monitoring designs as it will influence abilities to separate nonnuclear (largely unregulated) and nuclear (regulated) effects of DAF operation. The potential ecological consequences of DAF operation are discussed in further detail under "Proposed Monitoring Efforts". 


\section{BIRDS}

Fifty-seven species of birds were recorded on habitats at or near the DAF in 1993. More than half of these (31) were migrants and the remainder were classified as summer or permanent residents (Appendix-D). Thirty-nine of these 57 species (68\%) were seen at the sewage pond: 18 species (32\%), were seen only on natural habitats. Three species (5\%) were seen around strictly disturbed habitats. Thirteen of 31 species (42\%) found in natural habitats were drawn to the pond. Some migratory birds typically attracted to water (e.g. long-billed curlew, killdeer) will also occupy other habitats for short periods. Therefore different habitats support or attract different species. A complete species area list requires sampling multiple habitats or microhabitats.

Bird usage of the sewage pond was considerable during summer months. Use changed over time with peak usage exceeding 700 bird visits per hour in early June. The most numerous species, mourning doves and house finches raised broods during the summer, when drinking was common at the ponds. These species probably benefited from having access to water when water would normally be lacking. Many species that migrate seasonally also benefited from the ponds. For instance, sage sparrows drank heavily in the fall using habitats at the DAF for winter range. Other common groups of birds such as ducks, sandpipers and avocets regularly stop to rest and forage during migration. Juvenile black-throated sparrows drank heavily from the ponds during July possibly increasing survival of many local fledglings.

Comparisons of density of adult black-throated sparrows on plots away from to those near the pond showed no difference. It suggests increased avian activity near the pond may not have displaced adult songbirds from natural habitats nearby. This is stated with caution because limited sampling occurred on plots near the pond. However, large numbers of birds surrounding the pond in May-June could have reduced local breeding attempts by adult songbirds because of constant interference. Similarly, breeding success could have been reduced by increased predation. This was not investigated in 1993 .

While densities could not be estimated for all species, counts on Plot 1 in spring-summer (Table 19) suggested differences in relative bird abundances in natural habitat (house finch < mourning doves < black-throated sparrows). Actual densities between species may vary as relative abundance shown above. However, lower densities of doves and finches near the DAF area as compared to 
black-throated sparrows may be a reflection of greater daily dispersal distances. Furthermore, both doves and finches drank from the pond during the breeding season, requiring daily movements, while black-throated sparrows did not. Doves are known to migrate distances up to 1-8 km daily (Losito and Mirarchi 1991). Consistent with this, observations with binoculars at the DAF sewage pond indicated doves as well as finches appeared to fly moderate distances away $(>1 \mathrm{~km})$ after pond visits. Breeding birds dependant on summer water may disperse from a heavily used water source to avoid large numbers of birds (drawing predators) or other negative impacts on nesting success.

Birds are particularly difficult to study because of their general mobility, migratory habits, and low densities. Effects of the sewage pond are complex because perceived benefits to some species (leading to population increase) could potentially cause negative impacts on others. This could occur through competition for limited food resources or space.

Disturbed (bladed) areas at the DAF may reduce area for most native species but may also create habitat for those preferring open areas (e.g. horned lark, water pipit). Annual plants growing abundantly on roadsides and bladed areas may bear considerable seed for bird species to consume conferring a benefit. For example, house finches and sage sparrows consumed seeds of Salsola australis and Eriogonum deflexum growing along denuded areas on dirt roads and near the sewage pond. Detailed work on bladed areas near the DAF buildings or on roadsides was not performed in 1993.

Birds seen only at the sewage ponds and the DAF building included ravens, barn owls, European starlings and house sparrows (the latter two introduced). Starlings and house sparrows are aggressive cavity nesters that form large flocks when abundant and have been implicated in the demise of cavity nesting species such as eastern bluebirds, northern flickers, and swallows. (Ehrlich et a1. 1988, Ryser 1985). They usual7y become common in desert areas after buildings are constructed, in part from the creation of additional nesting habitat. When abundant these species may have negative impacts on resident cavity nesters such as Say's phoebe and ash-throated flycatcher.

Brown-headed cowbirds were also observed at the sewage ponds. This species is an obligate nest parasite which ejects eggs of other species replacing them with its own. It has been implicated in the demise of North American songbirds (Bohning-Gaese et a1. 1993). This species would be of concern if it were to become abundant. 
Large numbers of doves at the sewage pond attracted predators such as coyote, owls, hawks, falcons, and ravens, all of which could benefit from increased abundance of food. Increased numbers of predator/scavengers such as coyotes and ravens could potentially impact tortoise populations by feeding on young (Luckenbach 1982, Berry 1986). Raptors may be attracted to the DAF buildings because they offer perch sites, insects or other prey, and potential nest sites. Windows on guard towers and light poles, may be hazardous to migrating raptors because of col1isions causing mortality. Indirect affects of litter from human activity (dumpsters) can provide food for many species. Raptors or ravens can be drawn to prey attracted to buildings, roadsides, or cleared areas, resulting in collisions with vehicles or structures.

While many of the potential effects of DAF activities on birds are subtle, they should not be considered unimportant. The greatest potential impact is from the sewage pond because many different species may be affected although on a scale of only a few miles distant. Clearing of shrubs is severe for a77 biota because it removes habitat and changes species distributions. Mitigations should favor minimizing total area cleared during future operations.

\section{MAMMALS}

Species number and abundance on the DAF traplines most resembled that in the Mojave Desert mosaic of the NTS (see Hunter and Medica 1989; Saethre and Medica 1992; Saethre 1994). This is based mainly on the near absence of Dipodomys microps at the three sites. The Tow number of Perognathus longimembris was not usual for a site in Frenchman Flat, as sites trapped in this area have shown reduced numbers during the 1 ast 5 years. The large proportion of Chaetodipus formosus does deviate from the normal trapping results in Frenchman Flat. This species was previously captured in high numbers only on the southern end of the NTS in Mercury and Rock Valleys (French et a1. 1966, 1967; Turner 1973, 1975; Turner and McBrayer 1974; Saethre and Medica 1992; Saethre 1994).

In the Mojave Desert, available ephemeral plant material generally depends on adequate amounts of winter rainfall for germination and spring rain for growth (Beatley 1974b, 1976; Bowers 1987). Most rodents are herbivores or granivores and depend on adequate quantities of plant biomass (most importantly from annual plants) for reproduction and growth (Kenagy 1972, 1973; Van de Graaff and Balda 1973; Reichman and Van de Graaff 1973, 1975; Kenagy and Bartholomew 
1981). Consequently 1993, a year of ample rainfa11, was a year of high rodent abundance. The copious number of rodents in 1993 may explain why DAF monitoring did not show any anomalies in rodent abundance or diversity between sites. No real conclusions should be made on mean weight differences between sites sampled over time with so few samples, although some effect of the road was evident.

\section{Trap Type}

The effectiveness of the mesh traps is questionable. 0'Farrell et a1. (1992) captured over twice as many individuals of three species in mesh traps when sequentially trapping with mesh and Sherman live traps. At the DAF site only one species was captured more often in the mesh traps, suggesting that it may not be worth the added hassle of baiting the extra-sensitive traps. The high number of torpid rodents and potential mortality was also not acceptable. Using cotton batting would reduce the number of hypothermic rodents, but also requires more effort and causes a pollution problem.

Animal abundance at the DAF sites appeared to be high relative to historical norms at the NTS. This may have negated any benefit from the mesh traps due to saturating traps with captures. Both traps at a station contained animals on 168 occasions in early June. Species diversity was slightly higher for Sherman traps (Table 25), and, overa11, the results were not compel1ing enough to switch exclusively to mesh traps.

\section{PROPOSED MONITORING EFFORTS}

BECAMP's monitoring program is intended to assess both nuclear and nonnuclear (Table 1) consequences of DAF operation. Preoperational sampling in 1993 revealed several gradients in species abundances in the DAF vicinity which were incorporated into the monitoring program. Monitoring programs are discussed with respect to each group of study organisms.

\section{EXPECTED DAF EFFECTS AND FUTURE MONITORING OF EPHEMERALS}

Construction disturbance currently surrounds the DAF, and is already having major effects on the ephemeral $\mathrm{plant}$ populations. In the absence of further disturbance, one would expect an increase in weedy and introduced species on and near present disturbances, and a very gradual recovery over a period of many decades. (The ground zeroes and subsidence craters in Yucca Flat show 
only the beginnings of normal plant populations some 30 to 35 years after disturbance - Hunter 1994a, b).

Continuing disturbance can be expected near the DAF for road maintenance, clearing of parking and traffic areas, runoff events reestablishing blocked drainage channels and new ones created by the dike, and clearing of vegetation to maintain visibility for security purposes. These conditions favor the maintenance and spread of weedy introduced species, which are causing significant ecological changes worldwide (e.g., Holzapfel et al. 1992; Pavlik et al. 1993; Tyser and Worley 1992).

Besides effects of DAF operation and recovery from the construction disturbance, ephemeral populations on the NTS are faced with effects of the many introduced species now present, with changes in soil fertility associated with air pollution, and with human-caused and natural climate change. Given these threats, ephemeral species diversity is expected to decrease, especially among those species already present in low numbers or in small disjunct patches.

Future monitoring of ephemeral plants near the DAF should allow an assessment of how DAF operations affect the balance between rare native and weedy introduced species. The extent of continuing disturbance should be monitored, as well as the distance from disturbance to which introduced/weedy species spread. The presence and densities of rare species in undisturbed habitat near the DAF should be monitored, as should the association of the weedy species with various DAF-related disturbances. These monitoring efforts will require further method development.

There are several possible ways to organize future monitoring of ephemerals. The first would be to monitor random locations around the DAF to detect changes generally associated with the DAF. Another would be to focus on particular disturbances and design monitoring to detect particular variables, such as distance of spread of weedy plants away from the roadside or disturbed areas, to monitor plant populations on particular kinds of disturbance, and to monitor $\mathrm{plant}$ growth, reproduction, and species composition at significant distances from disturbance. The latter would do a better job of determining expected effects, while the former might have a better chance of detecting unexpected effects. The latter would also provide precise information on specific questions, while the former would provide general information for many questions. We believe that for ephemeral plants more specific monitoring 
would be of greater value per effort expended. Current methods for monitoring ephemerals are too time consuming and statistically inadequate to detect unanticipated or subtle changes.

Our recommendation is to use BECAMP's standard technique to determine ephemeral plant population parameters on the paved roadside, a scraped and graveled area, a scraped/compacted area, and two or three control areas. The control areas should be several hundred meters from the nearest disturbance, which would require sites at least a kilometer from the DAF. In addition, the $\log _{10}$ technique should be used to monitor the spread of weedy species away from an example of each of the three disturbance types studied. Finally, the extent of continuing disturbance should be monitored to help distinguish operational from construction effects and allow management to exercise some control over the disturbance/recovery processes near the DAF.

Data collection for the proposed monitoring would take two to four man weeks between April 1 and May 1. Analysis and reporting would take considerably longer. If time or funding is not adequate, the effort should be reduced by cutting out disturbance and control sites proportionately.

\section{PERENNIAL PLANTS}

Perennial plant parameters amenable to monitoring include germination and establishment of seedlings (population changes), growth and dieback of established plants, and reproduction and grazing of established plants. Different species exhibit different habits, and differ somewhat in speed of response to disturbance. The herbaceous perennials, for example, reproduce quickly and are generally short-lived, while the long-lived dominant species generally grow and die back with few changes in number. In general, however, perennial plants change rapidly by growth and dieback, and more slowly and erratically by germination, establishment, and death of whole plants.

Predictable effects of DAF construction on perennial plant populations include increased growth of plants near disturbances (an effect of reduced competition for water), increases in weedy herbaceous perennials on and adjacent to disturbed areas, and increases in grazing damage associated with rabbits (which preferentially graze on the moister vegetation on disturbed areas, (Hunter 1987). Changes over wide areas or changes in species composition, such as might occur with plants, are unlikely. Because expected changes are minor, and there are no predicted effects of DAF operations, we believe 
perennial sampling should be aimed at detecting unpredicted changes and perhaps changes in radionuclide contents.

Plant transects set up in 1993 should be monitored each year both near and far from the DAF. Because relatively few perennial plants are present in each plot, we recommend sampling a 71100 plots each year. Censusing these plots provides information on the fult range of species present at the DAF, and would allow determination of year-to-year changes in size, populations of herbaceous species, reproduction, and grazing patterns. It would put monitoring personnel in all areas surrounding the DAF, and thus provide opportunities to observe unexpected patches of dying plants or other unusual occurrences.

Monitoring involves observing a site and reporting unfavorable trends or occurrences to management, who then modify procedures and/or goals accordingly. To satisfy this need to warn management, it is important to monitor perennial plants on an annual basis, even in the desert where change is sometimes slow. Monitoring desert biota on a multi-year frequency does not provide timely warnings. It also would miss data on when changes occur, which would allow determination of causes of unpredicted change. Monitoring more frequently than annually would lead to tracking changes associated with reproductive and growing seasons, which would greatly complicate data collection and interpretation.

We recommend sampling the marked Ephedra nevadensis, Yucca brevifolia, and Larrea tridentata nearest the 100 plots on a three-year frequency. These species are long-lived and slow-growing, they are mostly large and therefore not fragile, and they tolerate weather extremes better than most species. These stable species are less likely to respond rapidly to changes associated with DAF operations, and their monitoring is therefore less urgent.

Certain operations are expected, such as roadside maintenance and clearing of vegetation in parking and vehicle access areas. Most DAF-related damage to the perennial plant ecology of the surrounding area is caused by clearing that occurred during construction. We recommend that these disturbed areas be monitored for continuing disturbance, to document interference with recovery processes. A number of $\mathrm{plant}$ transects are already in these cleared areas, but additional plots specially placed to document recovery processes may be desirable. A decision on monitoring efforts for these areas should be made after construction activities are completed. 
Monitoring at the suggested levels (Table 29) would require approximately two man-months of field work during summer, most7y by college students, plus an equivalent time spent analyzing and reporting data by senior personnel. An additional man-month would be necessary every third year when remeasuring the marked individuals of the dominant species.

\section{SENSITIVE PLANTS}

No endangered, threatened, or candidate $\mathrm{plant}$ species was seen during baseline characterization studies, nor was any habitat suitable for those species seen. Therefore, no activities are planned specifically to characterize sensitive plant species. If such species are seen during future monitoring efforts, their presence will be noted and monitoring plans may be revised accordingly.

\section{REPTILES}

Reptile abundances were greater in nondisturbed areas away from the DAF relative to the disturbed areas near it, implying negative consequences for reptiles of nonnuclear human activities associated with the DAF. The main access road also appeared to negatively affect lizards. Finally, there was evidence that nondisturbed areas north of the DAF contained more lizards than nondisturbed areas to the south, suggesting the lizard fauna may not have been homogeneous in this area prior to DAF construction. This means designation of an appropriate control area for the DAF building complex is problematic.

Given these preliminary findings, three types of reptile monitoring are proposed (Table 29). The first is a series of transects in the disturbed area around the DAF, and radiating away from it. This protocol is designed to assess effects of operation of the DAF buildings. Transects consist of $100 \mathrm{x}$ $15 \mathrm{~m}$ wide sections isolated from one another by $100 \mathrm{~m}$. These transects are located on four sides (the cardinal directions) of the DAF disturbed area. Each quadrant contains 2 transect sections in the disturbed area, and four radiating out from it. Lizard counts within each $100 \mathrm{~m}$ section will be made following standard BECAMP techniques (Medica et a1. 1994; REECO Tizard study procedure AABAF.D.05.00 revision 1, revised 28 Aug. 1991). Each transect wi11 be walked four times. Two analyses will be performed on these counts. A three-way analysis of variance test, with direction (north, south, east, west) day sampled, and location (in disturbed areas vs nearest two vs farthest two sections in undisturbed habitat) will be used to contrast lizard numbers in the area of immediate DAF operations to more distant areas. This analys is is 


\begin{tabular}{|c|c|c|c|c|}
\hline \multicolumn{5}{|c|}{$\begin{array}{l}\text { Table 29. Field manpower needs for proposed DAF monitoring } \mathrm{plan} \text {. Data entry, analysis and report writing } \\
\text { are estimated to take } 100 \% \text { of field time, and should be added to the field time to get total manpower } \\
\text { needs. }\end{array}$} \\
\hline 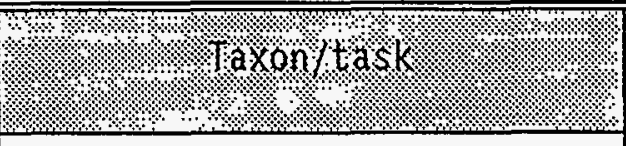 & 4 Manpower stat? & 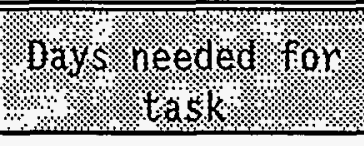 & T: & 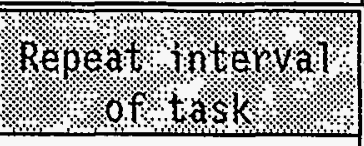 \\
\hline $\begin{array}{l}\text { Reptiles/ Walking transects } \\
\text { radiating from DAF }\end{array}$ & $1(2)$ & $\begin{array}{l}4 \text { days } \times \text { two } \\
\text { seasons }=8\end{array}$ & 24 & every year \\
\hline $\begin{array}{l}\text { Reptiles/ Walking plots in } \\
\text { disturbed and undisturbed } \\
\text { areas near the DAF }\end{array}$ & $1(3)$ & $\begin{array}{l}5 \text { days } \times \text { two } \\
\text { seasons }=10\end{array}$ & 40 & $\begin{array}{c}\text { once every } 3 \\
\text { years }\end{array}$ \\
\hline $\begin{array}{l}\text { Reptiles/ Walking plots in } \\
\text { roadside and control area }\end{array}$ & $1(3)$ & $\begin{array}{l}5 \text { days } \times \text { two } \\
\text { seasons }=10 \\
\end{array}$ & 40 & $\begin{array}{c}\text { once every } 5 \\
\text { years }\end{array}$ \\
\hline $\begin{array}{l}\text { Reptiles/ General survey for } \\
\text { chuckwalla and desert } \\
\text { tortoise }\end{array}$ & $1(2)$ & 5 days & 15 & every year \\
\hline Ephemeral plant censusing & $1(0)$ & 6 days & 6 & every year \\
\hline Perennial plant plots & $0(2)$ & 20 days & 40 & every year \\
\hline Marked perennials & $1(2)$ & 5 days & 15 & every 3 years \\
\hline Raven count at sewage pond & $1(0)$ & 8 days & 8 & every year \\
\hline Birds/ Census circular plots & $1(0)$ & 5 days & 5 & alternate years \\
\hline Birds/ Nest searches & $1(1)$ & 15 days & 30 & alternate years \\
\hline Birds/ Disturbed areas & $1(0)$ & $\begin{array}{l}5 \text { days } x \text { two } \\
\text { seasons }\end{array}$ & 10 & $\begin{array}{c}\text { once every } 3 \\
\text { years }\end{array}$ \\
\hline
\end{tabular}




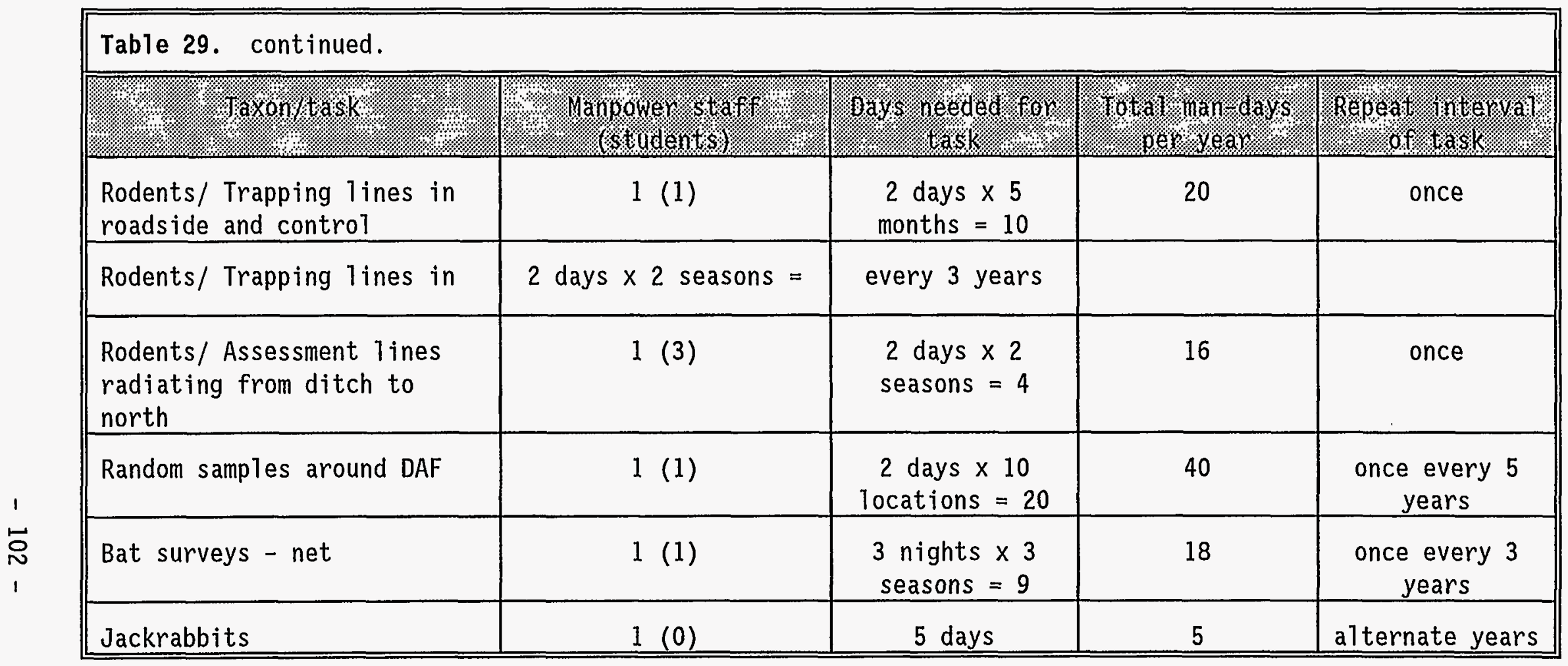


designed to assess overall effects (both nuclear and nonnuclear) of DAF operation on lizards. The other analysis is a regression examining variation in lizard numbers as a function of distance from the DAF disturbed areas. This analysis is designed to assess long distance effects of the DAF which we suspect would be mainly nuclear, should a mishap occur. Both sampling protocols incorporate directional faunal differences into the analysis. The field work for this monitoring program requires three people for four days and should be performed annually, as these data would be essential for interpreting the consequences of a nuclear mishap on lizards.

The second monitoring program involves a modified mark-recapture program (Medica et a1. in press). This approach yields a better estimate of sideblotched-1izard numbers than the transect technique discussed above. The technique is, however, much more labor intensive (four people for five days to sample a much smaller area), and will be used only every three years. Sampling in the undisturbed area will be restricted to two arms (north and south or east and west in alternating sampling periods) of the transect array in any sample year. Lizard numbers will be estimated in the eight transect sections in undisturbed habitat and compared to the eight transect sections in the disturbed area with an analysis of variance. This study enables us to examine DAF effects on side-blotched lizards more closely, and will be used to calibrate transect-study-results.

The final lizard monitoring program will be to repeat the roadside studies protocol discussed in this report, once every five years. This will allow us to examine continuing effects of the road on lizard numbers.

Two species of special concern, the desert tortoise and the chuckwalla, occurred near the DAF. The status of these species will be assessed with general opportunistic surveys over 15 man days in each year. These surveys will be modeled after the timed surveys discussed in this report.

\section{BIRDS}

Recommended future work (Table 29) includes counting ravens at the sewage pond with current methods ( 1 hour counts) yearly to assess potential long term increases. From February to December all bird species present at the sewage pond wil7 be recorded to continue development of a species list for the DAF. Circular bird plots will be resampled to obtain baseline density estimates on 
natural areas and near the sewage pond in the second year and every other year thereafter using variable circular plot techniques.

Nest site searches will be performed near the sewage pond and compared to natural areas to assess pond impacts on local breeding success. Two plots (10-15 ha) near the sewage pond and two about 600-800 meters away will be marked with stakes at $50 \mathrm{~m}$ intervals. Plots will be searched for nests from Apri1-June. Individual nests will be examined for eggs and nest1ings, and comparisons made across plots to examine treatment effects.

Relative abundance of birds on bladed areas near DAF or roadsides may be compared to those in a natural habitat using 9 minute counts at various stations ( 2 minute rest period) along a transect. Transect length $(300-700 \mathrm{~m})$ and number of stations (3-6) placed about $100 \mathrm{~m}$ apart could vary depending on shape or length of disturbed area. Birds will be counted within a $20 \mathrm{~m}$ wide band perpendicular to the transect and within $40 \mathrm{~m}$ along the transect (McGarical and McComb 1992). Breeding activity of birds associated with the buildings and bladed areas will be recorded. Finally, DAF lights will be examined at night to determine bird attraction, and to record presence of any dead or injured birds.

General observations and records of loggerhead shrikes and other sensitive species will be made at the DAF and in the immediate vicinity as part of the monitoring effort.

\section{MAMMALS}

To determine the precise timing of reproduction in rodents around the DAF, trapping at shorter intervals is needed. Since reproduction in rodents is clearly related to weather patterns (i.e., rainfall producing vegetation for forage) this question can probably not be answered by trapping at three year intervals. As such, one year of trapping on a monthly basis will be done to corroborate 1993 results. Future effort will emphasize abundance and diversity of disturbed areas in comparison to relatively natural areas (Table 29).

Fine tuning of species distribution and abundance will be accomplished by trapping shorter lines or grids at several distances from the DAF. Snap traps or pitfalls may also be used in selected areas. Approximately 20 such 
locations can be set up with a minimum effort and sampled on a five year basis.

Assessment lines from the disturbed area near the drainage dike and crossing FRF011 may help determine to what extent the ditch is a barrier to dispersal and how it may affect rodent abundance (Table 1). Other specific disturbances to be assayed in the future may include the attraction of the lights to bat species, the spotted bat in particular. This may entail using nets and possibly digital audio tape recorders. The other disturbances listed in Table 1 are less likely to have any ongoing impact on the small mammal population. The mobile rodents will have no trouble passing through the chain- 7 ink fence to the cleared area. However, this area is so depauperate in vegetation that foraging is not likely and any feeding or dispersing rodent would be exposed to an increased risk of predation.

Use of two traps wi7l be continued based on the high trap success at this site. The two different trap types will continue to be used on a trial basis in case poorer quality years show differences in trap preference. Trapping sessions will be limited to two days and performed once a month in 1994 during peak rodent activity (April through September). New captures decreased markedly after the second morning in 1993, suggesting a third day would only deliver marginaliy better data for the added effort in future years (Table 29). This would considerably reduce the manpower needs and facilitate trapping at more locations around the DAF.

After one more year of intense study, monitoring on a smaller scale (one session each in spring and summer) will continue on a three-year cycle, possibly with even shorter assays in the other two years. Future monitoring will require less effort once all plots are set up (Table 29). Concentrating on abundance and diversity will yield relatively clear results at low manpower cost. Relative abundance of jackrabbits can be monitored for several days each month. An observer will count rabbits per hour in undisturbed habitat recording number of juveniles and adults, and noting condition and presence of any dead animals away from the roads. 


\section{REFERENCES}

Allred, D.M. and DE. Beck. 1963. Ecological distribution of some rodents at the Nevada Atomic Test Site. Ecology 44:211-214.

ATTred, D.M., DE. Beck, and C.D. Jorgensen. 1963. Biotic communities of the Nevada Test Site. Brigham Young University Science Bulletin Biological Series 2:1-52.

Banks, R.C., R.W. McDiarmid and A.L. Gardner. 1987. Check1 ist of Vertebrates of the United States, the U.S. Territories and Canada. U.S. Fish Wild1 ife Serv., Resour. Publ. 166. 79 pp.

Beatley, J.C. 1974a. Effects of rainfall and temperature on the distribution and behavior of Larrea tridentata (creosote bush) in the Mojave Desert of Nevada. Ecology 55:245-261.

Beatley, J.C. 1974b. Phenological events and their environmental triggers in Mojave Desert ecosystems. Ecology 55:856-863.

Beatley, J.C. 1975. Climates and vegetation pattern across the Mojave/Great Basin Desert transition of Southern Nevada. Amer. Mid1. Natur. 93:53-70.

Beatley, J.C. 1976. Vascular plants of the Nevada Test Site and CentralSouthern Nevada: ecologic and geographic distributions. Report TID-26881, NTIS, U. S. Department of Commerce, Springfield, VA 22161. $308 \mathrm{pp}$.

Beatley, J.C. 1979. Shrub and tree data for plant associations across the Mojave/Great Basin transition of the Nevada Test Site, 19631975. Report DOE/EV/2307-15, NTIS, U. S. Dept. of Commerce, 5285Port Royal Rd., Springfield, VA 22161. 52 pp.

Berry, K.H. 1986. Desert tortoise (Gopherus agassizij) research in California 1976-1985. Herpetologica 42:62-67.

Bohning-Gaese, K., M.L. Taper and J.H. Brown. 1993. Are declines in North American insectivorous songbirds due to causes on the breeding range? Conservation Biology 7:76-86.

Bowers, M.A. 1987. Precipitation and the relative abundance of desert winter annuals: a 6-year study in the northern Mohave Desert. $\mathrm{J}$. Arid Environ. 12:141-150. 
Bradley, W.G. and R.H. Mauer. 1971. Reproduction and food habits of Merriam's kangaroo rat, Dipodomys merriami. J. Mammal. 52:497-507.

Bradley, W.G. and K.S. Moor. 1975. Ecological studies of small vertebrates in Pu-contaminated study areas of NTS and TTR. pp. 151-185 In: The Radioecology of Plutonium and Other Transuranics in Desert Environments. Nevada Applied Ecology Group Progress Report as of January 1975. M.G. White and P.B. Dunaway, eds. NAEG/ERDA Report NVO-153, NTIS, U.S. Department of Commerce, 5285 Port Royal Road, Springfield, VA 22161. $503 \mathrm{pp}$.

Bradley, W.G. and K.S. Moor. 1976. Ecological studies of small vertebrates in Pu-contaminated study areas of Nevada Test Site and Tonopah Test Range. pp. 53-65 In: Studies of Environmental Plutonium and Other Transuranics in Desert Ecosystems. M.G. White and P.B. Dunaway, eds. NAEG/ERDA Report NVO-159, NTIS, U.S. Department of Commerce, 5285 Port Royal Road, Springfield, VA 22161. $189 \mathrm{pp.}$

Bradley, W.G. and K.S. Moor. 1978. Ecological studies of small mammals in a nuclear site on the Nevada Test Site. pp. 1-13 In: Selected Environmental Plutonium Research Reports of the NAEG. M.G. White and P.B. Dunaway, eds. NAEG/DOE Report NV0-192, NTIS, U.S. Department of Commerce, 5285 Port Royal Road, Springfield, VA 22161. 318 pp.

Bradley, W.G., K.S. Moor, and S.R. Naegle. 1977a. P7utonium and other transuranics in smal1 vertebrates: a review. pp. 385-405 In: Transuranics in Natural Environments. M.G. White and P.B. Dunaway, eds. NAEG/ERDA Report NVO-178, NTIS, U.S. Department of Commerce, 5285 Port Royal Road, Springfield, VA 22161. 710 pp.

Bradley, W.G., K.S. Moor, and S.R. Naegle. 1977b. Plutonium concentrations and $\mathrm{Pu} / \mathrm{Am}$ ratios in smal1 vertebrates from NAEG study areas of NTS. pp. 207-219 In: Transuranics in Desert Ecosystems. M.G. White, P.B. Dunaway, and D.L. Wireman, eds. NAEG/DOE Report NVO-181, NTIS, U.S. Department of Commerce, 5285 Port Royal Road, Springfield, VA 22161. $469 \mathrm{pp}$.

Campbe11, H.W. and S.P. Christman 1982. The herpetological components of Florida sandhi11 and sand pine scrub associations. pp. 163-172 In: Herpetological Communities, N.J. Scott, Jr. ed., U.S. Dept. of the Interior, Fish and Wildlife Service, Wildlife Research Report 13. Washington, D.C. $239 \mathrm{pp}$. 
Casteller, R.C. and H.O. Hi11. 1979. Additions to the birds of the Nevada Test Site. Western Birds 10:221-223.

Chew, R.M. 1975. Effects of density on the population dynamics of Perognathus formosus and its relationships within a desert ecosystem. U.S./International Biological Program (IBP) Desert Biome Research Memo RM 75-18. Utah State Univ., Logan, UT. pp. 19-26.

Dingman, R.E. 1975. Interaction between a fossorial rodent (the pocket gopher, Thomomys bottae) and a desert plant community. U.S./IBP Desert Biome Research Memo RM 75-23. Utah State Univ., Logan, UT. pp. 50-57.

Dunham, A. 1980. An experimental study of interspecific competition between the iguanid lizards Sceloporus merriami and Urosaurus ornatus. Ecol. Monogr. 50:309-330.

EG\&G/EM (EG\&G Energy Measurements, Inc.). 1992. Yucca Mountain Biological Resources Monitoring Program Annual Report FY 91. EG\&G/EM Santa Barbara Operations Report No. 10617-2127, NTIS, U.S. Department of Commerce, 5285 Port Royal Road, Springfield, VA 22161. 68 pp.

EG\&G/EM. 1993. Yucca Mountain Biological Resources Monitoring Program Annual Report FY 92. EG\&G/EM Santa Barbara Operations Report No. 10617-2195, NTIS, U.S. Department of Commerce, 5285 Port Royal Road, Springfield, VA 22161. $77 \mathrm{pp}$.

Ehrlich, P.R., D.S. Dodkin, and D. Wheye. 1988. The Birders Handbook: A field guide to the natural history of North American birds. Simon and Schuster Inc., New York. 785 pp.

French, N.R. 1964. Description of a study of ecological effects on a desert area from chronic exposure to low level ionizing radiation. U.S. Atomic Energy Commission Report UCLA 12-532. 27 pp. + figures.

French, N.R., B.G. Maza, and A.P. Aschwanden. 1966. Periodicity of desert rodent activity. Science 154:1194-1195.

French, N.R., B.G. Maza, and A.P. Aschwanden. 1967. Life spans of Dipodomys and Perognathus in the Mojave Desert. J. Mamma1. 52:497-507.

French, N.R., B.G. Maza, H.O. Hi11, A.P. Aschwanden, and H.W. Kaaz. 1974. A population study of irradiated rodents. Ecol. Monographs 44:45-72. 
French, N.R., T.Y. Tagami, and P. Hayden. 1968. Dispersal in a population of desert rodents. J. Mammal. 49:272-280.

Hall, E.R. 1981. The Mammals of North America. New York, NY: John Wiley and Sons. Second Edition. 1181 pp. + Indices.

Hayward, C.L., M.L. Killpack and G.L. Richards. 1963. Birds of the Nevada Test Site. Brigham Young University, Sci. Bul1., Biol. Ser. $1: 1-27$.

Holzapfe1, C., W. Schmidt, and A. Shmida. 1992. Effects of Human-Caused Disturbances on the Flora Along a Mediterranean-Desert Gradient. Flora 186:261-270.

Hunter, R.B. 1987. Jackrabbit-shrub interactions in the Mojave Desert. Proceedings, Symposium on Plant-Herbivore Interactions. USDA Forest Service Gen. Tech. Rep. INT-222:88-92.

Hunter, R.B. 1991. Bromus invasions on the Nevada Test Site: present status of $B$. rubens and $B$. tectorum with notes on their relationship to disturbance and altitude. Great Basin Naturalist $51: 176-182$.

Hunter, R.B. Compiler. 1992a. Status of the Flora and Fauna of the Nevada Test Site, 1988. Report DOE/NV/10630-29. NTIS, U.S. Department of Commerce, 5285 Port Royal Road, Springfield, VA 22161. 229 pp.

Hunter, R.B. 1992b. Status of perennial plants on the Nevada Test Site in 1988. Pp. 183-228 In: Status of the Flora and Fauna on the Nevada Test Site, 1988. R. Hunter, compiler, Report DOE/NV/1063029, NTIS, U.S. Department of Commerce, 5285 Port Royal Road, Springfield, VA 22161. $229 \mathrm{pp}$.

Hunter, R.B. 1994a. Trends in ephemeral plant populations on the Nevada Test Site, 1989 - 1991. pp. $334-377+$ app. In: Status of the Flora and Fauna on the Nevada Test Site, 1989 - 1991. R. Hunter, compiler, Report DOE/NV/14432-57, NTIS, U.S. Department of Commerce, 5285 Port Roya7 Road, Springfield, VA 22161. 377 pp. + apps. 
Hunter, R.B. 1994b. Status of ephemeral plants on the Nevada Test Site, 1992. pp. $1-30$ + apps. In: Status of the Flora and Fauna on the Nevada Test Site, 1992. R. Hunter, compiler, Report DOE/NV/11432-58, NTIS, U.S. Department of Commerce, 5285 Port Royal Road, Springfield, VA 22161. 207 pp. + appendices.

Hunter, R.B. 1994c. Trends in perennial plant populations on the Nevada Test Site - 1989-1991. pp. 236 - 333 + apps. In: Status of the Flora and Fauna on the Nevada Test Site, 1989 - 1991. R. Hunter, compiler, Report DOE/NV/14432-57, NTIS, U.S. Department of Commerce, 5285 Port Royal Road, Springfield, VA 22161. 377 pp. + apps.

Hunter, R.B. 1994d. Status of perennial plants on the Nevada Test Site, 1992. pp. $176-207+$ apps. In: Status of the Flora and Fauna on the Nevada Test Site, 1992. R. Hunter, compiler, Report DOE/NV/14432-58, NTIS, U.S. Department of Commerce, 5285 Port Royal Road, Springfield, VA 22161. 207 pp. + apps.

Hunter, R.B., F.B. Turner, R.G. Lindberg, and K. B. Hunter. 1987. Effects of 7 and clearing on bordering winter annual populations in the Mohave Desert. Great Basin Natural ist 47:234-238.

Hunter, R.B. and P.A. Medica. 1989. Status of the Flora and Fauna of the Nevada Test Site: Results of Continuing Basic Environmental Research January through December 1987. Report DOE/NV/10630-2, NTIS, U.S. Department of Commerce, 5285 Port Royal Road, Springfield, VA 22161. $103 \mathrm{pp}$.

Inouye, R.S. 1991. Population biology of desert annual plants. Pp. 27-54 In: The Ecology of Desert Communities. G. Polis, ed. Univ. of

Johnson, H.B., F.C. Vasek, and T.Yonkers. 1975. Productivity, diversity and stability relationships in Mojave Desert roadside vegetation. Bulletin of the Torrey Botanical C7ub 102:106-115.

Jorgensen, C.D. and C.L. Hayward. 1965. Mammals of the Nevada Test Site. BYU Sci. Bul7. Biol. Ser. 6:1-81.

Kartesz, J.T. and R. Kartesz. 1980. A Synonymized Checklist of the Vascular Flora of the United States, Canada, and Greenland. Univ. of North Carolina Press, Chapel Hi17, NC. 500 pp. 
Kenagy, G.J. 1972. Saltbush 1eaves: excision of hypersaline tissue by a kangaroo rat. Science 178:1094-1096.

Kenagy, G.J. 1973. DaiTy and seasonal patterns of activity and energetics in a heteromyid rodent community. Ecology 53:1201-1219.

Kenagy, G.J and G.A. Bartholomew. 1981. Effects of day Tength, temperature, and green food on testicular development on a desert pocket mouse, Perognathus formosus. Physiol. Zool. 54:62-73.

Lightfoot, D.C. and W.G. Whitford. 1991. Productivity of creosotebush foliage and associated canopy arthropods along a desert roadside. Amer. Mid1. Natur. 125:310-322.

Losito, M.P., R.E. Mirarchi. 1991. Summertime habitat use and movements of hatchling-year mourning doves in northern A7abama. J. Wildl. Manage. 55:137-146.

Luckenbach, R.A. 1982. Ecology and management of the desert tortoise (Gopherus agassizii) in California. Pp. 1-37 In: North American Tortoises: Conservation and Ecology, R.B. Bury, ed. U.S. Dept. of Interior, Fish and Wildlife Service Wildlife Research Report 12. Washington, D.C.

Maza, B.G., N.R. French, and A.P. Aschwanden. 1973. Home range dynamics in a population of heteromyid rodents. J. Mamma1. 54:405-425.

McAuliffe, J.R. 1990. A rapid survey method for the estimation of density and cover in desert plant communities. J. Vegetation Science 1:653-656.

McGarigal, K., and W.C. McComb. 1992. Streamside verses ups7ope breeding bird communities in central Oregon coast range. J. Wildl. Manage. $56: 10-23$.

Medica, P.A. 1990. Noteworthy mammal distribution records for the Nevada Test Site. Great Basin Nat. 50:83-84.

Medica, P.A., M.B. Saethre, R.B. Hunter and J.D. Drumm. 1994. Trends in reptile populations on the Nevada Test Site. pp. $1-49+$ apps. In: Status of the Flora and Fauna on the Nevada Test Site, 19891991. R. Hunter, compiler, Report DOE/NV/14432-57, NTIS, U.S. Department of Commerce, 5285 Port Royal Road, Springfield, VA 22161. 377 pp. + apps. 
Moor, K.S. and W.G. Bradley. 1974. Ecological studies of vertebrates in plutonium contaminated areas of the Nevada Test Site. pp. 187-212 In: The Dynamics of Plutonium in Desert Environments. P.B. Dunaway and M.G. White, eds. NAEG/ERDA Report NVO-142, NTIS, U.S. Department of Commerce, 5285 Port Royal Road, Springfield, VA 22161. 369 pp.

Moor, K.S. and W.G. Bradley. 1987. Radioecology of small animal populations inhabiting nuclear-event site at Nevada Test Site. pp. 321-344 In: The Dynamics of Transuranics and Other Radionuclides in Natural

Environments. W.A. Howard and R.G. Fuller, eds. NVO-272, NTIS, U.S. Department of Commerce, 5285 Port Royal Road, Springfield, VA 22161565 pp.

Moor, K.S., W.G. Bradley, J.S. Miller, and S.R. Naegle. 1976. Standard Nevada Applied Ecology Group procedures for collection of small vertebrates from intensive study areas of NTS. pp. 139-148 In: Nevada Applied Ecology Group Procedures Handbook for Environmental Transuranics. M.G. White and P.B. Dunaway, eds. NAEG/ERDA Report NVO-166 (Volume 1 of 2), NTIS, U.S. Department of Commerce, 5285 Port Royal Road, Springfield, VA $22161322 \mathrm{pp}$.

Moor, W.G., S.R. Naegle, and W.G. Bradley. 1977. ${ }^{239} \mathrm{Pu}$ and ${ }^{241} \mathrm{Am}$ contamination of smal1 vertebrates in NAEG study areas of NTS and TTR. pp. 193-217 In: Environmental Plutonium on the Nevada Test Site and Environs. M.G. White, P.B. Dunaway, and W.A. Howard, eds. NAEG/ERDA Report NVO-171, NTIS, U.S. Department of Commerce, 5285 Port Royal Road, Springfield, VA $22161322 \mathrm{pp}$.

Moorefield, J. D. and T. A. Knight. 1991. Endangered, threatened, and sensitive vascular plants of Nevada. Nevada State Office of U. S. Bureau of Land Management, Reno, NV. $46 \mathrm{pp}$.

Munz, P.A. 1974. A flora of southern California. Univ. of California Press, Berkeley, CA. $1086 \mathrm{pp}$.

0'Farre17, M.J., W.A. Clark, F.H. Emerson, F.R. Kay, T.M. O'Farre11, and T. Okamoto. 1992. The use of mesh 1 ive traps for small mammals: are Sherman live traps deceptive? Poster presented at the 72nd Annual Meeting of the American Socjety of Mammalogists. 14-18 June 1992, University of Utah, Salt Lake City, UT. 
0'Farre11, T.P. and L.A. Emery. 1976. Ecology of the Nevada Test Site: A Narrative Summary and Annotated Bib7iography. USERDA Report NV0-169, NTIS, U.S. Department of Commerce, 5285 Port Royal Road, Springfield, VA 22161. $246 \mathrm{pp}$.

O'Farre17, T.P. and M. Sauls. 1987. Small mammals inhabiting nuclear event sites: population characteristics and radionuclide body burden. pp. 279-304 In: The Dynamics of Transuranics and Other Radionuclides in Natural Environments. W.A. Howard and R.G. Fuller, eds. NV0-272, NTIS, U.S. Department of Commerce, 5285 Port Royal Road, Springfield, VA 22161. $565 \mathrm{pp}$.

Pav7ik, B.M., D.I. Nickrent, and A.M. Howald. 1993. The recovery of an endangered plant. I. Creating a new population of Amsinckia grandiflora. Conservation Biology 7:510-526.

Pianka, E.R. 1986. Ecology and natural history of desert lizards. Analyses of the ecological niche and community structure. Princeton Univ. Press, Princeton, New Jersey, US. 208 pp.

Polis, G.A. and T. Yamashita. 1991. The ecology and importance of predaceous arthropods in desert communities. Pp. 180-222 In: The ecology of desert communities. G.A. Polis, editor. The Univ. of Arizona Press, Tucson, Arizona US. 456 pp.

Reichman, 0.J. 1991. Desert mammal communities. Pp. 311-347 In: The ecology of desert communities. G.A. Polis, editor. The Univ. of Arizona Press, Tucson, Arizona US. $456 \mathrm{pp}$.

Reichman, 0.J. and K.M. Van De Graaff. 1973. Seasonal activity and reproduction patterns of five species of Sonoran Desert rodents. Am. Midl. Nat. 90:118-126.

Reichman, 0.J. and K.M. Van De Graaff. 1975. Association between ingestion of green vegetation and desert rodent reproduction. $\mathrm{J}$. Mamma7 56:503-506.

Reynolds, R.T., J.M. Scott and R.A. Nussbaum. 1980. A variable circularplot method for estimating bird numbers. Condor 82:309-313.

Rhoads, W. A. and M. P. Williams. 1977. Status of endangered and threatened plant species on Nevada Test Site - a survey. Part 1: endangered species. Report EGG 1183-2356. Available from NTIS, 5285 Port Royal Road, Springfield, VA 22161. 102 pp. 
Ryser, F.A. 1985. Birds of the Great Basin. University of Nevada Press. Reno, NV. 604 pp.

Saethre, M.B. 1994. Trends in small mammals on the Nevada Test Site: 1989 through 1991. pp. $50-140+$ appe. In: Status of the Flora and Fauna on the Nevada Test Site, 1989 - 1991. R. Hunter, compiler, Report DOE/NV/14432-57, NTIS, U.S. Department of Commerce, 5285 Port Roya7 Road, Springfield, VA 22161. 337 pp. + apps.

Saethre, M.B. and P.A. Medica. 1992. Status of small mammals on the Nevada Test Site in 1988. pp. 97-160 In: Status of the Flora and Fauna on the Nevada Test Site: 1988. R.B. Hunter, compiler, Report DOE/NV/10630-29, NTIS, U.S. Department of Commerce, 5285 Port Royal Road, Springfield, VA 22161. $229 \mathrm{pp}$.

Scott, T.G. and C.H. Wasser. 1980. Checklist of North American plants for wildlife biologists. The Wildlife Society, 7101 Wisconsin Ave, Washington, D.C. 20014. $58 \mathrm{pp}$.

Szaro, R.C., and M.D. Jakle. 1985. Avian use of a desert riparian island and its adjacent scrub habitat. Condor 87:511-519.

Tanner, W.W. and C.D. Jorgensen. 1963. Reptiles of the Nevada Test Site. BYU Science Bul1., Biol. Ser 3:1-31.

Tueller, P.T. and V. Bostick. Joshua tree (Yucca brevifolia) biomass determinations. Unpublished manuscript in the BECAMP Tibrary. 23 pp.

Turner, F.B. (Coordinator). 1973. Rock Valley validation site report. U.S./IBP Desert Biome Reports of 1972 Progress, 'Vertebrates'. US/IBP Desert Biome Research Memo RM 73-2. Utah State Univ., Logan, UT. pp. 168-200.

Turner, F.B. (Coordinator). 1975. Rock Valley validation site report. Reports of 1974 Progress Volume 2: Validation Site Studies. US/IBP Desert Biome Research Memo RM 75-2. Utah State Univ., Logan, UT. 53 pp.

Turner, F.B. and McBrayer (eds.). 1974. Rock Valley validation site. U.S./IBP Desert Biome Research Memorandum 74-2. Utah State Univ., Logan, UT. 64 pp. 
Turner, F.B. and P.A. Medica. 1977. Sterility among female lizards (Uta stansburiana) exposed to continuous gamma radiation. Radiation Research 70:154-163.

Turner, F.B. and D.C. Randa11. 1989. Net production by shrubs and winter annuats in Southern Nevada. J. Arid Environ. 17:23-26.

Tyser, R.W. and C.A. Worley. 1992. Alien flora in grasslands adjacent to road and trail corridors in GTacier National Park, Montana (U.S.A.). Conservation Biology 6:253-262.

Van De Graaff, K.M. and R.P. Ba7da. 1973. Importance of green vegetation for reproduction in the kangaroo rat, Dipodomys merriami merriami. J. Mamma1. 54:509-512.

Vitt, L. 1991. Desert reptile communities. pp. 249-277 In: The ecology of desert communities. G.A. Polis, editor. The Univ. of Arizona Press, Tucson, Arizona, US. $346 \mathrm{pp}$.

Wilson, D.E. and D.M. Reeder, eds. 1993. Mammal Species of the World: A taxonomic and Geographic Reference. Washington, DC: Smithsonian Institution Press in association with the American Society of MammaTogists. Second Ed. 1206 pp.

Zar, J.H. 1984. Biostatistical Analysis. Second Edition. Prentice-Ha17, Inc. Englewood Cliffs, N.J. 718 pp. 


\section{APPENDIX A \\ MAMMALS OF THE NEVADA TEST SITE(1)}

Order INSECTIVORA: Insectivores

Family Soricidae: Shrews

Notiosorex crawfordi $i$

Sorex merriami

Desert shrew

Merriam's shrew

Sorex tene77us

Inyo shrew

$\mathrm{DAF}^{(2)}$

Present/Absent

?

A

A

Order CHIROPTERA: Bats

Family Vespertilionidae: Vespertilionid bats

Antrozous pallidus

Eptesicus fuscus

Euderma maculatum ${ }^{(3)}$

Lasionycteris noctivagans

Lasiurus cinereus

Myotis californicus

Myotis evotis

Myotis thysanonodes

Myotis volans

Pipistrel7us hesperus

Plecotus townsendi $i$
Pal1 id bat

Big brown bat

Spotted bat

SiTver-haired bat

Hoary bat

California myotis

Long-eared myotis

Fringed myotis

Long-legged myotis

Western pipistrelle

Townsend's big-eared bat

$\mathrm{p}$
$?$
$?$
$\mathrm{p}$
$?$
$?$
$?$
$?$
$?$
$\mathrm{p}$
$\mathrm{p}$

Family Molossidae: Free-tailed bats

Tadarida brasiliensis

Mexican free-tail bat

?

Order CARNIVORA: Carnivores

Fami7y Canidae: Coyotes and foxes

Canis Tatrans

Urocyon cinereoargenteus

Vulpes velox [=macrotis]

$\begin{array}{ll}\text { Coyote } & \text { P } \\ \text { Gray fox } & ? \\ \text { Kit fox } & \text { P }\end{array}$

\footnotetext{
(1) Nomenclature from Wilson and Reeder 1993, List is compiled from 0'Farrell and Emery 1976, Jorgensen and Hayward 1965, Medica 1990, and EG\&G/EM 1992, 1993.

${ }^{(2)} \mathrm{P}=$ present by trapping or sign (tracks, scats or burrows), $\mathrm{p}=$ present by habitat type, $A=$ absent by habitat, ? = status unknown.

${ }^{(3)}$ Vocalization evidence onTy (EG\&G/EM 1993).
} 
Family Procyonidae: Procyonids

Bassariscus astutus Ringtail p

Family Mustelidae: Mustelids

Mustela frenata Long-tailed weasel ?

Taxidea taxus Badger $\mathrm{p}$

Spilogale putorius [=gracilis] Western spotted skunk A

Family Felidae: Cats

Felis concolor

Cougar

Bobcat

$p$

Lynx rufus A 
Family Geomyidae: Pocket gophers

Thomomys bottae

Botta's pocket gopher

P

Family Heteromyidae: Heteromyid rodents

Chaetodipus formosus

Dipodomys deserti

Dipodomys merriami

Long-tailed pocket mouse $P$

Desert kangaroo rat $p$

Merriam's kangaroo rat $P$

Dipodomys microps

Chise1-toothed kangaroo rat $P$

Dipodomys ordij

Ord's kangaroo rat

Microdipodops megacephalus

Perognathus longimembris

Dark kangaroo mouse

Little pocket mouse

Perognathus parvus

Great Basin pocket mouse

A

$P$

$\mathrm{p}$

Family Muridae: Rats, mice, and voles

Lemmiscus [=Lagurus] curtatus

Neotoma lepida

Sagebrush vole A

Onychomys torridus

Desert woodrat

$P$

Southern grasshopper mouse P

Peromyscus crinitus

Canyon mouse

A

Peromyscus eremicus

Cactus mouse

$P$

Deer mouse $P$

Peromyscus maniculatus

Pinyon mouse

Peromyscus truei
Reithrodontomys megalotis

Western harvest mouse

A

$\mathrm{p}$

Family Erethizontidae: New World porcupines

Erethizon dorsatum

Porcupine

A

Order LAGOMORPHA: Lagomorphs

Family Leporidae: Hares and rabbits

Lepus californicus

Sylvilagus auduboni $i$

Black-tailed jackrabbit

Desert cottontail

Sylvilagus nuttal7ii

Nuttall's cottontail

$P$

$P$

A 


\section{APPENDIX B}

\section{EPHEMERAL PLANT SPECIES IN AREAS SURROUNDING}

\section{THE DEVICE ASSEMBLY FACILITY}

(Letters following each name indicate the study sites a species was found at; $A=$ vicinity of the paved access road; $B=b l$ aded, graveled area west of the DAF; $C=$ undisturbed area north of the dike; $D=$ area near water tank.) ${ }^{i}=$ introduced species.

Amsinckia tessellata

Location

Antirrhinum filipes

Astragalus acutirostris

$A B C D$

Astragalus lentiginosus fremontii

$A$

$A C D$

Bromus rubens ${ }^{i}$

$A B C D$

$A B C D$

Bromus tectorum ${ }^{i}$

Camissonia boothii

$A B D$

Camissonia brevipes

$A$

Camissonia claviformis

Camissonia kernensis

$A B C D$

Camissonia munzii

$A D$

$B D$

Camissonia pterosperma

A

D

Camissonia refracta

D

Caulanthus cooperi

$A D$

Caulanthus 7asiophy7lus

$A B C D$

Chaenactis carphoclinia

$A B C D$

Chaenactis fremonti $i$

$A B$

Chaenactis macrantha

$B$

Chaenactis stevioides

Chenopodium incanum

$A B C D$

$D$

Chorizanthe brevicornu

ABD

Chorizanthe rigida

Chorizanthe thurberi

A

A

Cryptantha circumscissa

$A B C D$

Cryptantha dumetorum

$B D$

Cryptantha gracilis

$A D$

Cryptantha micrantha

$A D$

Cryptantha nevadensis

$A B C D$

Cryptantha pterocarya

$A B C D$

Cryptantha recurvata

$A D$

Delphinium parishii

$A C$

Descurainia pinnata

Descurainia sophia ${ }^{i}$

$A B C D$

$A C D$ 


\begin{tabular}{|c|c|}
\hline Eriogonum deflexum & $A B C D$ \\
\hline Eriogonum inflatum & $A B C D$ \\
\hline Eriogonum maculatum & $A B D$ \\
\hline Eriogonum nidularium & $A B C D$ \\
\hline Eriogonum reniforme & B \\
\hline Eriogonum trichopes & $A B C D$ \\
\hline Eriophyl7um wa7lacei & B \\
\hline Erodium cicutarium ${ }^{i}$ & $A B D$ \\
\hline Eschscholzia glyptosperma & $A B C D$ \\
\hline Eschscholzia minutiflora & $\mathrm{D}$ \\
\hline Eucrypta micrantha & $A B$ \\
\hline Euphorbia albomarginata & C \\
\hline Gilia cana & D \\
\hline GiTia filiformis & D \\
\hline Gilia sinuata & $A B D$ \\
\hline Gilia transmontana & $A B C D$ \\
\hline Halogeton glomeratus ${ }^{i}$ & $A B$ \\
\hline Ipomopsis polycladon & $A B C D$ \\
\hline Langloisia schottii & $A$ \\
\hline Langloisia setosissima & $A$ \\
\hline Lepidium 7asiocarpum & $A B C D$ \\
\hline Linanthus arenicola & $\mathrm{D}$ \\
\hline Linanthus demissus & $A B D$ \\
\hline Linanthus dichotomus & $A B D$ \\
\hline Linanthus jonesij & $A$ \\
\hline Lotus humistratus & $C D$ \\
\hline Lupinus flavoculatus & $C D$ \\
\hline Lupinus shockleyi & $A B C D$ \\
\hline Machaeranthera canescens & $A D$ \\
\hline Malacothrix glabrata & $A B C D$ \\
\hline Malacothrix sonchoides & $A D$ \\
\hline Mentzelia albicaulis & $A B C D$ \\
\hline Mimulus bigelovij & B \\
\hline Mirabilis bigelovii & C \\
\hline Monoptilon belliodes & $A D$ \\
\hline Nama aretoides & A \\
\hline Nama demissum & $A B C D$ \\
\hline Nama pusil7um & ABD \\
\hline Nemacladus g7anduliferus & $A B C D$ \\
\hline oxytheca perfoliata & A \\
\hline Pectocarya heterocarpa & $A D$ \\
\hline Pectocarya platycarpa & $A B C D$ \\
\hline Pectocarya setosa & A \\
\hline Phacelia crenulata & $A$ \\
\hline
\end{tabular}

Appendix B - 120 
Phacelia fremontii

Phacelia parishii

Phacelia vallis-mortae

Prenanthella exigua

Rafinesquia neomexicana

Sa7so7a austra7is*

Schismus arabicus*

Sisymbrium altissimum*

Stephanomeria exigua

Stephanomeria pauciflora

Streptanthe77a 7ongirostris

Usti7ago bul7ata*

(smut on $B$. rubens)

Vulpia octoflora

Total $=89$ plant species plus one fungus. Several may live more than one year, (e.g., Atragalus 7entiginosus fremontii, Stephanomeria pauciflora, Mimu7us bigelovii, Delphinium parishii).

Notable missing species include Eriophyl7um pringlei, Mirabilis pudica, Ani socoma acaulis, Astragalus didymocarpus, Eriastrum eremicum.
$A B C D$

$B$

$A B C D$

$A B$

$A B C$

$A B D$

$A B D$

AC

A

A

$A B$

ABD

$A B C D$ 


\section{APPENDIX C}

\section{EPHEMERAL PLANTS}

Tables below show properties of ephemeral plant plots determined with 10 (DAF3) or $20,0.025 \mathrm{~m}^{2}$ quadrats. Plot locations are in text Table 2. Species found outside the 20 quadrats are listed in Appendix B. Abbreviations are the first three letters of the genus and species combined, and may be determined from Appendix B.

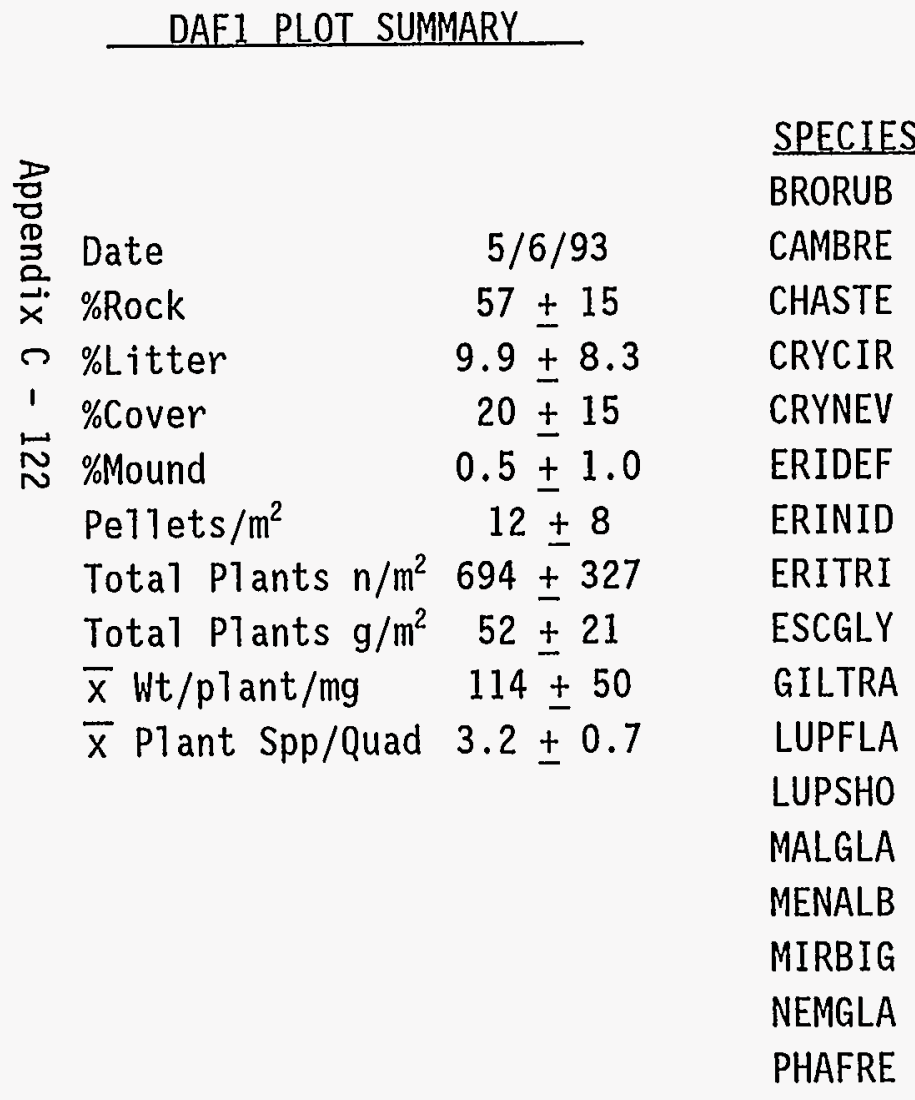

\begin{tabular}{cccc}
\multicolumn{3}{c}{ SPECIES PROPERTIES $( \pm 2$ se $)$} & \\
\cline { 1 - 2 }$\frac{n / \mathrm{m}^{2}}{280 \pm 167}$ & $\frac{\mathrm{g} / \mathrm{m}^{2}}{34 \pm 16}$ & $\frac{\mathrm{mg} / \mathrm{plant}}{152 \pm 66}$ & \% reproductive \\
$4 \pm 6$ & $0.19 \pm 0.27$ & $48 \pm 10$ & $100 \pm 0$ \\
$8 \pm 12$ & $0.16 \pm 0.28$ & $18 \pm 11$ & $50 \pm 100$ \\
$4 \pm 6$ & $0.05 \pm 0.08$ & $13 \pm 7$ & $100 \pm 0$ \\
$2 \pm 4$ & $0.7 \pm 1.4$ & 369 & $100 \pm 0$ \\
$8 \pm 9$ & $0.09 \pm 0.10$ & $12 \pm 3$ & 100 \\
$4 \pm 6$ & $0.03 \pm 0.05$ & $8 \pm 7$ & $0 \pm 0$ \\
$4 \pm 6$ & $0.04 \pm 0.06$ & $10 \pm 12$ & $0 \pm 0$ \\
$24 \pm 26$ & $0.32 \pm 0.34$ & $16 \pm 8$ & $50 \pm 100$ \\
$4 \pm 6$ & $0.6 \pm 1.1$ & $156 \pm 261$ & $100 \pm 0$ \\
$22 \pm 24$ & $8 \pm 8$ & $567 \pm 527$ & $100 \pm 0$ \\
$4 \pm 6$ & $0.05 \pm 0.10$ & 25 & $67 \pm 39$ \\
$2 \pm 4$ & $0.26 \pm 0.53$ & 132 & $50 \pm 100$ \\
$14 \pm 10$ & $1.1 \pm 1.0$ & $79 \pm 61$ & 100 \\
$2 \pm 4$ & $0.27 \pm 0.54$ & 135 & $100 \pm 0$ \\
$6 \pm 9$ & $0.02 \pm 0.03$ & $4 \pm 6$ & 100 \\
$302 \pm 242$ & $7.3 \pm 4.1$ & $48 \pm 32$ & $75 \pm 50$ \\
& \pm 2 & $97 \pm 7$
\end{tabular}




\section{reproductive}

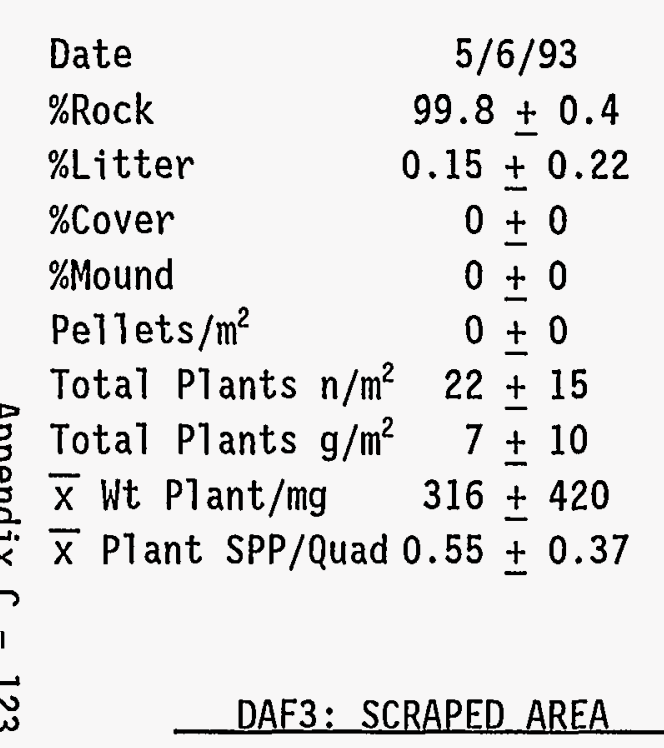

\section{SPECIES}

\section{BRORUB}

CHASTE

PHAFRE

SALAUS

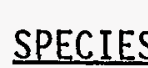

BRORUB

Date

\%Rock $4 / 20 / 93$

\%Litter

\%Cover

\%Mound

Pellets $/ \mathrm{m}^{2}$ $62 \pm 6$

$2.7 \pm 1.3$

$0 \pm 0$

$0 \pm 0$

$4 \pm 8$

Total Plants $n / m^{2} 1968 \pm 732$

Total Plants $\mathrm{g} / \mathrm{m}^{2} 9.3 \pm 3.1$

$\bar{x}$ Wt Plants/mg $9.6 \pm 5.5$

$\bar{X}$ Plant Spp/Quad $1.4 \pm 0.3$

ERIDEF

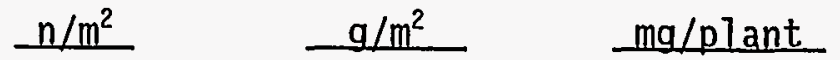

$\%$

$\begin{array}{lccc}4 \pm 6 & 0.35 \pm 0.66 & 88 \pm 153 & 100 \pm 0 \\ 2 \pm 4 & 0.42 \pm 0.83 & 208 & 100 \\ 8 \pm 7 & 5.3 \pm 9.6 & 665 \pm 1158 & 100 \pm 0 \\ 8 \pm 7 & 0.87 \pm 1.21 & 109 \pm 129 & 25 \pm 50\end{array}$

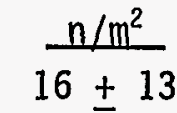

$1952 \pm 728$ $\frac{\mathrm{g} / \mathrm{m}^{2}}{0.34 \pm 0.34}$

$9.0 \pm 3.0$ $\mathrm{mg} / \mathrm{plant}$

$21 \pm 14$

$5.0 \pm 1.5$
$\%$ reproductive

$100 \pm 0$ 
SPECIES PROPERTIES $(+2$ Se)

\begin{tabular}{|c|c|c|c|c|c|c|c|}
\hline \multirow{2}{*}{\multicolumn{8}{|c|}{$\mathrm{mg} / \mathrm{plant}$}} \\
\hline & & & & & & & \\
\hline & & & BRORUB & $336 \pm 496$ & $9.7 \pm 10.2$ & $46 \pm 34$ & $94 \pm 13$ \\
\hline & Date & $4 / 20 / 93$ & CAMCLA & $4 \pm 8$ & $0.03 \pm 0.06$ & $\overline{7}$ & 100 \\
\hline & \%Rock & $46 \pm 13$ & CHOBRE & $4 \pm 8$ & $0.016 \pm 0.033$ & 4 & 100 \\
\hline & $\%$ Litter & $22 \pm 16$ & CRYNEV & $4 \pm 8$ & $0.03 \pm 0.06$ & 8 & 100 \\
\hline & $\%$ Cover & $15 \pm 20$ & ERIDEF & $1260 \pm 372$ & $14 \pm 7$ & $13 \pm 7$ & $0 \pm 0$ \\
\hline & $\%$ Mound & $1.3 \pm 2.6$ & GILTRA & $4 \pm 8$ & $0.23 \pm 0.46$ & $5 \overline{8}$ & 100 \\
\hline \multirow{3}{*}{$\begin{array}{l}\frac{D}{8} \\
\frac{D}{0} \\
\frac{\partial}{\vec{a}} \\
\vec{x} .\end{array}$} & Pellets $/ \mathrm{m}^{2}$ & $28 \pm 48$ & IPOPOL & $4 \pm 8$ & $0.05 \pm 0.10$ & 12 & 100 \\
\hline & & & PHAFRE & $20 \pm 32$ & $0.22 \pm 0.35$ & $10 \pm 1$ & $100 \pm 0$ \\
\hline & Total Plants $\mathrm{n} / \mathrm{m}^{2}$ & $1652 \pm 768$ & VULOCT & $16 \pm 24$ & $0.15 \pm 0.20$ & $13 \pm 14$ & $100 \pm 0$ \\
\hline 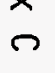 & Total Plants $\mathrm{g} / \mathrm{m}^{2}$ & $25 \pm 11$ & & & & & \\
\hline 1 & $\bar{x}$ Wt Plant/mg & $24 \pm 12$ & & & & & \\
\hline & $\bar{X}$ Plant Spp/Quad & $2.7 \pm 0.7$ & & & & & \\
\hline
\end{tabular}




\begin{tabular}{|c|c|c|c|c|c|c|}
\hline & & SPECIES & $n / m^{2}$ & $\mathrm{~g} / \mathrm{m}^{2}$ & $\mathrm{mg} / \mathrm{plant}$ & $\%$ reproductive \\
\hline & & BRORUB & $468 \pm 373$ & $32 \pm 25$ & $67 \pm 21$ & $100 \pm 0$ \\
\hline Date & $4 / 21 / 93$ & CHACAR & $12 \pm 17$ & $0.35 \pm 0.58$ & $26 \pm 20$ & $50 \pm 100$ \\
\hline \%Rock & $54 \pm 16$ & CRYNEV & $8 \pm 16$ & $0.22 \pm 0.44$ & 27 & 100 \\
\hline \%Litter & $19 \pm 13$ & ERIDEF & $8 \pm 16$ & $0.15 \pm 0.30$ & 19 & 0 \\
\hline$\%$ Cover & $48 \pm 30$ & ERINID & $8 \pm 11$ & $0.12 \pm 0.16$ & $14 \pm 7$ & $0 \pm 0$ \\
\hline \%Mound & $11 \pm 18$ & ERIPRI & $4 \pm 8$ & $0.06 \pm 0.12$ & 15 & 0 \\
\hline Pellets $/ \mathrm{m}^{2}$ & $0 \pm 0$ & ERIPUL & $8 \pm 16$ & $0.4 \pm 0.8$ & 50 & 100 \\
\hline & & GILTRA & $12 \pm 12$ & $0.55 \pm 0.57$ & $46 \pm 10$ & $100 \pm 0$ \\
\hline Total Plants $\mathrm{n} / \mathrm{m}^{2}$ & $560 \pm 395$ & LUPFLA & $4 \pm 8$ & $3.6 \pm 7.3$ & $9 \overline{00}$ & $10 \overline{0}$ \\
\hline 艾 Total Plants $\mathrm{g} / \mathrm{m}^{2}$ & $40 \pm 26$ & LUPSHO & $4 \pm 8$ & $0.8 \pm 1.6$ & 195 & 100 \\
\hline$\sigma \bar{x}$ Wt Plant/mg & $89 \pm 67$ & PHAFRE & $20 \pm 18$ & $1.7 \pm 1.8$ & $76 \pm 35$ & $100 \pm 0$ \\
\hline 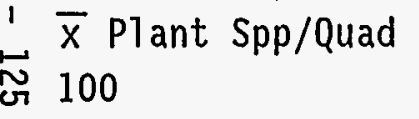 & $2.6 \pm 1.0$ & VULOCT & $4 \pm 8$ & $0.22 \pm 0.43$ & $\overline{5} 4$ & \\
\hline
\end{tabular}




\section{APPENDIX - D \\ BIRD LIST FOR THE DEVICE ASSEMBLY FACILITY AREA $61993^{(5)}$}

CLASS AVES:BIRDS

$\underline{\text { Status }}^{(6)}$

Order Ciconiformes: Herons, Ibises, and Storks

Family Ardeidae: Herons, Egrets, and Bitterns Egretta thuta............... Snowy Egret

$M, S$

Order Anseriformes: Waterfow7

Family Anatidae: Swans, Geese, and Ducks

Anas crecca................... Green-winged Teat M, S

Anas cyanoptera...............Cinnamon Teal M, S

Order Falconiformes: Diurnal Birds of Prey

Fami 1 y Accipitridae: Hawks, Kites, and Eagles

Subfamity Pandioninae: Ospreys

Pandion haliaetus............. osprey

M

Subfamily Accipitrinae: Kites, Hawks, Eagles, and Harriers

Aquila chrysaetos..............Golden Eagle PR

Buteo jamaicensis............... Red-tailed Hawk PR,S

Buteo swainsoni............... Swainson's Hawk M

Family Falconidae: Falcons and Caracaras

Falco mexicanus.................Prairie Fatcon

$\mathrm{PR}, \mathrm{S}$

Falco sparverius.

American Kestrel

$\mathrm{PR}$,

${ }^{(5)}$ Nomenclature follows Banks et a1. (1987)

${ }^{(6)}$ Status: $S=$ observed at DAF sewage pond; $B=$ breeds near DAF; $S R=$ Summer resident near DAF; $P R=$ Permanent resident in or near DAF region; $M=$ Spring-fa 11 migrant. 
Order Galliformes: Gallinaceous Birds

Family Phasianidae: Pheasants, Grouse, and Quail

Subfamily Phasianinae: Partridges, Francolins, and Pheasants

Alectoris chukar...............Chukar

$\mathrm{PR}, \mathrm{B}$

Order Charadriformes: Shorebirds, Gulls, and Alcids

Family Charadrijdae: Plovers

Charadrius vociferus............Killdeer M, S

Family Recurvirostridae: Avocets and Stilts

Recurvirostra americana.........American Avocet M,S

Family Scolopacidae: Sandpipers and Allies

Subfamily Scolopacinae: Sandpipers, Turnstones, Surfbirds and Snipes Actitis macuTaria.............. Spotted Sandpiper M,S

Calidris mauri................Western Sandpiper M,

Calidris minuti7la............. Least Sandpiper M,S

Catoptrophorus semipalmatus.....Willet M,S

Ga77inago ga77inago............Common Snipe M,S

Numenius americanus.............Long-billed Curlew M

Order Columbiformes: Pigeons and Alties

Famity Columbidae: Pigeons and Doves

Zenaida macroura..............Mourning Dove SR, B,S

Order Strigiformes: Ow7s

Family Tytonidae: Barn-owls

Tyto a 7 ba...................Common Barn-OwT PR,S

Family Strigidae: Typical Ow7s

Athene cunicularia.............Burrowing 0w1 PR, B

Order Caprimulgiformes: Goatsuckers and A7Ties 
Family Caprimulgidae: Nightjars

Chordeiles acutipennis.......... Lesser Nighthawk

$S R$

Order Apodiformes: Swifts and Hummingbirds

Family Trochilidae: Hummingbirds

.......................... Hid. Humingbird

M

Order Piciformes: Woodpeckers and Allies

Family Picidae: Woodpeckers and Wrynecks

Picoides scalaris..............Ladder-backed Woodpecker

$S R$

Order Passeriformes: Perching Birds

Family Tyrannidae: Tyrant Flycatchers

Subfamily Fluvicolinae: Fluvicoline Flycatchers

Sayornis saya............... Say's Phoebe

$S R, B, S$

Subfamily Tyranninae: Kingbirds and Allies

Myiarchus cinerascens...........Ash-throated Flycatcher

$S R B, S$

Tyrannus verticalis............ Western Kingbird

$S R, B, S$

Family A7audidae: Larks

Eremophila alpestris...........Horned Lark PR, S

Family Hirundinidae: Swallows

Hirundo pyrrhonota.............Cliff Swallow M,S

Hirundo rustica ................Barn Swallow M,S

Stelgidopteryx serripennis....... Northern Rough-winged Swallow M,S

Tachycineta thalassina.........Violet-green Swallow M,S

Family Corvidae: Jays, Magpies, and Crows

Corvus corax.................. Common Raven

Gymnorhinus cyanocepha7us........ Pinyon Jay

PR,S

$M$

Family Troglodytidae

Campylorhynchus brunneicapi77us..Cactus Wren

SR 
Order Passeriformes: (cont.)

Family Muscicapidae: 01d World Flycatchers and Allies

Subfamily Turdinae: Thrushes

Sialia currucoides.............Mountain Bluebird

Family Mimidae: Mockingbirds and Thrashers

Mimus polyglottos................Northern Mockingbird

$S R, B$

Oreoscoptes montanus............Sage Thrasher

Family Motacil7idae: Wagtails and Pipits

Anthus rubescens...............American Pipit

M,S

Family Laniidae: Shrikes

Lanius 7udovicianus............. Loggerhead Shrike

$S R, B$

Family Sturnidae: Starlings

Subfamily: Sturninae

Sturnus vulgaris..............European Starling PR,S

Family Emberizidae: Emberizid Finches and Al7ies

Subfamily Parul inae: Wood-Warblers

Dendroica coronata............. Yellow-rumped Warbler

$\mathrm{M}, \mathrm{S}$

Subfamity Cardinalinae: CardinaT-Grosbeaks

Pheucticus me7anocepha7us.......Black-headed Grosbeak

M

Subfamily Emberizinae: American Sparrows and Towhees

Amphispiza be $77 i \ldots . . . \ldots$...... Sage Sparrow

Amphispiza bilineata...........Black-throated Sparrow

$M, S$

Melospiza melodia.............. Song Sparrow

$S R, B, S$

Spize77a breweri................Brewer's Sparrow

$M, S$

Zonotrichia 7eucophrys...........White-crowned Sparrow

$S R, B, S$

$M, S$

Subfamily Icterinae: American Blackbirds and Orioles

Age7aius phoeniceus............ Red-winged B7ackbird

$M, S$

Icterus parisorum.............. Scott's Oriole

$S R, B$

Molothrus ater.

.Brown-headed Cowbird

$S R, S$ 
Order Passeriformes: (cont.)

Quiscalus mexicanus............Great-tailed Grackle SR,S Sturne77a neglecta.............Western Meadowlark M,S

Family Fringillidae: 01d World Finches and A17ies

Subfamity Carduelinae: Cardueline Finches

Carduelis psaltria............. Lesser Goldfinch M,S

Carduelis tristis...............American Goldfinch M,S

Carpodacus mexicanus............ House Finch PR, B, $S$

Family Passeridae: 01d World Sparrows

Passer domesticus............. House Sparrow PR, B, S 


\section{DISTRIBUTION LIST FOR BECAMP/ECOLOGY \\ DAF REPORTS}

Number of Copies

1. THOMAS L. ACKERMAN

528 Kendall Avenue, Apt. 5

Palo A7to, CA 94306

2. BECAMP LIBRARY

M/S 740

Mercury, NV 89023

3. BRIGHAM YOUNG UNIVERSITY LIBRARY

Exchange Section

Provo, UT 84601

4. CHARLES D. CANHAM

Institute of Ecosystem Studies

The New York Botanical Garden

Mary Flagler Gary Arboretum

Box AB

Millbrook, NY 12545

5. DR. WALTER H. CONLEY

Department of Biology

New Mexico State University

Las Cruces, NM 88003

6. DR. STEVE CORN

U.S. Department of Interior

Fish and Wildlife Service

4512 McMurray Avenue

Fort Collins, CO 80525-3400

7. DEATH VALLEY NATIONAL MONUMENT 1

Library

Death Valley, CA 92328 


\section{DISTRIBUTION LIST FOR BECAMP/ECOLOGY \\ DAF REPORTS}

8. JOHN DONALDSON, REGIONAL MANAGER 2

Nevada Department of WiTd7ife

Region III

State Mailroom Complex

Las Vegas, NV 89158

9. DR. CHARLES L. DOUGLAS

Department of Biological Sciences

University of Nevada Las Vegas

4505 South Maryland Parkway

Las Vegas, NV 89154

10. DONALD R. ELLE, Ph.D., DIRECTOR

Environmental Protection Division

DOE Nevada Field Office

P. 0. Box 98518, M/S 505

Las Vegas, NV 89193-8518

11. TODD ESQUE

National Biological Service

C/O BLM Dixie Research Area

$225 \mathrm{~N}$. Bluff Street

St. George, UT 84770

12. DR. EDWARD H. ESSINGTON

Los Alamos National Laboratory

Environmental Science Group

HSE 12

Los Alamos, NM 87545

13. DR. FRED FERATE

Analytical Services Department

Reynolds Electrical \& Engineering Co., Inc.

P. O. Box 98521 , M/S 776

Las Vegas, NV 89193-8521

14. ROBERT E. FRIEDRICHS

U. S. Department of Energy

Nevada Operations Office

P. 0. Box 98518 , M/S 505

Las Vegas, NV 89193-8518 


\section{DISTRIBUTION LIST FOR BECAMP/ECOLOGY \\ DAF REPORTS}

15. BERT FRIESEN 1

Raytheon Services Nevada

P. 0. Box $98518, M / S 605$

Las Vegas, NV 89193-5487

16. ROBERT FURLOW

DOE Nevada Field Office

P. 0. Box $98518, M / S 505$

Las Vegas, NV 89193-8518

17. DR. THOMAS H. FRITTS

U. S. Fish and Wildlife Service

National Museum of Natural History

Smithsonian Institution

Washington DC 20560

18. DR. RICHARD 0. GILBERT

Battelle

Pacific Northwest Laboratories

P. 0. Box 999

Rich7and, WA 99352

19. WAYNE GLINES

Environmental Information Center

REECO

P. 0. Box $98521, M / S 428$

Las Vegas, NV 89193-8521

20. GLOBAL ENVIRONMENTAL MONITORING SYSTEM 1

P. 0. Box 30552

Nairobi, Kenya

21. RON GREEN

EG\&G/EM

P. 0. Box 1912, M/S 570/V-01

Las Vegas, NV 89125 


\section{DISTRIBUTION LIST FOR BECAMP/ECOLOGY \\ DAF REPORTS}

22. PAUL GREGER 1

$E G \& G / E M$

P. 0. Box 1912, M/S 570/V-01

Las Vegas, NV 89125

23. ROSS HALEY

Nevada Department of Wildlife

4747 Vegas Drive

Las Vegas, NV 89158

24. MIKE HESS, ACTING CHIEF

Game Division

Nevada Department of Wildlife

1100 Valley Road

P. 0. Box 10678

Reno, NV 89520

25. DR. HOWARD HAWTHORNE

REECo

P. 0. Box $98521, M / S 459$

Las Vegas, NV 89193-8521

26. DR. RICHARD HUNTER

EG\&G/EM

P. 0. Box 1912, M/S 570/V-01

Las Vegas, NV 89125

27. DR. CLIVE D. JORGENSEN

Brigham Young University

Department of Zoology

574 Widtsoe Building

Provo, UT 84602

28. DR. TERI A. KNIGHT

Nevada Heritage Program

Barrick Museum of Natural History

University of Nevada Las Vegas

4505 South Maryland Parkway

Las Vegas, NV 89154 


\section{DISTRIBUTION LIST FOR BECAMP/ECOLOGY}

DAF REPORTS

29. ALAN R. LATHAM

Analytical Services Department

P. 0. Box 98521, M/S 708

Las Vegas, NV 89193-8521

30. JOHN M. MCGRAIL

U. S. Department of Energy

NTSO, M/S 701

Mercury, NV 89023

31. PHILIP A. MEDICA

U. S. Department of Interior

National Biological Survey

P. 0. Box 26569

Las Vegas, NV 89126

32. STEPHEN A. MELLINGTON

DOE Nevada Field Office

P. 0. Box 98518, M/S 505

Las Vegas, NV 89193-8518

33. DR. WESLEY E. NILES

Department of Biological Sciences

University of Nevada Las Vegas

4505 South Maryland Parkway

Las Vegas, NV 89154

34. DR. THOMAS P. O'FARRELL

EG\&G/EM

511 Avenue $H$

Boulder City, NV 89005

35. DR. JOHN OLDEMEYER

National Ecology Research Center

4512 McMurray Avenue

Ft. Collins, CO 80525-3400

36. KENT OSTLER

EG\&G/EM

P. 0. Box 1912, M/S 570/V-01

Las Vegas, NV 89125 


\section{DISTRIBUTION LIST FOR BECAMP/ECOLOGY \\ DAF REPORTS}

37. SUSAN PECK

EAD

USEPA Environmental Systems Monitoring Lab

P. 0. Box 93478

Las Vegas, NV 89193-3478

38. DR. LONNIE C. PIPPIN

Desert Research Institute

Social Sciences Center

P. 0. Box 60220

Reno, NV 89506

39. DAVID RABROCK

Special Collections Library

University of Nevada Las Vegas

4505 Maryland Parkway

Las Vegas, NV 89154

40. DANIEL RAKESTRAW

$E G \& G / E M$

P. 0. Box 1912, M/S 570/V-01

Las Vegas, NV 89125

41. DR. W. H. RICKARD

1904 Lassen Avenue

Richland, WA 99352

42. DR. EVAN M. ROMNEY

1736 East Gary Street

Mesa, AZ 85203

43. EDWARD F. RUCKER

U. S. Department of Energy

NTS Area 6, M/S 219

44. MARY SAETHRE

$E G \& G / E M$

P. 0. Box 1912, M/S 570/V-01

Las Vegas, NV 89125 


\section{DISTRIBUTION LIST FOR BECAMP/ECOLOGY \\ DAF REPORTS}

45. TERRY SEXSON 1

U. S. Department of Interior

Fish and Wildiife Service

Office of Information Transfer

1025 Pennock P1ace, Suite 212

Fort Collins, CO 80524

46. SID SLOAN 1

Bureau of Land Management

P. 0. Box 26529

Las Vegas, NV 89126

47. L. S. SYGITOWICZ 1

REECo

Environmental Management Division

P. 0. Box $98521, M / S 612$

Las Vegas, NV $89193-8521$

48. UNITED NATIONS ENVIRONMENT PROGRAMME 1

P. 0. Box 30552

Nairobi, Kenya

49. UNIVERSITY OF NEVADA LAS VEGAS 1

Merrill Library

4505 South Maryland Parkway

Las Vegas, NV 89154

50. U. S. BUREAU OF LAND MANAGEMENT 1

District Manager Las Vegas District Office

P. 0. Box 26569

Las Vegas, NV 89126

51. U. S. DEPARTMENT OF ENERGY

Nevada Field Office Library

P. 0. Box 98518, M/S 505

Las Vegas, NV 89193-8518 


\section{DISTRIBUTION LIST FOR BECAMP/ECOLOGY \\ DAF REPORTS}

52. DR. LAWRENCE R. WALKER 1

Department of Biological Sciences

University of Nevada Las Vegas

4505 Maryland Parkway

Las Vegas, NV 89154-4004

53. CATHY WILLS 1

EG\&G/EM

P. 0. Box 1912, M/S 570/V-01

Las Vegas, NV 89125

54. DR. BRUCE D. WOODWARD 2

$E G \& G / E M$

P. 0. Box 1912, M/S 570/V-01

Las Vegas, NV 89125

55. BARBARA YOERG 1

DOE/NTSO

$\mathrm{M} / \mathrm{S} 701$ 